ELIZABETH RODRIGUES RANGEL RORIZ

RECICLAGEM DE PILHAS: RECUPERAÇÃO DO MANGANÊS NA FORMA DE DIÓXIDO DE MANGANÊS ELETROLÍTICO

São Paulo 
ELIZABETH RODRIGUES RANGEL RORIZ

\title{
RECICLAGEM DE PILHAS: RECUPERAÇÃO DO MANGANÊS NA FORMA DE DIÓXIDO DE MANGANÊS ELETROLÍTICO
}

\author{
Dissertação apresentada à Escola \\ Politécnica da Universidade de São \\ Paulo para obtenção do título de \\ Mestre em Engenharia \\ Área de Concentração: Engenharia \\ Metalúrgica e de Materiais \\ Orientador: Prof. Titular \\ Jorge Alberto Soares Tenório
}

São Paulo 
Este exemplar foi revisado e alterado em relação à versão original, sob responsabilidade única do autor e com a anuência de seu orientador.

São Paulo, de janeiro de 2010.

Assinatura do autor

Assinatura do orientador

\section{FICHA CATALOGRÁFICA}

Roriz, Elizabeth Rodrigues Rangel

Reciclagem de pilas: recuperação do manganês na forma de dióxido de manganês eletrolítico / E.R.R. Roriz. -- ed.rev. -- São Paulo, 2010.

$82 \mathrm{p}$.

Dissertação (Mestrado) - Escola Politécnica da Universidade de São Paulo. Departamento de Engenharia Metalúrgica e de Materiais.

1. Reciclagem de resíduos urbanos 2. Manganês 3 . Eletrodeposição I. Universidade de São Paulo. Escola Politécnica.

Departamento de Engenharia Metalúrgica e de Materiais II. t. 
Ao meu marido João Carlos pelo apoio irrestrito em todos os momentos.

Ao meu filho Bruno que soube tão bem compreender os meus momentos de ausência em função deste trabalho. 


\section{AGRADECIMENTOS}

A Deus por guiar o meu caminho e me confortar nas horas difíceis.

Ao Prof. Dr. Jorge Alberto Soares Tenório pela orientação.

Ao Prof. Paulo Von Krüger da Escola de Minas de Ouro Preto pelos comentários e sugestões.

À Prof. Dra. Denise Crocce Romano Espinosa pelas sugestões apresentadas no exame de Qualificação.

Ao Prof. Dr. Douglas Gouvea do Laboratório de Processos Cerâmicos pela realização das análises de áreas superficiais específicas.

Ao Prof. Dr. Henrique Khan do Laboratório de Caracterização Tecnológica pela realização das análises de fluorescência de raios- $X$ e de difração de raios- $X$.

Ao Prof. Dr. André Paulo Tschiptschin do Laboratório de Microscopia de Eletrônica e de Força atômica pela utilização do microscópio eletrônico.

Ao amigo José Marcos pela ajuda na realização dos ensaios de análise superficial específica.

Aos amigos Ricardo, Vilmário, Eduardo e Victor pelo auxílio com a informática e pela amizade.

Aos amigos Roberto e Maria José pela revisão do texto.

Ao Instituto Federal do Espírito Santo (IFES) pelo apoio durante todo o período de estudo.

A todos os amigos do IFES que direta ou indiretamente auxiliaram este trabalho.

Aos novos amigos, Doris, Edna Victor, Luis, Viviane, Girley, Dani, Flávia, Kellie, Luciana, Hugo, Eduardo, Kameoka, Bia, Victor, Pedro, Olivía e Isabela, pela convivência agradável, pelo carinho e amizade que sempre tiveram por mim. 
Ao Danilo, ao Rubens e ao Lívio pela valorosa ajuda nas soluções de problemas técnicos.

Ao meu marido João Carlos, pela dedicação, incentivo, carinho e amor.

Ao meu filho Bruno, por tornar minha vida iluminada.

Às minhas irmãs, Heloisa e Suely que, com muito carinho e apoio, não mediram esforços para que a conclusão deste trabalho se tornasse possível.

À memória do meu pai Amilcar e à minha mãe Arlinda pelo exemplo de vida.

À CAPES, pela concessão da bolsa de estudo. 


\section{RESUMO}

Neste trabalho, buscou-se verificar a possibilidade de, com a utilização do processo eletrolítico, se obter dióxido de manganês a partir da reciclagem de pilhas e baterias exauridas, visto a grande demanda por produtos que utilizam esse mineral. Utilizou-se, para tanto, uma solução eletrolítica que continha os íons metálicos: Ca (270mg/L), Ni (3000 mg/L), Co $(630 \mathrm{mg} / \mathrm{L}), \mathrm{Mn}(115300 \mathrm{mg} / \mathrm{L})$, $\mathrm{Ti}$ (400 mg/L) e Pb (20 mg/L) em meio de ácido sulfúrico, sintetizada, seguindo-se dados de pesquisa anterior. A produção do dióxido de manganês eletrolítico (DME) foi realizada galvanostaticamente, com a utilização de uma fonte estabilizada que monitorava o potencial do eletrodo de trabalho. Utilizaram-se, preliminarmente, um eletrodo de trabalho de chumbo e dois contra-eletrodos de grafite, à temperatura de $98 \stackrel{\circ}{\circ}\left( \pm 2^{\circ} \mathrm{C}\right)$ e densidade de corrente de $1,69 \mathrm{~A} \mathrm{dm}^{-2}$. Após a verificação preliminar da possibilidade de obtenção do DME, repetiu-se sistematicamente o processo, aplicando-se variações de densidade de corrente $\left(0,61 \mathrm{~A} \cdot \mathrm{dm}^{-2}\right.$ a $\left.1,93 \mathrm{~A}_{\mathrm{dm}} \mathrm{dm}^{-2}\right)$ e de $\mathrm{pH}(0,00$ a 1,20). O material obtido com essas variações foi analisado através dos processos de espectrometria de fluorescência de raios- $X$, difração de raios- $X$, área superficial específica pelo método BET e microscopia eletrônica de varredura (MEV). Os melhores resultados quanto a eficiência de corrente, pureza e área superficial se obtiveram com densidade de corrente entre $1,02 \mathrm{~A}^{-\mathrm{dm}^{-2}}$ e $1,39 \mathrm{~A}_{\mathrm{dm}} \mathrm{dm}^{-2}$ e com $\mathrm{pH}$ 0,50. Em todos os experimentos, como comprova a análise de difração de raios-X, foi constatada a obtenção da variedade alotrópica $\varepsilon-\mathrm{MnO}_{2}$, uma das formas viáveis para utilização na fabricação de pilhas. Os resultados apontam para a viabilidade desse processo de reciclagem como alternativa diante da escassez de fontes naturais de $\mathrm{MnO}_{2}$ com características compatíveis com a aplicação em questão e como forma de diminuição da poluição ambiental causada pelo descarte de pilhas e baterias.

Palavras - chave: Reciclagem de resíduos urbanos. Manganês. Eletrodeposição. 


\section{ABSTRACT}

Considering the growing demand for products containing manganese in its composition, this work seeks to verify the possibility of using depleted batteries as a source of manganese applying the electrolytic process. It was used an electrolyte solution containing the metal ions: Ca (270mg / L), Ni (3000 mg / L), Co (630 mg / L), $\mathrm{Mn}(115300 \mathrm{mg} / \mathrm{L}), \mathrm{Ti}(400 \mathrm{mg} / \mathrm{L})$ and $\mathrm{Pb}(20 \mathrm{mg} / \mathrm{L})$ in concentrated sulfuric acid, following data from previous research. The production of electrolytic manganese dioxide (EMD) was performed through galvanization using a stabilized source that monitored the potential of the working electrode. It was preliminary used an electrode of lead and two counter electrodes of graphite at a temperature of $98^{\circ} \mathrm{C}\left( \pm 2^{\circ} \mathrm{C}\right)$ and current density of $1.69 \mathrm{~A} \cdot \mathrm{dm}^{-2}$. After preliminary verifying the possibility of obtaining electrolytic manganese dioxide (EMD), the process was systematically repeated, applying different current density $\left(0.61 \mathrm{~A} . \mathrm{dm}^{-2}\right.$ to $\left.2.51 \mathrm{~A} . \mathrm{dm}^{-2}\right)$ and $\mathrm{pH}(0.00$ to 1.20$)$. The material obtained at these variations was analyzed through the process of X-ray fluorescence spectrometry, X-ray diffraction, specific surface area (BET) and scanning electron microscopy (SEM). The best values referring to current efficiency, level of purity and specific surface area were obtained with the current density

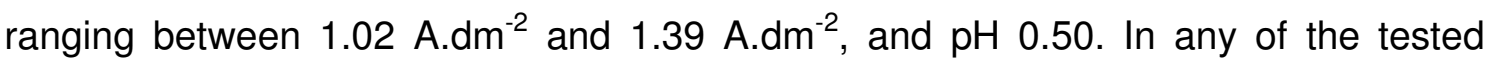
electrolysis conditions the $\varepsilon-\mathrm{MnO}_{2}$ structure was obtained as evidenced by the diffraction of $\mathrm{X}$-rays analysis. The results indicate the feasibility of this recycling process as an alternative before shortage of natural sources of $\mathrm{MnO}_{2}$ and as a means of reducing environmental pollution caused by the disposal of batteries.

Keywords: Recycling waste. Manganese. Electroplating 


\section{LISTA DE FIGURAS}

Figura 1 - Consumo setorial do manganês no Brasil em 2002, dados em porcentagem. 4

Figura 2 - Representação esquemática das variedades alotrópicas do $\mathrm{MnO}_{2}$. a) pirolusita $\left(\beta-\mathrm{MnO}_{2}\right)$, b) ramsdelita e c) $\mathrm{Y}-\mathrm{MnO}_{2}$

Figura 3 - Intercalação dos polimorfos (a) $\beta-\mathrm{MnO} 2$ e (b) $\mathrm{R}-\mathrm{MnO}_{2}$ na variedade (c) $\mathrm{Y}-\mathrm{MnO}_{2}$ onde $\mathrm{R}$ e $\mathrm{P}$ representam domínios de ramsdelita e pirolusita, respectivamente. 6

Figura 4 - Distribuição esquemática dos materiais que constituem uma célula primária de Leclanché................................................................................. 10

Figura 5 - Distribuição esquemática dos materiais que constituem uma célula .......12

Figura 6 - Diagrama esquemático de movimento de prótons e elétrons durante a descarga.

Figura 7 - Fluxograma do processo de obtenção do dióxido de manganês eletrolítico.

Figura 8- Foto da célula eletroquímica desenvolvida para produção do DME.

Figura 9- Detalhamento da tampa da célula eletrolítica. 34

Figura 10 - Foto do eletrodo de trabalho (anodo) e do contra-eletrodo (catodo).......35

Figura 11 - Foto da mudança de coloração da solução eletrolítica durante o aquecimento a)Solução eletrolítica antes do aquecimento b) solução eletrolítica após o aquecimento. 36

Figura 12 - Foto do DME produzido nas condições $\mathrm{j}=1,69 \mathrm{~A} \cdot \mathrm{dm}^{-2}$ e $\mathrm{T}=98^{\circ} \mathrm{C}$ após removido da superfície do eletrodo. 44

Figura 13- Difratograma de raios- $X$ da amostra do DME 46

Figura 14 - Efeito da densidade de corrente na eficiência de corrente anódica nos ensaios de produção do DME.

Figura 15- Efeito da densidade de corrente na área superficial do dióxido de manganês eletrolítico. 48 
Figura 16 - Efeito da densidade de corrente anódica na incorporação dos íons metálicos $\mathrm{Ca}, \mathrm{Ti}, \mathrm{Co}, \mathrm{Ni}$ e $\mathrm{Pb}$ nas amostras de DME.

Figura 17 - Difratogramas de raios-X das amostras de DME: a) 0,61 A.dm ${ }^{-2}$; b) $1,02 \mathrm{~A} \cdot \mathrm{dm}^{-2}$; c) $1,39 \mathrm{~A} \cdot \mathrm{dm}^{-2}$ obtidos a $98^{\circ} \mathrm{C}$ por $4 \mathrm{~h}$. 52

Figura 18 - Difratogramas de raios-X das amostras de DME: a) 1,93 A.dm ${ }^{-2}$ b) $2,51 \mathrm{~A} \cdot \mathrm{dm}^{-2}$ obtidos a $98^{\circ} \mathrm{C}$ por $4 \mathrm{~h}$. 53

Figura 19 - Imagem de elétrons retro-espalhados. Aspecto das partículas de DME após sua remoção do eletrodo (a) $0,61 \mathrm{~A} \cdot \mathrm{dm}^{-2}$ (b) $1,02 \mathrm{~A} \cdot \mathrm{dm}^{-2}$ (c) $1,39 \mathrm{~A} \cdot \mathrm{dm}^{-2}$ (d) 1,93 A.dm ${ }^{-2}$ (e) 2, $51 \mathrm{~A} \cdot \mathrm{dm}^{-2}$. 54

Figura 20 - Imagem de elétrons retro-espalhados. Morfologia do $\mathrm{MnO}_{2}$ obtido a $98^{\circ} \mathrm{C}$ por 4 h. (a) $0,61 \mathrm{~A} \cdot \mathrm{dm}^{-2}$ (b) $1,02 \mathrm{~A} \cdot \mathrm{dm}^{-2}$ .55

Figura 21 - Imagem de elétrons retro-espalhados. Morfologia do $\mathrm{MnO}_{2}$ obtido a $98^{\circ} \mathrm{C}$ por 4h. (a)1,39 A.dm ${ }^{-2}$ (b) 1,93 A.dm ${ }^{-2}$ (c) 2,51 A.dm 56

Figura 22 - Espectro de EDS da superfície do DME obtido na densidade de corrente $0,61 \mathrm{~A} \cdot \mathrm{dm}^{-2}$ por um período de $4 \mathrm{~h}$ a $98^{\circ} \mathrm{C}$. 57

Figura 23 - Espectro de EDS do material depositado no eletrodo de chumbo a diferentes densidades de corrente por período de 4 horas. (a) $1,02 \mathrm{~A}^{-\mathrm{dm}^{-2}}$ (b) $1,39 \mathrm{~A} \cdot \mathrm{dm}^{-2}$. 58

Figura 24 - Espectro de EDS do material depositado no eletrodo de chumbo a diferentes densidades de corrente por período de 4 horas. (a) 1,93 A.dm ${ }^{-2}$ (b) $2,51 \mathrm{~A} \cdot \mathrm{dm}^{-2}$. 59

Figura 25 -Imagem de elétrons retro-espalhados. Morfologia do DME produzido a $2,51 \mathrm{~A} \cdot \mathrm{dm}^{-2}$ 60

Figura 26- Espectro de EDS da região A da figura 25 61

Figura 27- Espectro de EDS da região B da figura 25. 61

Figura 28 - Efeito do pH na eficiência de corrente. 62

Figura 29 - Efeito do pH na área superficial do dióxido de manganês eletrolítico.....64

Figura 30- Efeito do pH na incorporação das impureza metálicas no DME. 66

Figura 31 - Difratograma de raios-X da amostra de DME obtido a $\mathrm{pH} 0,0$, por $7 \mathrm{~h}$ a $98^{\circ} \mathrm{C}$. 67

Figura 32 - Difratogramas de raios-X das amostras de DME obtidos a $98^{\circ} \mathrm{C}$, por $7 \mathrm{~h}$ : a) $\mathrm{pH} 0,25$; b) $0,50 \mathrm{c}) \mathrm{pH} 0,75$. 68 
Figura 33 - Difratogramas de raios- $X$ da amostra de DME obtido a $\mathrm{pH} 1,20$ por $7 \mathrm{~h}$ a $98^{\circ} \mathrm{C}$. 69

Figura 34 - Imagem de elétrons retro-espalhados. Morfologia do $\mathrm{MnO}_{2}$ eletrodepositado a diferentes concentrações de ácido sulfúrico, a $98^{\circ} \mathrm{C}$, por $7 \mathrm{~h}$. a) $0,5 \mathrm{~mol} / \mathrm{L}(\mathrm{pH} 0.00)$; b) $0,28 \mathrm{~mol} / \mathrm{L}(\mathrm{pH} 0,25)$; c) $0,16 \mathrm{~mol} / \mathrm{L}(\mathrm{pH} 0,50)$; d) $0,09 \mathrm{~mol} / \mathrm{L}(\mathrm{pH} 0,75) ; \mathrm{e}) 0,03 \mathrm{~mol} / \mathrm{L}(\mathrm{pH} 1,20)$ 70

Figura 35 - Espectro de EDS do material depositado no eletrodo de chumbo a diferentes concentrações de ácido sulfúrico, a $98^{\circ} \mathrm{C}$, por período de 7 horas. (a) $0,5 \mathrm{~mol} / \mathrm{L}(\mathrm{pH} 0.00)$ e b) $0,28 \mathrm{~mol} / \mathrm{L}(\mathrm{pH} 0,25)$. 71

Figura 36 - Espectro de EDS do material depositado no eletrodo de chumbo a diferentes concentrações de ácido sulfúrico, a $98^{\circ} \mathrm{C}$, por período de 7 horas a) $0,16 \mathrm{~mol} / \mathrm{L}(\mathrm{pH} 0,50)$; b) $0,09 \mathrm{~mol} / \mathrm{L}(\mathrm{pH} 0,75)$; c) $0,03 \mathrm{~mol} / \mathrm{L}(\mathrm{pH} 1,20)$ 


\section{LISTA DE TABELAS}

Tabela 1- Principais minerais de manganês...............................................................

Tabela 2- Características cristalográficas de diferentes formas de $\mathrm{MnO}_{2}{ }^{\circ} \ldots \ldots \ldots \ldots \ldots \ldots . . . .7$

Tabela 3 - Tipos de Baterias Primárias (não Recarregáveis ........................................8

Tabela 4 - Tipos de baterias secundárias (Recarregáveis) ……………………......

Tabela 5 - Percentagem dos principais componentes das pilhas em \% peso..............9

Tabela 6 - Componentes presentes na pilha zinco-carbono...................................10

Tabela 7 - Componentes presentes na pilha alcalina ..........................................12

Tabela 8 - Processos para reciclagem de pilhas e baterias. ..................................16

Tabela 9 - Especificações para minérios de manganês usados para fabricação de

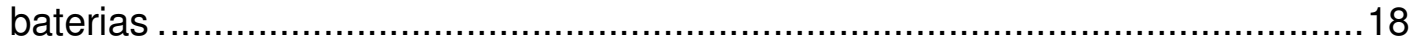

Tabela 10 - Especificações do dióxido de manganês eletrolítico. .............................19

Tabela 11 - Composição da solução eletrolítica.....................................................32

Tabela 12- Ensaios e parâmetros empregados nos ensaios de eletrólise realizados a diferentes densidades de corrente. ................................................................3

Tabela 13 - Ensaios e parâmetros empregados nos ensaios de eletrólise realizados

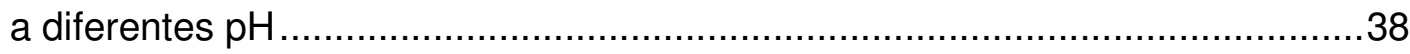

Tabela 14 - Potenciais Padrões de Redução a 25ํㅡ.............................................41

Tabela 15- Resultado da análise química por espectrometria de fluorescência de raios-X do DME obtido para $1,69 \mathrm{~A} \cdot \mathrm{dm}^{-2}$ e $98^{\circ} \mathrm{C}\left( \pm 2^{\circ} \mathrm{C}\right)$ e a composição do DME comercial (dados em porcentagem em massa). ..............................................44

Tabela 16 - Área superficial específica e tamanho médio das partículas das amostras de DME obtidas a diferentes densidades de correntes. .....................49

Tabela 17- Resultados das análises químicas por espectrometria de fluorescência de raios-X das amostras de DME obtidas em diferentes densidades de corrente (dados em porcentagem em massa).

Tabela 18 - Efeito da razão entre as concentrações do ácido sulfúrico e sulfato de manganês na eficiência de corrente. 
Tabela 19 - Tamanho médio das partículas das amostras de DME obtidas a diferentes concentrações de ácido sulfúrico. 65

Tabela 20- Resultados das análises químicas por espectrometria de fluorescência de raios- $X$ das amostras de DME obtidas em diferentes $\mathrm{pH}$ (dados em porcentagem em massa) ..........................................................................6 


\section{SUMÁRIO}

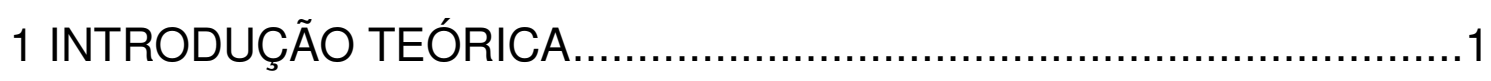

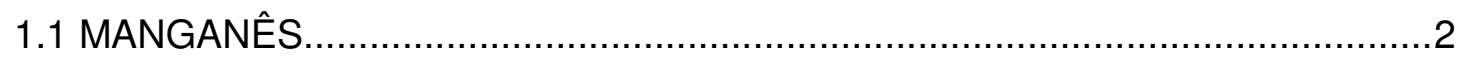

1.2 DIÓXIDO DE MANGANÊS ...........................................................................

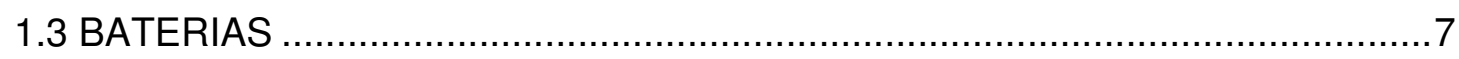

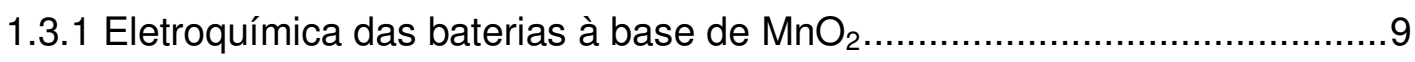

1.3.1.1 Pilhas Zinco-Carbono ..................................................................

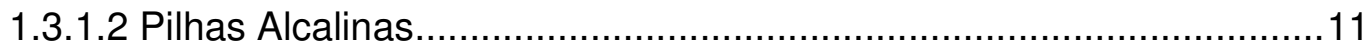

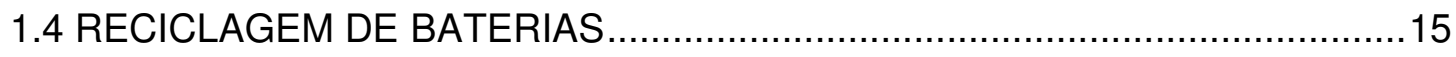

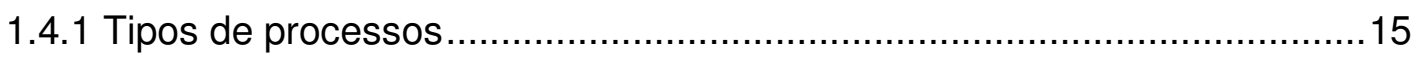

1.4.2 Recuperação do manganês ................................................................16

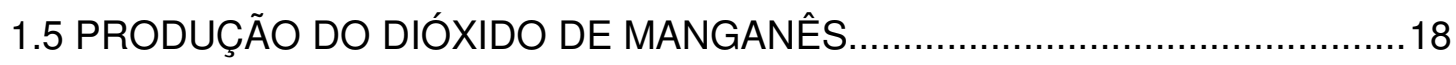

1.5.1 Produção do Dióxido de Manganês Químico (CMD) ………………........19

1.5.2 Produção do dióxido de manganês eletrolítico (DME) ………………........20

1.5.2.1 Condições de eletrólise para produção de DME.................................24

1.5.2.2 Influência de impurezas na produção de DME ...................................26

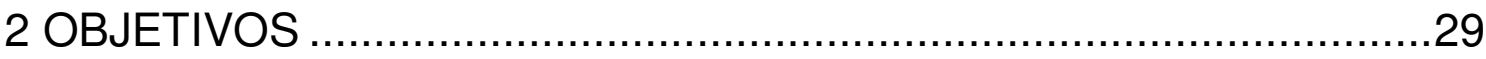

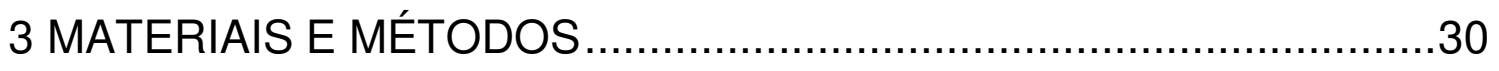

3.1 PREPARAÇÃO DA SOLUÇÃO ELETROLÍTICA .........................................32

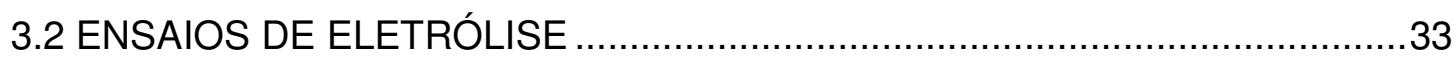

3.2.1. Ensaios Preliminares para Obtenção do Dióxido de Manganês Eletrolítico

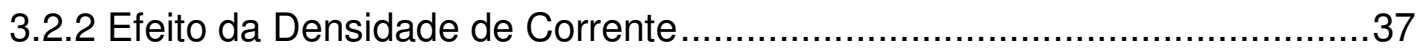

3.2.3 Efeito da concentração do Ácido Sulfúrico ……………………..............37

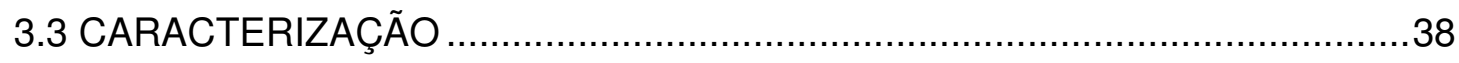


3.3.1 Espectrometria de Fluorescência de Raios-X..........................................39

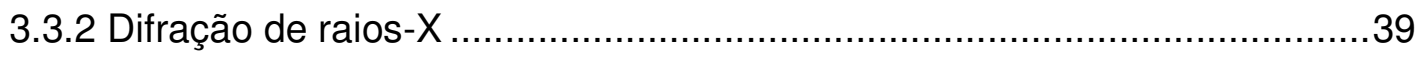

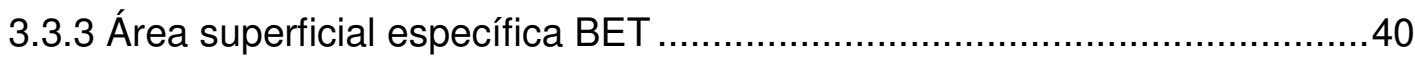

3.3.4 Microscopia Eletrônica de Varredura (MEV) ……………………….......40

4 RESULTADOS E DISCUSSÃO ....................................................41

4.1 ENSAIOS PRELIMINARES PARA OBTENÇÃO DO DIÓXIDO DE MANGANÊS

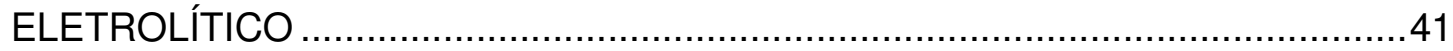

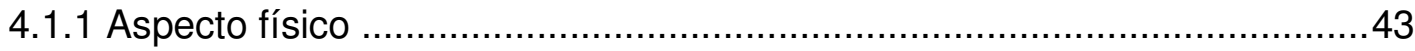

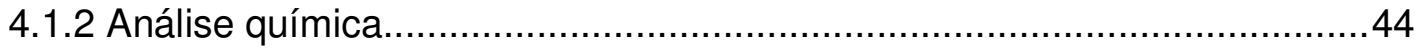

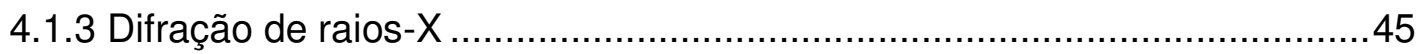

4.2 EFEITO DA DENSIDADE DE CORRENTE …………..............................46

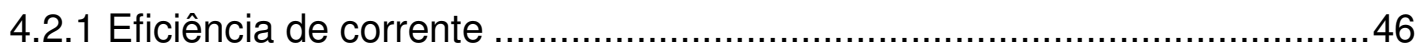

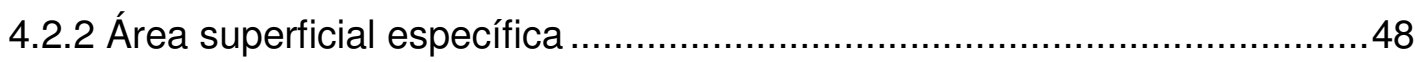

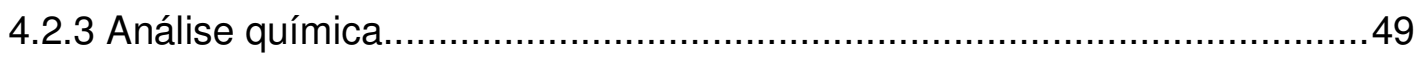

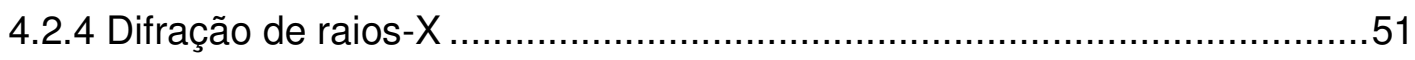

4.2.5 Microscopia eletrônica de varredura …………..........................................54

4.3 EFEITO DA CONCENTRAÇÃO DE ÁCIDO SULFÚRICO ...............................62

4.3.1 Eficiência de corrente .......................................................................62

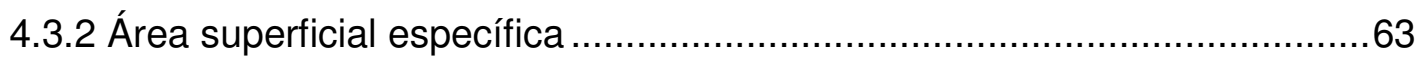

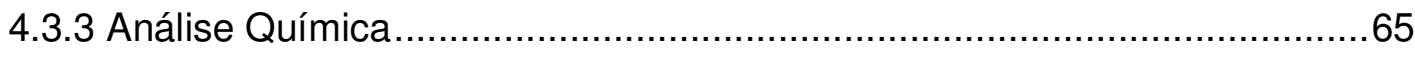

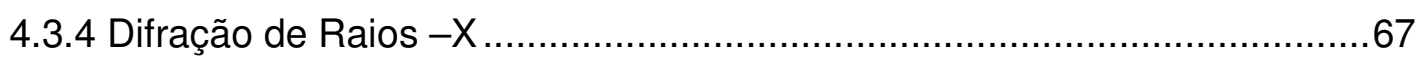

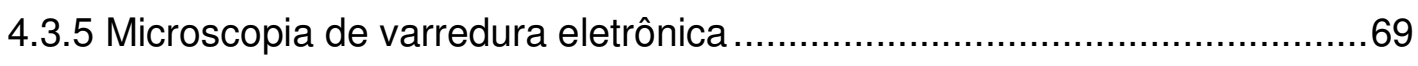

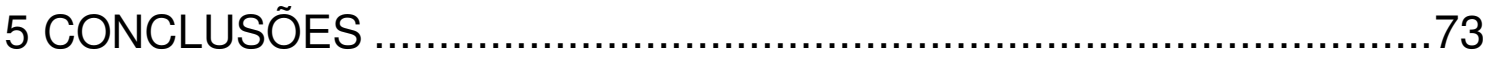

REFERÊNCIAS BIBLIOGRÁFICAS .............................................75 


\section{INTRODUÇÃO TEÓRICA}

O dióxido de manganês eletrolítico (DME) é o principal componente ativo presente nos catodos em vários sistemas de pilhas. O sistema mais comum dentre os que utilizam dióxido de manganês é o sistema de pilhas primárias alcalinas $\mathrm{Zn}$ / $\mathrm{MnO}_{2}$. Esse componente também é encontrado no sistema aquoso de pilhas $\mathrm{Zn}$ carbono e em algumas pilhas de lítio. Atualmente, tem sido investigado seu uso como precursor na produção do espinélio $\left(\mathrm{LiMn}_{2} \mathrm{O}_{4}\right)$, um dos principais candidatos a serem utilizados como material para catodo de baterias recarregáveis de lítio. ${ }^{(1,2)}$

A utilização do dióxido de manganês eletrolítico na indústria de pilhas alcalinas excedeu 23.000 t/ano em 2002. ${ }^{(3)} \mathrm{O}$ elevado consumo dessa substância decorre da crescente demanda por pilhas no mercado, gerada pela grande produção e consumo de dispositivos eletrônicos portáteis como câmeras digitais, MP3, celulares, computadores e brinquedos de alta tecnologia, cujas fontes de alimentação são, quase exclusivamente, pilhas que apresentam o sistema $\mathrm{Zn} / \mathrm{MnO}_{2}$. Essas pilhas representam uma percentagem significativa do total de baterias disponíveis no mercado, devido, principalmente, às características de desempenho do dióxido de manganês catódico. ${ }^{(4)}$ e a seu baixo custo.

Para ser utilizado na fabricação de pilhas, o dióxido de manganês tem que, necessariamente, apresentar propriedades especiais como alto grau de pureza, grande atividade eletroquímica e não deve conter impurezas tais como cobre, níquel, arsênio e cobalto, nem teor de óxido de ferro acima de 4\%. Assim, embora depósitos sedimentares sejam encontrados em todo o mundo, a dificuldade para se obter na natureza o dióxido de manganês propício para a produção de pilhas advém do fato de que em um número limitado desses depósitos existem minérios com teores de manganês em quantidade suficiente para seu aproveitamento econômico em escala industrial. ${ }^{(5)}$

Os minerais de manganês extraídos da natureza podem, portanto, seguir duas diferentes rotas na produção de pilhas. Caso os minerais atendam às exigências para esse uso, podem ser utilizados diretamente (in natura) e, caso não atendam a essas exigências, são utilizados como matéria prima na síntese do 
dióxido de manganês, por meio de procedimentos químicos ou métodos eletroquímicos. ${ }^{(5)}$

Com a crescente demanda por produtos que contém manganês em sua composição, torna-se cada vez mais necessário o uso de fontes secundárias desse metal. Para isso, vem-se estudando a utilização de minérios de baixo grau de manganês (inferior a 40\%), de nódulos oceânicos de manganês e de materiais que contém manganês tais como, sucatas de aço, eletrodos gastos, catalisadores usados, escórias e resíduos de pilhas. ${ }^{(3)}$

Dentre essas propostas de fontes secundárias, fixamo-nos, neste trabalho, na utilização de baterias exauridas, que é viável devido ao alto teor de dióxido de manganês (28 a 38\%) presente na composição das pilhas produzidas com esse material. ${ }^{(6)}$

Atualmente a rota hidrometalúrgica tem sido muito usada para a separação de metais presentes nas pilhas e baterias. ${ }^{(7,8,9)} \mathrm{O}$ licor proveniente do tratamento hidrometalúrgico durante 0 processo de reciclagem de pilhas pode ser, potencialmente, importante fonte de manganês. O manganês reduzido na etapa pirometalurgica é lixiviado quase que totalmente na etapa hidrometalúrgica, o que gera uma solução com elevada concentração de íons $\mathrm{Mn}^{2+}$.(10)

O objetivo deste trabalho reside na proposta de utilização do processo eletrolítico para a recuperação do manganês presente na lixívia de pilhas e baterias exauridas.

\subsection{MANGANÊS}

O manganês é o décimo-segundo elemento mais abundante, em peso, na crosta terrestre e é extraído predominantemente na forma do minério pirolusita, $\mathrm{MnO}_{2}$. Devido a sua afinidade com o oxigênio, o enxofre e o carbono, apresenta-se na natureza distribuído nos ambientes geológicos nas formas de óxidos, hidróxidos, sulfetos, silicatos e carbonatos. ${ }^{(3)}$

$\mathrm{Na}$ Tabela 1 estão relacionados os principais minerais de manganês com suas composições químicas e teores de manganês. ${ }^{(11)}$ 
Tabela 1- Principais minerais de manganês. ${ }^{(11)}$

\begin{tabular}{lcc}
\hline Mineral & Composição química principal & Teor de manganês(\%) \\
\hline Bixbyita & $\mathrm{Mn}_{2} \mathrm{O}_{3}$ & $30,0-40,0$ \\
\hline Braunita & $2 \mathrm{Mn}_{2} \mathrm{O}_{3} \cdot \mathrm{MnSiO}_{3}$ & 66 \\
\hline Criptomelana & $\mathrm{KMn}_{8} \mathrm{O}_{16}$ & 59,8 \\
\hline Hausmanita & $\mathrm{Mn}_{3} \mathrm{O}_{4}$ & 72 \\
\hline Jacobsita & $\mathrm{MnFe}_{2} \mathrm{O}_{4}$ & 24 \\
\hline Manganita & $\mathrm{Mn}_{2} \mathrm{O}_{3} \cdot \mathrm{H}_{2} \mathrm{O}$ & 62 \\
\hline Psilomelana & $\mathrm{mMnO}_{\mathrm{MnO}} \cdot \mathrm{n} \mathrm{H}_{2} \mathrm{O}$ & $45-60$ \\
\hline Pirolusita & $\mathrm{MnO}_{2}-\beta$ & $62-63$ \\
\hline Rodocrosita & $\mathrm{MnCO}_{3}$ & 47,8 \\
\hline Rodonita & $(\mathrm{Mn}, \mathrm{Ca}, \mathrm{Fe}, \mathrm{Zn}) \mathrm{SiO}_{3}$ & 47,8 \\
\hline
\end{tabular}

Os minérios, segundo seu teor de manganês, podem ser divididos em: minério de manganês $(\mathrm{Mn}>35 \%)$, minério ferruginoso $(10 \%<\mathrm{Mn}<35 \%)$ e minério de ferro manganesífero $(5 \%<\mathrm{Mn}<10 \%){ }^{(11)}$

No Brasil, as reservas estão assim distribuídas: $44,72 \%$ no Estado do Mato Grosso do Sul, 33,09\% no Estado do Pará, 15,18\% em Minas Gerais e o restante $(7,01 \%)$ está distribuído, em ordem decrescente, pelos Estados do Amapá, Bahia, Espírito Santo, São Paulo e Goiás. ${ }^{(11)}$

O metal puro tem poucas aplicações e $82 \%$ dos minérios de manganês produzidos são utilizados na indústria siderúrgica para a produção de ligas. A mais importante delas é a ferro manganês, que contém $80 \%$ de manganês. ${ }^{(12)}$ As aplicações de manganês na indústria siderúrgica se devem a suas características físico-químicas, pois ele atua como agente dessulfurante (provoca diminuição da quantidade de enxofre) e desoxidante (reage com o oxigênio com maior intensidade que 0 ferro). Nos processos modernos de aciaria é crescente o emprego de ferroligas à base de manganês. O consumo setorial de manganês no Brasil em 2002 pode ser observado na Figura 1. ${ }^{(11)}$ 


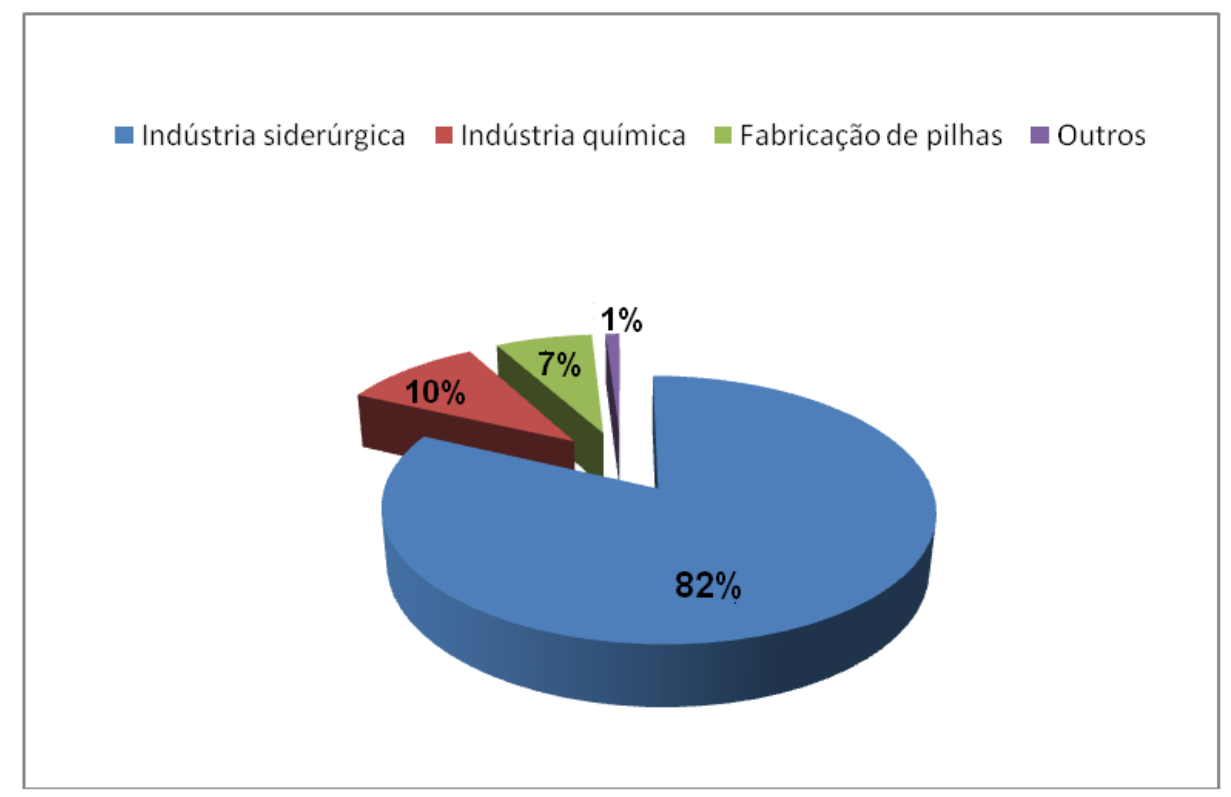

Figura 1 - Consumo setorial do manganês no Brasil em 2002, dados em porcentagem. ${ }^{(11)}$

Na indústria não metalúrgica, o manganês é usado na produção de reagentes químicos, fertilizantes, tintas, vernizes e sob a forma de óxidos, na fabricação de baterias primárias e secundárias. ${ }^{(5)}$

\subsection{DIÓXIDO DE MANGANÊS}

O dióxido de manganês, $\mathrm{MnO}_{2}$, ocorre na natureza como o mineral pirolusita, contendo cerca de 62-63\% de manganês. Esse mineral apresenta brilho metálico, densidade relativa entre 4,7-4,9, dureza 2,5 e é encontrado na cor preta. ${ }^{(7)}$

É um dos óxidos de manganês mais utilizados como catalisador ativo em várias reações de oxidação ou redução e pode ser usado como catalisador para a oxidação do metano e do monóxido de carbono. ${ }^{(13)}$ Também é empregado para dar coloração ametista ao vidro, para a descoloração de vidros que apresentam coloração verde devido à presença de ferro, para a produção de cloro e oxigênio e como agente oxidante na química orgânica. ${ }^{(12)}$

O uso mais importante do dióxido de manganês, porém, se dá na fabricação de pilhas primárias do tipo Leclanché (zinco-carbono) e do tipo alcalina. ${ }^{(14)} \mathrm{A}$ cada 
ano cresce o interesse no uso desse material como precursor na obtenção do espinélio, $\mathrm{LiMn}_{2} \mathrm{O}_{4}$, usado como catodo de baterias recarregáveis de lítio. ${ }^{(15)}$

O dióxido de manganês destinado à fabricação de pilhas deve apresentar alto grau de pureza e grande atividade eletroquímica. Segundo Pagnanelli et $\mathrm{al}^{(16)}$, os dióxidos de manganês mais importantes do ponto de vista comercial são aqueles que são ativos eletroquimicamente e, portanto, utilizados em células de pilhas secas. A atividade eletroquímica do $\mathrm{MnO}_{2}$ é influenciada por sua estrutura cristalina, pelo tamanho da partícula, e pela área superficial. ${ }^{(17)}$

O dióxido de manganês pode se apresentar em várias formas alotrópicas, com diferentes atividades eletroquímicas. As formas alotrópicas do dióxido de manganês são $\alpha, \beta, \varepsilon, \gamma$, ramsdelita, dentre outras, e, de acordo com Prélot et al. ${ }^{(18)}$, as que apresentam maior atividade eletroquímica são $\gamma$ e $\varepsilon$, o que é decorrente do alto grau de desordem que apresentam.

A pirolusita, também conhecida como $\beta-\mathrm{MnO}_{2}$, nas condições ambientes, apresenta a estrutura tetragonal do rutilo. A ramsdelita tem simetria ortorrômbica e maior atividade eletroquímica que a pirolusita. A forma alotrópica $\varepsilon-\mathrm{MnO}_{2}$ é polimórfica, com simetria hexagonal, e tem atividade eletroquímica similar à da variedade $\gamma-\mathrm{MnO}_{2}{ }^{(19)}$

Os esquemas que representam as variedades alotrópicas $\beta, y$ e ramsdelita podem ser observadas na Figura 2 . $^{(20)}$

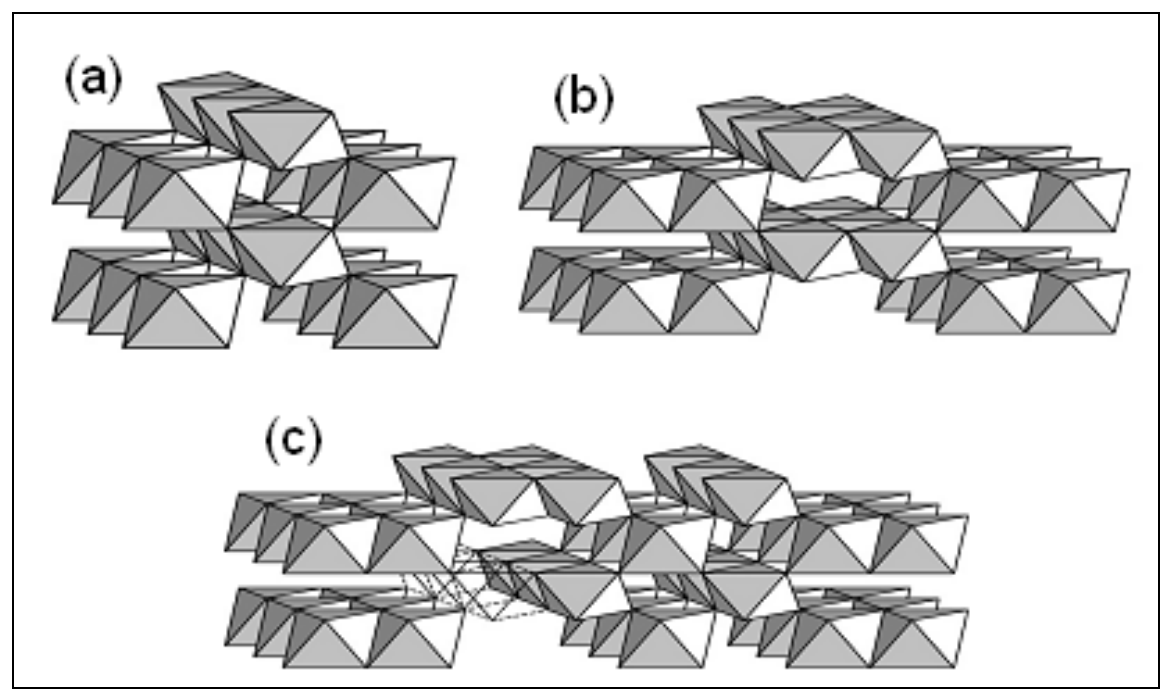

Figura 2 - Representação esquemática das variedades alotrópicas do $\mathrm{MnO}_{2}$.a) pirolusita $\left(\beta-\mathrm{MnO}_{2}\right)$, b) ramsdelita e c) $\mathrm{Y}-\mathrm{MnO}_{2}{ }^{(20)}$ 
A Nsutita, $\gamma-\mathrm{MnO}_{2}$, apresenta uma estrutura que é uma mistura de fase rutilo$\mathrm{MnO}_{2}$ e ramsdelita ${ }^{(21)}$, apresentando canais unidimensionais que facilitam a inserção de prótons ou lítio. Por isso, esta é a fase utilizada na produção de eletrodos de pilhas alcalinas comerciais. A Figura 3 apresenta essa estrutura(22).

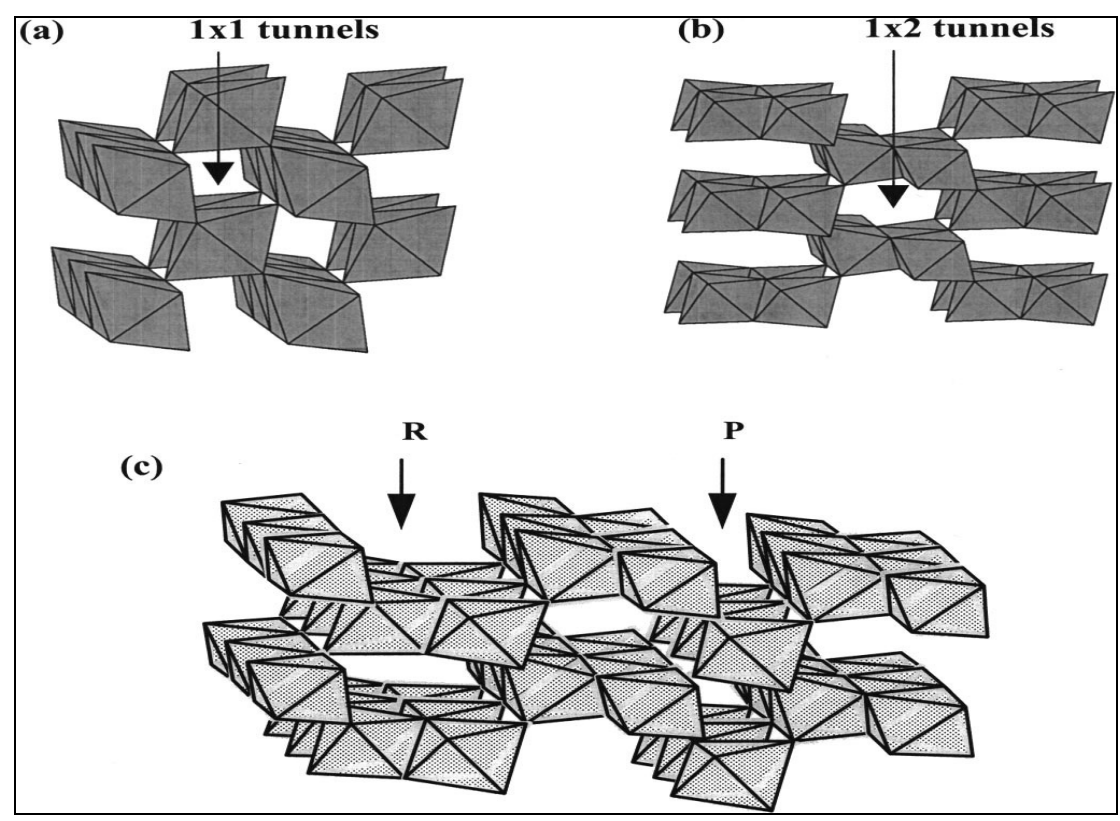

Figura 3 - Intercalação dos polimorfos (a) $\beta-\mathrm{MnO} 2$ e (b) $\mathrm{R}-\mathrm{MnO}_{2}$ na variedade (c) $\mathrm{Y}-\mathrm{MnO}_{2}$ onde $\mathrm{R}$ e $\mathrm{P}$ representam domínios de ramsdelita e pirolusita, respectivamente. ${ }^{\text {(22) }}$

A variedade $\varepsilon-\mathrm{MnO}_{2}$ tem basicamente a mesma estrutura da $\gamma-\mathrm{MnO}_{2}$ (quando domínios de rutilo existem numa rede de ramsdelita), contudo apresenta maior grau de desordem, alta porosidade e elevada área ativa. ${ }^{(23)}$

A fase $\alpha-\mathrm{MnO}_{2}$ (simetria tetragonal, grupo espacial 14/m) é uma variante que apresenta estrutura onde duplas cadeias do octaedro $\mathrm{MnO}_{6}$ estão interligadas, formando canais unidimensionais que se estendem paralelamente ao eixo cristalográfico na cela unitária. Essa fase pode ser encontrada na forma mineral da família criptomelana(24) como $\mathrm{BaMn}_{8} \mathrm{O}_{16}$ e $\mathrm{KMn}_{8} \mathrm{O}_{16}$, por reação de $\mathrm{Mn}_{2} \mathrm{O}_{3}$ ou $\mathrm{Li}_{2} \mathrm{MnO}_{3}$, em soluções concentradas de ácido sulfúrico. Tanto na forma mineral como na sintética do $\alpha-\mathrm{MnO}_{2}$, verifica-se a presença de canais de intercalação no interior da estrutura, que podem estar eventualmente preenchidos com íons $\mathrm{Ba}, \mathrm{K}$ ou moléculas de $\mathrm{H}_{2} \mathrm{O}^{(25)}$. Esses íons prejudicam a inserção de cátions de pequena dimensão, como prótons ou lítio, e a estrutura mostra-se relativamente pouco 
estável frente à reação de intercalação das espécies iônicas. Isso explica porque a fase $\alpha$ do $\mathrm{MnO}_{2}$ não é utilizada em pilhas alcalinas ou baterias de Li comerciais.

As características cristalográficas de diferentes variedades alotrópicas do dióxido de manganês são mostradas na Tabela ${ }^{2}{ }^{(23)}$

Tabela 2- Características cristalográficas de diferentes formas de $\mathrm{MnO}_{2}{ }^{(23)}$.

\begin{tabular}{ccc}
\hline Tipo $\mathrm{MnO}_{2}$ & Estrutura & Simetria \\
\hline$\gamma-\mathrm{MnO}_{2}$ & Holandita & Tetragonal \\
\hline$\beta-\mathrm{MnO}_{2}$ & Rutilo & Tetragonal \\
\hline$\varepsilon-\mathrm{MnO}_{2}$ & $\begin{array}{c}\text { Ramsdelita/Rutilo } \\
\text { intercalado }\end{array}$ & Hexagonal \\
\hline $\mathrm{R}-\mathrm{MnO}_{2}$ & Ramsdelita & Otorrômbica \\
\hline
\end{tabular}

\subsection{BATERIAS}

Baterias são sistemas eletroquímicos que fornecem trabalho elétrico útil a partir de reações químicas entre os reagentes contidos em seu interior. O princípio de funcionamento de uma bateria baseia-se na reação eletroquímica em que a oxidação ocorre no anodo e a redução ocorre no catodo por meio de um eletrólito (condutor iônico). ${ }^{(26)}$

Podem ser classificadas em primárias ou não recarregáveis e secundárias ou recarregáveis. Nas baterias primárias, popularmente chamadas de pilhas, as reações acabam destruindo um dos eletrodos, normalmente o negativo e o sistema não pode ser recarregado. Fazem parte dessa classe as pilhas zinco-carbono (Leclanché), as pilhas zinco - cloreto, as pilhas alcalinas e as pilhas de litio. A Tabela 3 resume os principais tipos de baterias primárias. ${ }^{(6,27,28)}$ 
Tabela 3 - Tipos de Baterias Primárias (não Recarregáveis). ${ }^{(6,27,28)}$

\begin{tabular}{|c|c|c|c|}
\hline Tipo & $\begin{array}{l}\text { Eletrodo } \\
\text { positivo } \\
\text { (Catodo) }\end{array}$ & $\begin{array}{l}\text { Eletrodo negativo } \\
\text { (Anodo) }\end{array}$ & Eletrólito \\
\hline $\begin{array}{l}\text { Zn-Carbono } \\
\text { (Leclanché) }\end{array}$ & $\mathrm{MnO}_{2}$ & $\mathrm{Zn}$ & $\begin{array}{l}\mathrm{NH}_{4} \mathrm{Cl} / \mathrm{ZnCl}_{2} / \mathrm{MnO}_{2} / \\
\mathrm{C} \text { (pó)/amido úmidos }\end{array}$ \\
\hline Zinco- cloreto & $\mathrm{MnO}_{2}$ & $\mathrm{Zn}$ & $\mathrm{ZnCl} / \mathrm{MnO}_{2} / \mathrm{C}$ (pó)/amido úmidos \\
\hline Alcalina & $\mathrm{MnO}_{2}$ & $\begin{array}{l}\text { Zn em pó/Solução } \\
\mathrm{KOH}\end{array}$ & $\begin{array}{l}\mathrm{NH}_{4} \mathrm{Cl} / \mathrm{ZnCl} / \mathrm{MnO}_{2} / \mathrm{KOH} / \mathrm{C} \text { (pó)/amido } \\
\text { úmidos }\end{array}$ \\
\hline Mercúrio -zinco & $\mathrm{HgO}$ & Zn em pó & Potássio e/ou $\mathrm{NaOH}$ \\
\hline Lítio & $\mathrm{MnO}_{2}$ & $\mathrm{Li}$ & $\begin{array}{l}\text { Solventes orgânicos e/ou soluções } \\
\text { salinas }\end{array}$ \\
\hline Zinco-ar & $\mathrm{O}_{2}$ & $\mathrm{Zn}$ & $\mathrm{KOH}$ \\
\hline Zinco-prata & $\mathrm{Ag}$ & $\mathrm{Zn}$ & Potássio e/ou $\mathrm{NaOH}$ \\
\hline
\end{tabular}

As baterias secundárias são células em que a reação eletroquímica pode ser revertida com auxílio de uma fonte externa de corrente elétrica, que recarrega 0 sistema. Assim, nessas baterias podem ocorrer sucessivamente os processos de descarga e recarga.

A Tabela 4 resume os principais tipos de baterias secundárias, com seus respectivos catodo, anodo e eletrólito. ${ }^{(6,27,28)}$

Tabela 4 - Tipos de baterias secundárias (Recarregáveis). ${ }^{(6,27,28)}$

\begin{tabular}{|c|c|c|c|}
\hline Tipo & $\begin{array}{c}\text { Eletrodo } \\
\text { positivo(Catodo) }\end{array}$ & $\begin{array}{c}\text { Eletrodo } \\
\text { negativo(Anodo) }\end{array}$ & Eletrólito \\
\hline Níquel-Cádmio & $\mathrm{NiO}(\mathrm{OH})$ & $\mathrm{Cd}$ & $\overline{\mathrm{KOH} \text { e } \mathrm{LI}(\mathrm{OH})_{2}}$ \\
\hline Íon-Lítio & $\begin{array}{c}\mathrm{Li}_{x} \mathrm{MA}_{2} \\
\left(\mathrm{LiCoO}_{2}, \mathrm{LiNiO}_{2} \mathrm{e}\right. \\
\left.\mathrm{LiMn}_{2} \mathrm{O}_{4}\right)\end{array}$ & $\mathrm{SO}_{2}, \mathrm{FeS}_{2}$ & $\mathrm{LiPF}_{6}$ \\
\hline $\begin{array}{c}\text { Níquel-meta hidreto } \\
(\mathrm{NiMH})\end{array}$ & $\mathrm{Ni}(\mathrm{OH})_{2}$ & $\begin{array}{c}\text { Liga armazenadora } \\
\text { de hidrogênio } \\
\text { (Ni,Co,Mn,La,Ce,Pr, } \\
\text { Nd,Al,Zn) }\end{array}$ & $\begin{array}{c}\text { Solução } \\
\text { constituída } \\
\text { principalmente } \\
\text { de KOH }\end{array}$ \\
\hline Chumbo-ácido & $\mathrm{PbO}_{2}$ & $\mathrm{~Pb}$ & $\mathrm{H}_{2} \mathrm{SO}_{4}$ \\
\hline
\end{tabular}

Cada tipo de bateria possui sua própria combinação de materiais. A Tabela 5 apresenta a porcentagem dos principais componentes das pilhas em \% peso. ${ }^{(29,30)}$ 
Tabela 5 - Percentagem dos principais componentes das pilhas em \% peso. ${ }^{(29,30)}$

\begin{tabular}{cccccccc}
\hline Componentes & Alcalina & $\mathrm{Zn}-\mathrm{C}$ & $\mathrm{Hg}-\mathrm{Zn}$ & $\mathrm{Zn}-\mathrm{Ag}$ & $\mathrm{Zn}-\mathrm{ar}$ & Lítio & Ni-Cd \\
\hline $\mathrm{Zn}$ & 14 & 17 & 11 & 10 & 30 & - & - \\
\hline $\mathrm{Mn}$ & 22 & 29 & - & - & - & - & - \\
\hline $\mathrm{Hg}$ & - & $0-0,2$ & 33 & 1 & 1 & - & - \\
\hline $\mathrm{Ni}$ & $0-0,02$ & $0-0,08$ & - & - & - & - & 29 \\
\hline $\mathrm{Cd}$ & - & 0 & - & - & - & - & 14 \\
\hline $\mathrm{Fe}$ & 37 & 16 & 22 & 22 & 60 & 60 & 31 \\
\hline $\mathrm{Ag}$ & - & - & - & 27 & 1 & - & - \\
\hline $\mathrm{Li}$ & - & - & - & - & - & $10-30$ & - \\
\hline Eletrólito & 0,01 & $0,5-1$ & $\sim 33$ & 1 & 1 & - & - \\
\hline Carbono & 3 & 7 & - & - & - & - & - \\
\hline Papel/Plástico & 5 & 10 & 7 & 7 & 7 & 7 & - \\
\hline
\end{tabular}

\subsubsection{Eletroquímica das baterias à base de $\mathrm{MnO}_{2}$}

O dióxido de manganês está presente principalmente nas pilhas do tipo Zincocarbono e nas pilhas alcalinas. ${ }^{(6)}$.

\subsubsection{Pilhas Zinco-Carbono}

A pilha zinco-carbono é constituída por um eletrólito, que é uma mistura de cloreto de amônio e cloreto de zinco em solução aquosa, um revestimento externo de zinco, que tem as funções de eletrodo positivo (anodo) e de recipiente para o conjunto, e um catodo (eletrodo negativo), composto de pó de dióxido de manganês misturado com carbono prensado sobre um bastão também de carbono. $\mathrm{O}$ carbono é adicionado ao catodo para aumentar a condutividade elétrica e reter a umidade. $\mathrm{O}$ eletrólito fica contido entre a haste de carbono e o revestimento de zinco. ${ }^{(26)}$

O dióxido de manganês age como despolarizador, evitando a formação de hidrogênio e de amônia e o consequente aumento da pressão interna. Isso é necessário pois, se os gases hidrogênio e amônia ficam armazenados ao redor do catodo, podem impedir que os íons fluam no interior da pilha, chegando a ocasionar queda da corrente, pois os gases são maus condutores de eletricidade e sua 
formação acaba aumentando a resistência elétrica interna. ${ }^{(31)} \mathrm{A}$ concentração de dióxido de manganês nesse tipo de pilha está na faixa de 28 a $32 \%{ }^{(6)}$ A Tabela 6 indica a composição média de uma pilha zinco-carbono ${ }^{(6)}$ e a Figura 4 mostra o esquema da pilha zinco carbono. ${ }^{(32)}$

Tabela 6 - Componentes presentes na pilha zinco-carbono. ${ }^{(6)}$

\begin{tabular}{l|c}
\hline \multicolumn{1}{c|}{ Componentes } & Quantidades (\%) \\
\hline Dióxido de manganês & $28-32$ \\
\hline Aço & $8-14$ \\
\hline Zinco & $16-20$ \\
\hline Grafite & $7-13$ \\
\hline Cloreto de zinco & $6-10$ \\
\hline Água, papel e plástico & Balanceamento (11-35) \\
\hline
\end{tabular}

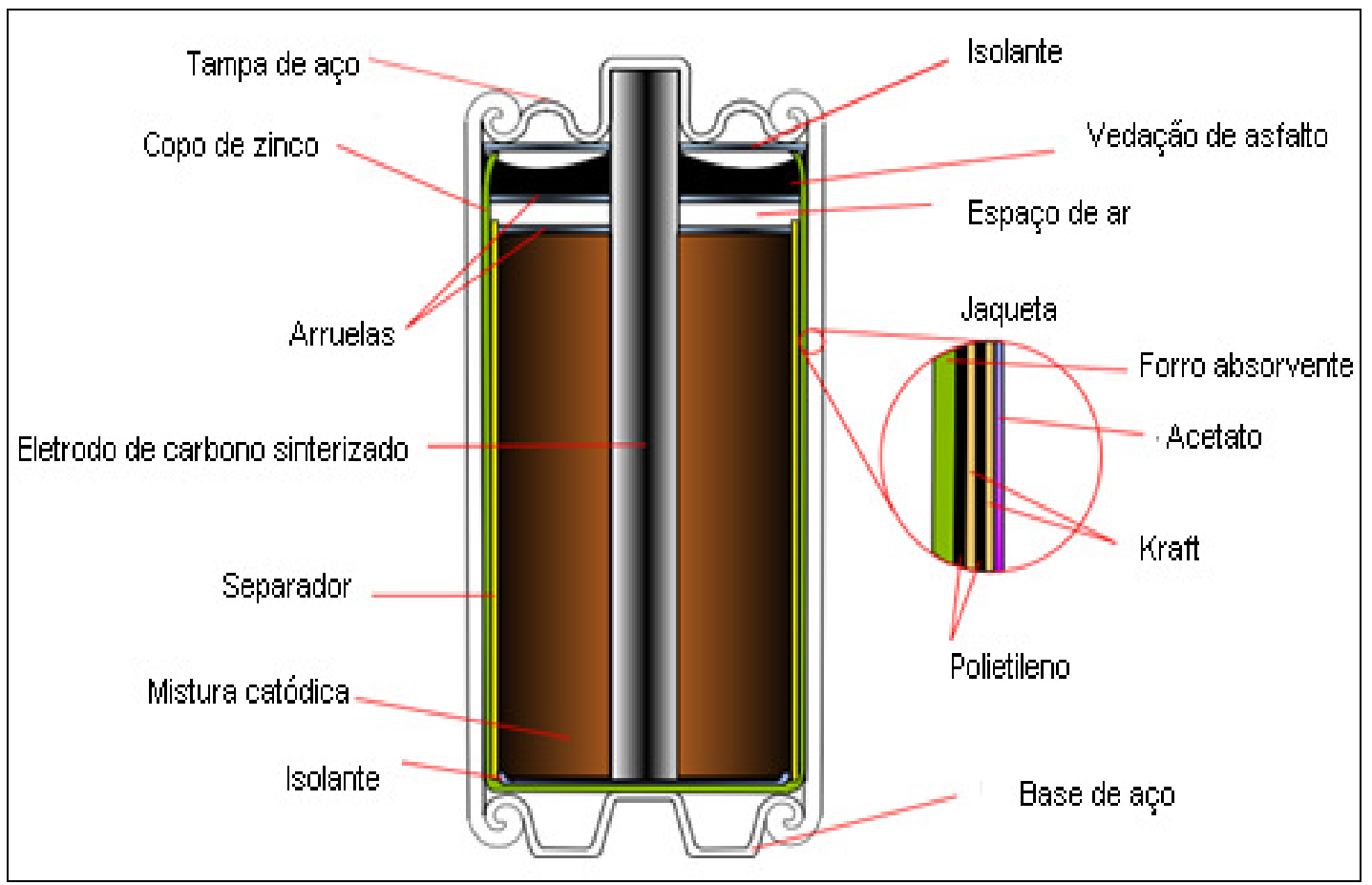

Figura 4 - Distribuição esquemática dos materiais que constituem uma célula primária de Leclanché. 32 )

Nesta célula, a reação de oxidação ocorre no anodo $(\mathrm{Zn})$ e a reação de redução ocorre no catodo $\left(\mathrm{MnO}_{2}\right) \cdot{ }^{(31)}$

Anodo: Oxidação do zinco

$\mathrm{Zn} \rightarrow \mathrm{Zn}^{2+}+2 \mathrm{e}^{-}$ 
Catodo: Redução parcial do dióxido de manganês

$2 \mathrm{NH}_{4}^{+}+2 \mathrm{MnO}_{2}+2 \mathrm{e}^{-} \rightarrow \mathrm{Mn}_{2} \mathrm{O}_{3}+\mathrm{H}_{2} \mathrm{O}+2 \mathrm{NH}_{3}$

A equação geral da célula é: $\mathrm{Zn}+2 \mathrm{MnO}_{2} \rightarrow \mathrm{ZnO}+\mathrm{Mn}_{2} \mathrm{O}_{3}$

Mecanismo:

O íon amônio, durante a reação, dá origem a dois produtos gasosos conforme a equação: $2 \mathrm{NH}_{4}^{+}+2 \mathrm{e}^{-} \rightarrow 2 \mathrm{NH}_{3}+\mathrm{H}_{2}$. Esses gases devem ser absorvidos de modo a evitar seu acúmulo e o aumento da pressão no interior do compartimento. Essa absorção ocorre por dois mecanismos. ${ }^{(32)}$

$\mathrm{ZnCl}_{2}+2 \mathrm{NH}_{3} \rightarrow \mathrm{Zn}\left(\mathrm{NH}_{3}\right)_{2} \mathrm{Cl}_{2}$

$2 \mathrm{MnO}_{2}+\mathrm{H}_{2} \rightarrow \mathrm{Mn}_{2} \mathrm{O}_{3}+\mathrm{H}_{2} \mathrm{O}$

\subsubsection{Pilhas Alcalinas}

As pilhas alcalinas são uma variação das pilhas zinco-carbono, em que o eletrólito é constituído de hidróxido de potássio em substituição ao cloreto de amônio. Novamente, o zinco serve como anodo e o dióxido de manganês funciona como catodo. Entretanto, o eletrólito contém hidróxido de potássio que é muito condutivo o que resulta em baixa impedância interna da célula. $O$ anodo de zinco está na forma de pó, que oferece uma grande área efetiva. Isso permite à pilha liberar mais corrente do que a pilha de zinco comum Ela pode ser armazenada por um período mais longo sem perdas significativas, e também pode fornecer correntes mais altas por períodos de tempo maiores que a zinco-carbono. Isto ocorre porque na pilha alcalina não há produção de gases em torno dos eletrodos. ${ }^{(26)}$

O catodo é uma mistura de dióxido de manganês eletrolítico e pó de grafite. Esta mistura é compactada e inserida em uma lata de aço. Este conjunto (mistura e lata de aço) se torna o catodo da pilha alcalina. $O$ anodo é inserido dentro da lata, sendo separado do catodo por uma barreira, que é um separador de papel 
embebido em um eletrólito que promove condutividade iônica ou eletrolítica. ${ }^{(27)}$ A Tabela 7 apresenta os principais componentes das pilhas alcalinas. ${ }^{(6)}$

\begin{tabular}{cc} 
Tabela $7-$ Componentes presentes na pilha alcalina. $^{(6)}$ \\
\hline Componentes & $\begin{array}{c}\text { Quantidades } \\
(\%)\end{array}$ \\
\hline Dióxido de manganês & $32-38$ \\
\hline Aço & $19-23$ \\
\hline Zinco & $11-16$ \\
\hline Hidróxido de potássio & $5-9$ \\
\hline Grafite & $3-5$ \\
\hline Sulfato de bário & $<5$ \\
\hline Água, papel, plástico, \\
outros
\end{tabular}

As pilhas alcalinas, além de mais duráveis, produzem mais energia que as de Leclanché, pois, ao contrário do que acontece nestas, mesmo no caso de corrente elétrica mais alta, não há queda acentuada da diferença de potencial. As pilhas alcalinas possuem um tempo de vida útil até dez vezes maior que as pilhas $\mathrm{Zn} / \mathrm{MnO}_{2}$. A Figura 5 apresenta um esquema de uma pilha alcalina. ${ }^{\left({ }^{32}\right)}$

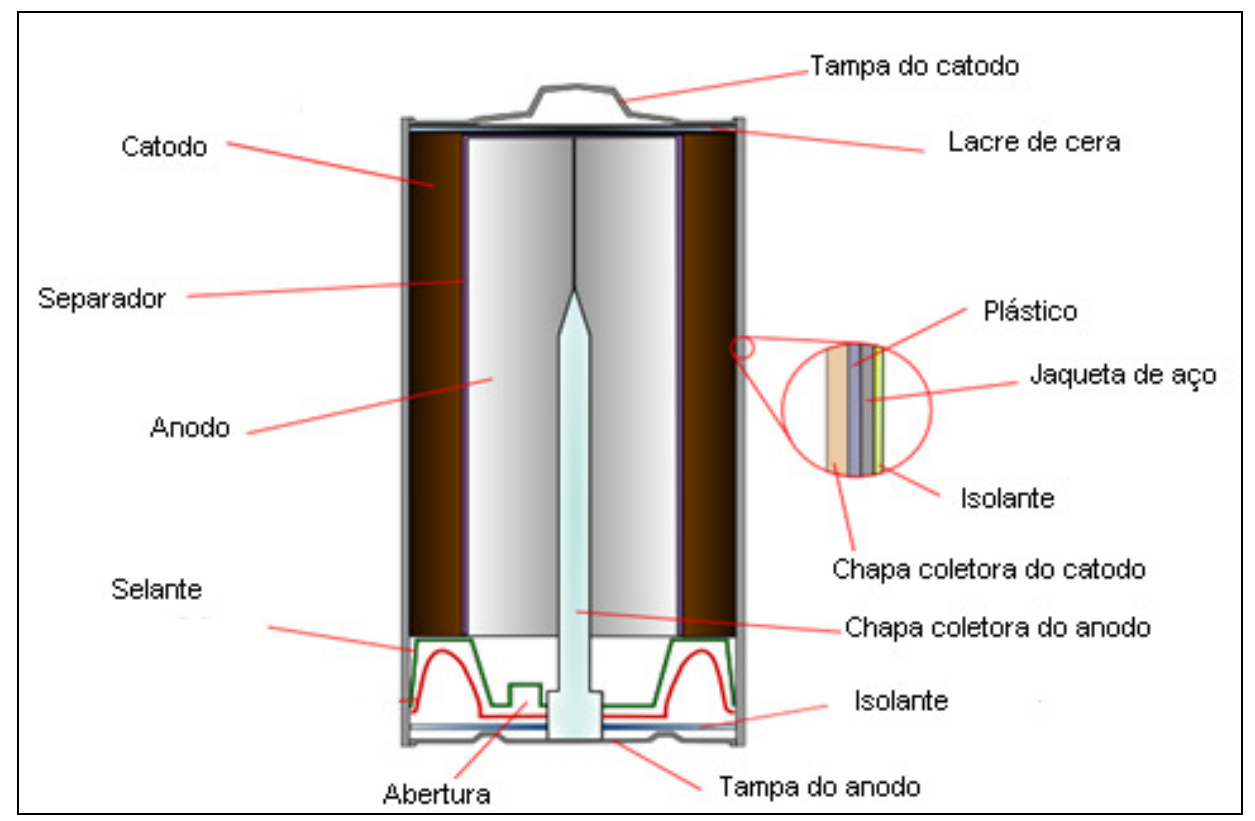

Figura 5 - Distribuição esquemática dos materiais que constituem uma célula alcalina /dióxido de manganês. (32) 
As seguintes semi-reações ocorrem dentro da célula. ${ }^{(32)}$

No Anodo:

$\mathrm{Zn}+2 \mathrm{OH}^{-} \rightarrow \mathrm{Zn}(\mathrm{OH})_{2}+2 \mathrm{e}^{-}$

$\mathrm{Zn}(\mathrm{OH})_{2}+2 \mathrm{OH}^{-} \rightarrow\left[\mathrm{Zn}(\mathrm{OH})_{4}\right]^{2-}$

No Catodo:

Para descarga parcial:

$2 \mathrm{MnO}_{2(\mathrm{~s})}+\mathrm{H}_{2} \mathrm{O}_{(\ell)}+2 \mathrm{e}^{-} \rightarrow \mathrm{Mn}_{2} \mathrm{O}_{3(\mathrm{~s})}+2 \mathrm{OH}_{(\mathrm{aq})}^{-}$

Para descarga total:

$\mathrm{MnO}_{2(\mathrm{~s})}+2 \mathrm{H}_{2} \mathrm{O}_{(\ell)}+2 \mathrm{e}^{-} \rightarrow \mathrm{Mn}(\mathrm{OH})_{2(\mathrm{~s})}+2 \mathrm{OH}^{-}$

A equação geral da célula é:

Para descarga parcial:

$\mathrm{Zn}+2 \mathrm{MnO}_{2} \rightarrow \mathrm{ZnO}+\mathrm{Mn}_{2} \mathrm{O}_{3}$

Para descarga total:

$\mathrm{Zn}+\mathrm{MnO}_{2}+2 \mathrm{H}_{2} \mathrm{O} \rightarrow \mathrm{Mn}(\mathrm{OH})_{2}+\mathrm{Zn}(\mathrm{OH})_{2}$

Mecanismo:

A eficiência de uma descarga na célula alcalina é limitada pela taxa de difusão iônica no catodo, pela taxa de difusão dos prótons no dióxido de manganês eletrolítico e pela prematura passivação do anodo de zinco. ${ }^{(33)}$

Durante a descarga de uma pilha cujo eletrólito é uma solução concentrada de hidróxido de potássio, ocorre formação do óxido de zinco através da reação: $\mathrm{Zn}^{2+}+2 \mathrm{OH}^{-} \rightarrow \mathrm{ZnO}+\mathrm{H}_{2} \mathrm{O}$ e a redução do $\mathrm{Mn}^{4+}$ a $\mathrm{Mn}^{3+}$. Os mecanismos que levam à descarga de dióxido de manganês ainda não são totalmente conhecidos da ciência e na busca desse conhecimento muitos estudos têm sido conduzidos. ${ }^{(34,)}$

A descarga da célula eletroquímica ocorre através da inserção de prótons e elétrons dentro da estrutura do dióxido de manganês ${ }^{(35)}$ e pode ser representada pela equação: $\mathrm{MnOz}+\mathrm{xH}^{+}+\mathrm{xe}^{-} \rightarrow \mathrm{MnOOH}$. A inserção do elétron é efetuada a partir do circuito externo para reduzir $\mathrm{Mn}^{4+}$ a $\mathrm{Mn}^{3+} \mathrm{e}$, para manter a neutralidade das 
cargas, prótons formados pela decomposição da água na interface sólido/eletrólito também são inseridos na estrutura.

A Figura 6 mostra esquematicamente o mecanismo de descarga do dióxido de manganês. ${ }^{(31)}$

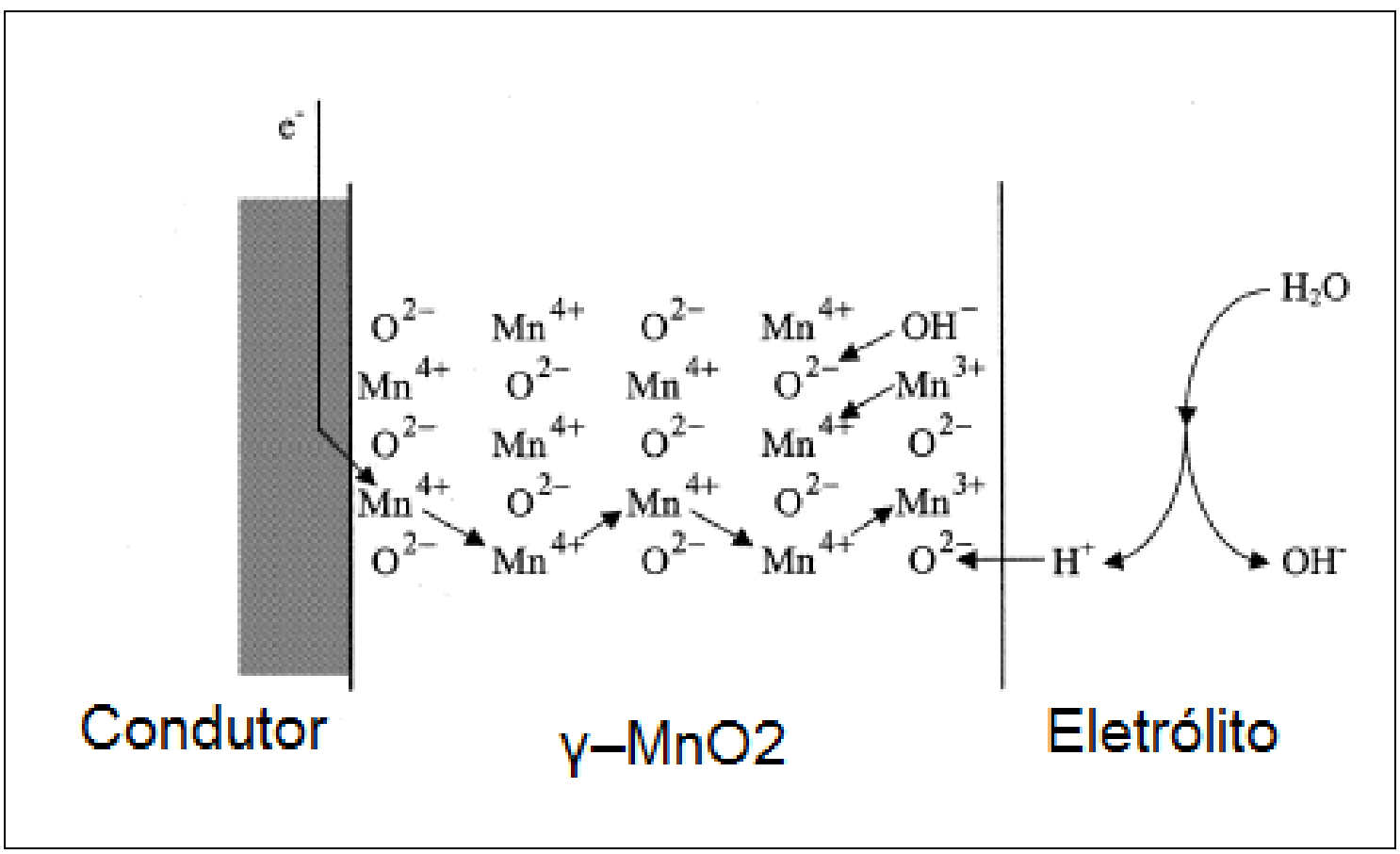

Figura 6 - Diagrama esquemático de movimento de prótons e elétrons durante a descarga. ${ }^{(36)}$

A difusão dos elétrons e prótons entre a superfície e o meio se dá através de defeitos da matriz cristalográfica por saltos entre sítios adjacentes (íons oxigênio para prótons e íons $\mathrm{Mn}^{4+}$ para elétrons). Esse fenômeno ocorre até que todo o $\mathrm{Mn}^{4+}$ seja reduzido a $\mathrm{Mn}^{3+}$, segundo a reação $\mathrm{MnO}_{2}+\mathrm{H}_{2} \mathrm{O}+\mathrm{e}^{-} \rightarrow \mathrm{MnOOH}+\mathrm{OH}^{-}$, seguida de nova redução das espécies $\mathrm{MnOOH}$ para $\mathrm{Mn}(\mathrm{OH})_{2}$, descrita na equação: $\mathrm{MnOOH}+\mathrm{H}_{2} \mathrm{O}+\mathrm{e}^{-} \rightarrow \mathrm{Mn}(\mathrm{OH})_{2}+\mathrm{OH}^{-}$. Segundo Kozawa e Yeager ${ }^{(37)}$, essa redução pode ser realizada segundo dois mecanismos: um envolve a redução no estado sólido de $\mathrm{MnOOH}$ a $\mathrm{Mn}(\mathrm{OH})_{2}$, enquanto o outro envolve a dissoluçãoreprecipitação na qual os íons $\mathrm{Mn}^{3+}$ se dissolvem dentro da solução, seguida por sua redução a íons $\mathrm{Mn}^{2+}$, que precipita quase imediatamente como $\mathrm{Mn}(\mathrm{OH})_{2}$, devido à solubilidade do $\mathrm{Mn}^{2+}$ ser dez vezes menor que a do $\mathrm{Mn}^{3+}$. 


\subsection{RECICLAGEM DE BATERIAS}

\subsubsection{Tipos de processos}

Muitos processos de recuperação de metais de pilhas e baterias são descritos na literatura científica. Esses processos usam basicamente três rotas distintas: a mineralúrgica, a pirometalúrgica e a hidrometalúrgica. ${ }^{(38,39,40)}$

A rota que utiliza as técnicas de processamento de minérios usa mecanismos físicos com base nas diferentes propriedades tais como densidade, condutividade, comportamento magnético etc. ${ }^{(40)}$ para a separação dos componentes das baterias. Muitas vezes essa rota é utilizada como um tratamento inicial da sucata para posterior processo de reciclagem..$^{(10)}$

A rota pirometalúrgica consiste no uso de alta temperatura (cerca de $\left.1000^{\circ} \mathrm{C}\right)^{(41)}$ para volatilizar metais contidos nas baterias e recuperá-los, depois, por condensação.

A rota hidrometalúrgica utiliza uma lixiviação ácida ou básica para solubilizar os metais contidos nas sucatas de pilhas e baterias e, em seguida, recupera-os da solução através de diferentes processos como precipitação ${ }^{(42,43)}$, eletrólise ${ }^{(39)}$, extração líquido - líquido ${ }^{(44)}$, dentre outros. Alguns desses processos estão resumidos na Tabela 8. 
Tabela 8 - Processos para reciclagem de pilhas e baterias. ${ }^{(10,40)}$

\begin{tabular}{lll}
\hline Processo & Rota utilizada no processo & Tipos de pilhas/baterias \\
\hline Sumitomo & Pirometalúgica & $\begin{array}{l}\text { Todos os tipos de pilhas } \\
\text { Não indicado para } \\
\text { baterias de NiCd }\end{array}$ \\
\hline Recytec & $\begin{array}{l}\text { Todos os tipos de pilhas } \\
\text { Hirometalúrgica, }\end{array}$ \\
& $\begin{array}{l}\text { Não indicado para } \\
\text { Mineralúrgica }\end{array}$ \\
\hline Atech & Basicamente Mineralúrgica de NiCd & Todos os tipos de pilhas \\
\hline Snam - Savam & Pirometalúrgica & Baterias NiCd \\
\hline Sab - Nife & Pirometalúrgica & Baterias NiCd \\
\hline Inmetco & Pirometalúrgica & Baterias NiCd \\
\hline Waelz & Pirometalúrgica & $\begin{array}{l}\text { Pilhas alcalinas que não } \\
\text { contém Hg }\end{array}$ \\
\hline TNO & Hidrometalúrgica & Pilhas e Baterias \\
\hline Accurec & Pirometalúrgica & Pilhas e Baterias \\
\hline
\end{tabular}

É interessante observar que os processos de reciclagem de pilhas e baterias podem ser específicos para processar apenas pilhas e baterias, ou podem reciclar esse material juntamente com outros tipos de materiais. ${ }^{(40)}$

\subsubsection{Recuperação do manganês}

O manganês pode ser recuperado de pilhas e baterias usadas através de uma rota hidrometalúrgica, em que o manganês da solução lixiviada pode ser obtido através da precipitação com carbonato. O precipitado de carbonato de manganês é filtrado e lavado com água e, após secagem, pode ser comercializado como matéria prima para a produção de manganês e de dióxido de manganês. ${ }^{(45)}$

Bartolozzi ${ }^{(41)}$ desenvolveu um processo totalmente hidrometalúrgico para a recuperação de zinco e de manganês de baterias usadas. Esse processo é constituído das seguintes etapas: lixiviação ácida com ácido sulfúrico $32 \%$; remoção do ferro, por precipitação com hidróxido de sódio a pH 3,7, amônia 32\% e pequenas quantidades de peróxido de hidrogênio; pré eletrólise da solução subseqüente para remoção de mercúrio, níquel e cádmio e, então, a pH 3,7, eletrólise para recuperação de zinco e manganês. 
A redução eletrolítica para a recuperação simultânea de zinco e de dióxido de manganês de pilhas alcalinas de zinco-carbono também foi investigada por Souza ${ }^{(46)}$. O método utilizado consistiu em tratamento físico das pilhas, lixiviação com ácido sulfúrico, purificação da solução lixiviada e, por fim, eletrólise para redução de zinco e oxidação de manganês.

Veloso et $\mathrm{al}^{(29)}$ propuseram uma rota hidrometalúrgica de separação seletiva de zinco e de manganês de pilhas alcalinas. A rota utilizada nessa reciclagem consiste das etapas de tratamento preliminar, seguidas de lixiviação neutra e ácida e de precipitação de zinco e de manganês, a partir do uso de hidróxidos como agentes precipitantes.

Uma rota hidrometalúrgica baseada na técnica de extração líquido-líquido, que usa Cyanex 272 como extrator, foi investigada para a separação seletiva de metais de valor, em particular zinco e manganês, de pilhas alcalinas ${ }^{(44)}$. Essa rota de reciclagem consistiu das seguintes etapas: desmantelamento criogênico, prétratamento do material interno, lixiviação com ácido sulfúrico e separação do metal por extração líquido-líquido.

A recuperação de manganês e de zinco nas formas $\mathrm{MnO}_{2}$ e $\mathrm{ZnO}$ de pilhas dos tipos $\mathrm{ZnO} / \mathrm{MnO}_{2}$ e alcalinas foi realizada através do tratamento da pasta eletrolítica, por fusão com $\mathrm{NaOH}$ ou com $\mathrm{KHSO}_{4}$. Afonso et al. ${ }^{(47)}$ obtiveram resultados promissores na separação de zinco e de manganês de outros componentes metálicos após a utilização desse processo.

Wolff et al. ${ }^{(48)}$ estudaram a viabilidade de se utilizar o dióxido de manganês presente nas pilhas Zinco-Carbono e alcalina na produção de agregado leve. $O$ trabalho consistiu primeiramente em se obter o resíduo de manganês presente nas pilhas através de lixiviação do $\mathrm{MnO}_{2}$ com ácido sulfúrico, filtração e posterior secagem. Esse resíduo, após ser triturado, foi misturado com vidro cálcico-sódico e solução de amido $10 \%$, na proporção $25 \mathrm{~g} / 25 \mathrm{~g} / 10 \mathrm{~mL}$, respectivamente. Com essa massa, foram preparados corpos de provas para análise. Concluiu-se que o resíduo que contém manganês pode ser sinterizado com vidro branco de embalagens descartáveis e que as pilhas zinco-carbono e alcalinas de manganês contém $\mathrm{MnO}_{2}$ em quantidade suficiente para a produção de agregado leve. 


\subsection{PRODUÇÃO DO DIÓXIDO DE MANGANÊS}

O minério de manganês, para ser utilizado na fabricação de pilhas, tem que, necessariamente, apresentar características específicas quanto a seus componentes e teores destes.

$\mathrm{Na}$ Tabela 9 figuram os teores mínimos e máximos de concentração dos componentes dos produtos de manganês na fabricação de baterias. ${ }^{(5)}$

Tabela 9 - Especificações para minérios de manganês usados para fabricação de baterias. ${ }^{(5)}$

\begin{tabular}{cc}
\hline $\begin{array}{c}\text { Elemento/ } \\
\text { composto }\end{array}$ & Teor (\%) \\
\hline $\mathrm{MnO}_{2}$ & $75-85$ \\
\hline $\mathrm{Mn}$ & $48-58$ \\
\hline $\mathrm{H}_{2} \mathrm{O}$ & $3-5$ \\
\hline $\mathrm{Fe}$ & $0,2-0,3$ \\
\hline $\mathrm{SiO}_{2}$ & $0,5-5,0$ \\
\hline $\begin{array}{c}\text { Impurezas } \\
\text { metálicas }\end{array}$ & $0,1-0,2$ \\
\hline
\end{tabular}

É possível extrair-se da natureza o minério de manganês que atenda às especificações acima, no entanto a demanda por esse material não é atendida apenas pelo minério in natura. Por isso, faz-se necessário que se produza o dióxido de manganês, por meio de processos químicos ou eletroquímicos, usando-se, para isso, quer o minério não próprio para uso in natura, quer outros diversos materiais. ${ }^{(24)}$

A produção do dióxido de manganês envolve custos maiores que a extração mineral, no entanto, essa síntese possibilita a obtenção de material de elevada pureza e melhor qualidade. Isso pode ser confirmado na

Tabela 10, em que figuram as especificações do dióxido de manganês eletrolítico. ${ }^{(49)}$ 
Tabela 10 - Especificações do dióxido de manganês eletrolítico. ${ }^{(49)}$

\begin{tabular}{lcc}
\hline \multicolumn{1}{c}{ Item } & $\begin{array}{c}\text { Grau Bateria } \\
\text { Alcalina }\end{array}$ & $\begin{array}{c}\text { Grau Bateria } \\
\text { Zinco - Carbono }\end{array}$ \\
\hline $\mathrm{MnO}_{2}(\mathrm{seco}) \% \min$ & 91 & 91 \\
\hline Umidade \%max & 2,0 & 3,0 \\
\hline $\mathrm{Fe} \mathrm{ppm} \mathrm{max}$ & 150 & 300 \\
\hline $\mathrm{Cu}$ ppm max & 5,0 & 5,0 \\
\hline $\mathrm{Pb}$ ppm max & 5,0 & 5,0 \\
\hline $\mathrm{Ni} \mathrm{ppm} \mathrm{max}$ & 5,0 & 5,0 \\
\hline $\mathrm{Co} \mathrm{ppm} \mathrm{max}$ & 5,0 & 5,0 \\
\hline $\mathrm{K} \mathrm{ppm} \mathrm{max}$ & 300 & -- \\
\hline $\mathrm{Mo} \mathrm{ppm} \mathrm{max}^{2-} \%$ max & 1,0 & -- \\
\hline $\mathrm{NH}_{4}{ }^{2-}$ ppm max & 1,3 & 1,3 \\
\hline Ácido clorídrico & 20,0 & 20,0 \\
insolúvel\%max & 0,10 & 0,10 \\
\hline Tamanho 100mesh \%min & 99 & 99 \\
\hline Tamanho 200mesh \%min & 90,0 & 90.0 \\
\hline Tamanho 325mesh \%min & 85 & 85 \\
\hline
\end{tabular}

\subsubsection{Produção do Dióxido de Manganês Químico (CMD)}

O dióxido de manganês químico tem sido sintetizado por meio de diferentes reações químicas ${ }^{(50,51)}$, tais como: decomposição térmica de sais de manganês ${ }^{(52)}$ (carbonato de manganês, $\mathrm{MnCO}_{3}$ ou nitrato de manganês, $\mathrm{Mn}\left(\mathrm{NO}_{3}\right)_{2}$ ), oxidação de hidróxido de manganês (II), desproporcionamento de compostos de $\mathrm{Mn}$ (III) seguido de oxidação com ozônio, oxidação de sais de manganês e redução de compostos de manganês com alta valência.

O método convencional para a produção do dióxido de manganês químico é desenvolvido por meio de uma rota de carbonato ${ }^{(53)}$, que consiste numa redução do minério de dióxido de manganês, seguida de uma lixiviação sulfúrica. Depois da remoção de impurezas por neutralização, com pH na faixa de 4- 6, e filtração, o manganês na solução poderá ser enviado à eletrólise para a produção de dióxido de manganês eletrolítico ou recuperado como carbonato de manganês pela adição de carbonato de amônio. O dióxido de manganês químico é obtido através do aquecimento do carbonato de manganês na presença de oxigênio ou de ar a aproximadamente $500^{\circ} \mathrm{C}$, segundo a reação: $\mathrm{MnCO}_{3}+1 / 2 \mathrm{O}_{2} \rightarrow \mathrm{MnO}_{2}+\mathrm{CO}_{2}$. $\mathrm{A}$ 
mistura de dióxido de manganês e carbonato de manganês é, posteriormente, lixiviada com ácido sulfúrico, para remoção de carbonato de manganês não oxidado e de sais de sódio e de potássio. Em seguida, procede-se à lavagem e à secagem para produção do dióxido de manganês químico (CMD - Chemical dioxide manganese) com $90 \%$ de $\mathrm{MnO}_{2}$.

\subsubsection{Produção do dióxido de manganês eletrolítico (DME)}

Um típico processo de síntese de dióxido do manganês eletrolítico a partir dos minerais pirolusita $\left(\mathrm{MnO}_{2}\right)$ e rodocrosita $\left(\mathrm{MnCO}_{3}\right)$ combina as tecnologias piro e hidrometalúrgica, o que inclui as seguintes etapas: redução do minério, lixiviação sulfúrica , purificação e eletrólise. ${ }^{(54)}$

O fluxograma completo das etapas do processo de obtenção do DME é mostrado na Figura $7 .{ }^{(5)}$ 


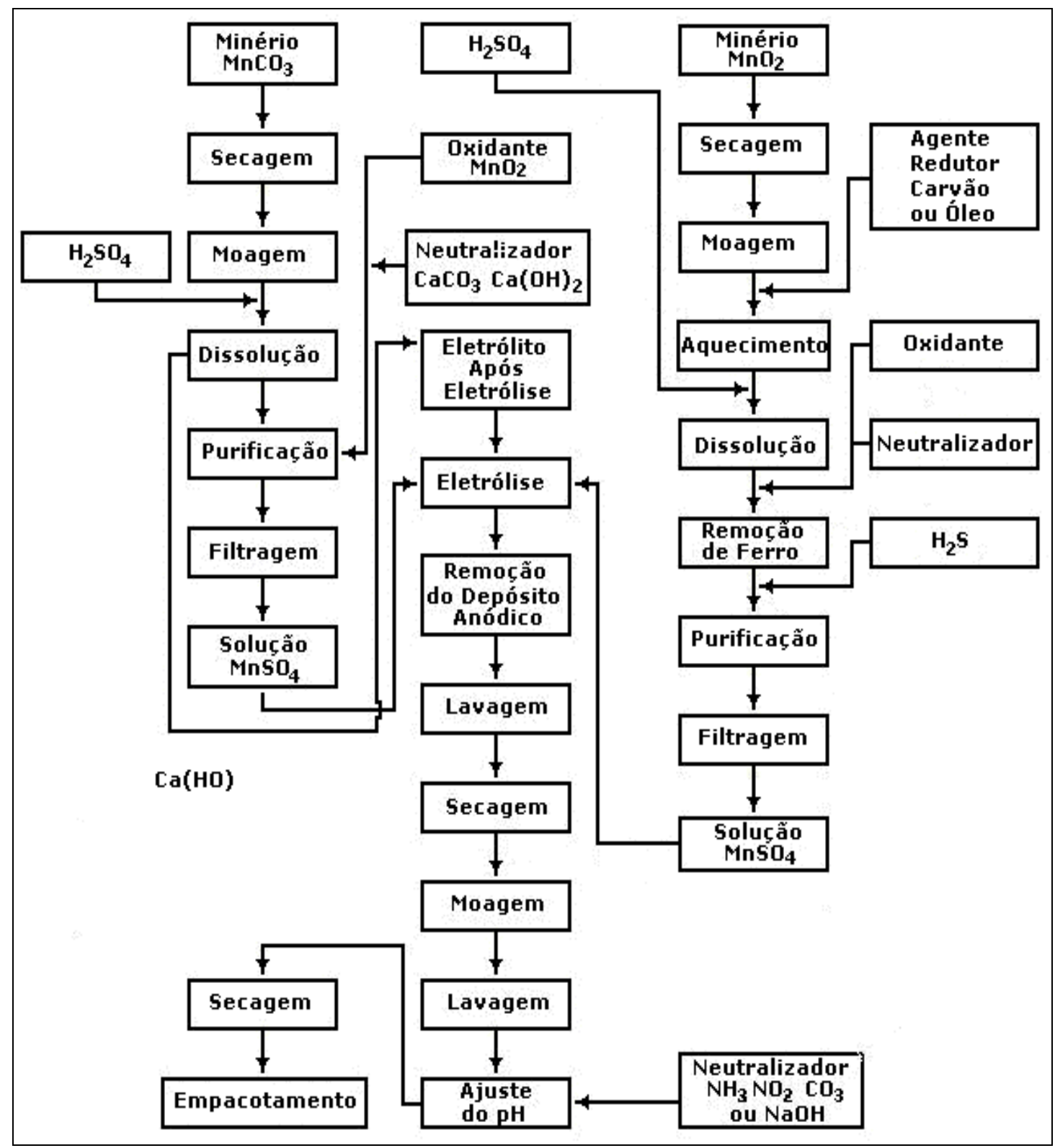

Figura 7 - Fluxograma do processo de obtenção do dióxido de manganês eletrolítico. ${ }^{(5)}$

A produção do dióxido de manganês eletrolítico com base em pirolusita compreende quatro estágios. ${ }^{(55,56)}$

- redução - consiste na redução parcial do dióxido natural de manganês, que é insolúvel em ácido, para óxido manganoso, que é solúvel em ácido, conforme a reação: $2 \mathrm{MnO}_{2}+\mathrm{C} \rightarrow 2 \mathrm{MnO}+\mathrm{CO}_{2}$;

- lixiviação ácida - consiste em se misturar o minério em pó ao ácido sulfúrico para dissolução do manganês, segundo a reação: $\mathrm{MnO}+2 \mathrm{H}^{+} \rightarrow \mathrm{Mn}^{2+}+\mathrm{H}_{2} \mathrm{O}$; seguida de purificação. 
- eletrólise - para obtenção do DME, segundo a reação:

$\mathrm{Mn}^{2+}+2 \mathrm{H}_{2} \mathrm{O} \rightarrow \mathrm{MnO}_{2}+2 \mathrm{H}^{+}+\mathrm{H}_{2}$;

- adição de calcário em pó para neutralização do excesso de ácido e purificar a solução de manganês.

O dióxido de manganês eletrolítico também pode ser produzido por oxidação anódica de solução aquecida de sulfato de manganês II em meio ácido, com eletrodos inertes. ${ }^{(18,34,49)}$ As reações envolvidas nesse processo são: oxidação dos íons manganosos $\left(\mathrm{Mn}^{2+}\right)$, para produção do dióxido de manganês no anodo e redução dos íons hidrogênio $\left(\mathrm{H}^{+}\right)$no catodo, com geração de gás hidrogênio $\left(\mathrm{H}_{2}\right)$.

Reação Anódica: $\mathrm{Mn}^{2+}+2 \mathrm{H}_{2} \mathrm{O} \rightarrow \mathrm{MnO}_{2}+4 \mathrm{H}^{+}+2 \mathrm{e}^{-}$

Reação Catódica: $2 \mathrm{H}^{+}+2 \mathrm{e}^{-} \rightarrow \mathrm{H}_{2}^{\uparrow}$

O mecanismo de deposição do dióxido de manganês é representado pela reação global: $\mathrm{Mn}^{2+}+2 \mathrm{H}_{2} \mathrm{O} \rightarrow \mathrm{MnO}_{2}+2 \mathrm{H}^{+}+\mathrm{H}_{2}{ }^{\uparrow}$. No entanto, segundo Rodrigues, Munichandraiah e Shukla ${ }^{(57)}$, é improvável que essa reação ocorra em uma única etapa, devido aos seguintes fatores:

i) o estado de oxidação do manganês aumenta de $2^{+}$a $4^{+}$e é improvável que os dois elétrons sejam transferidos em uma única etapa;

ii) para a formação do $\mathrm{MnO}_{2}$, a oxidação da molécula de água deve ocorrer concomitantemente com a oxidação de $\mathrm{Mn}^{2+}$.

Esses pesquisadores propuseram o seguinte mecanismo para a deposição do dióxido de manganês: ${ }^{(57)}$

Etapa1: Difusão dos íons $\mathrm{Mn}^{2+}$ da solução para a superfície do eletrodo;

$\mathrm{Mn}^{2+}{ }_{\text {sol. }} \rightarrow \mathrm{Mn}^{2+}$ superfície 
Etapa 2: Oxidação do $\mathrm{Mn}^{2+}$ a $\mathrm{Mn}^{3+}$ na superfície do eletrodo;

$\mathrm{Mn}^{2+}{ }_{\text {sperficie }} \rightarrow \mathrm{Mn}^{3+}{ }_{\text {ads }}+\mathrm{e}^{-}$

Etapa 3: Oxidação da água, produzindo radicais $\mathrm{OH}$ adsorvidos;

$\mathrm{H}_{2} \mathrm{O} \rightarrow \mathrm{OH}_{\text {ads }}+\mathrm{H}^{+}+\mathrm{e}^{-}$

Etapa 4: Reação de desproporcionamento do íon $\mathrm{Mn}^{3+}$, produzindo os íons $\mathrm{Mn}^{2+} \mathrm{e}$ $\mathrm{Mn}^{4+}$ no estado adsorvido;

$2 \mathrm{Mn}^{3+}{ }_{\text {ads }} \rightarrow \mathrm{Mn}^{2+}{ }_{\text {dds }}+\mathrm{Mn}^{4+}{ }_{\mathrm{ads}}$

Ou hidrólise do íon $\mathrm{Mn}^{3+}$, formando uma camada intermediária de $\mathrm{MnOOH}$, que na sequência é oxidado a $\mathrm{MnO}_{2}$;

$\mathrm{Mn}^{3+}{ }_{\text {ads }}+2 \mathrm{H}_{2} \mathrm{O} \rightarrow \mathrm{MnOOH}+3 \mathrm{H}^{+}$

$\mathrm{MnOOH} \rightarrow \mathrm{MnO}_{2}+\mathrm{H}^{+}+\mathrm{e}^{-}$

Etapa 5: Oxidação do íon $\mathrm{Mn}^{2+}$ e sua combinação com a $\mathrm{OH}_{\text {ads }}$ formada na etapa 3 , resultando em $\mathrm{MnO}_{2}$;

$\mathrm{Mn}^{2+}$ ads $+2 \mathrm{OH}_{\mathrm{ads}} \rightarrow \mathrm{MnO}_{2}+2 \mathrm{H}^{+}$

Etapa 6: Íons $\mathrm{Mn}^{4+}$ ads formados na etapa 4 combinam-se com $\mathrm{H}_{2} \mathrm{O}$, levando à formação de $\mathrm{MnO}_{2}$ na superfície do eletrodo.

$\mathrm{Mn}^{4+}{ }_{\text {ads }}+2 \mathrm{H}_{2} \mathrm{O} \rightarrow \mathrm{MnO}_{2}+4 \mathrm{H}^{+}$

Um esquema básico de reações para a formação eletroquímica do dióxido de manganês, como o mostrado abaixo, é encontrado em diversos artigos científicos. ${ }^{(56)}$ 


$$
\begin{aligned}
& 2 \mathrm{Mn}^{2+} \rightarrow 2 \mathrm{Mn}^{3+}+2 \mathrm{e}^{-} \\
& 2 \mathrm{Mn}^{3+} \rightarrow \mathrm{Mn}^{2+}+\mathrm{Mn}^{4+} \\
& \mathrm{Mn}^{4+}+2 \mathrm{H}_{2} \mathrm{O} \rightarrow \mathrm{MnO}_{2}+4 \mathrm{H}^{+}
\end{aligned}
$$

\subsubsection{Condições de eletrólise para produção de DME}

As características do dióxido de manganês eletrolítico produzido e o rendimento dependem de parâmetros tais como: natureza dos reagentes, $\mathrm{pH}$ e temperatura do meio reacional, duração do aquecimento, material do eletrodo, presença de impurezas e densidade de corrente durante o processo. ${ }^{(58)}$

A natureza do eletrólito influencia nas propriedades físicas, químicas e eletrolíticas do produto final. O uso, como eletrólito, de solução de sulfato de manganês em ácido sulfúrico é o método convencional de preparação do dióxido de manganês eletrolítico. ${ }^{(55)}$

O emprego frequente do sulfato de manganês, apesar de sua condutividade eletrolítica ser inferior à do cloreto e à do nitrato de manganês, se deve ao fato de apresentar vantagens como $^{(55)}$ : os problemas de corrosão são minimizados; o aquecimento do eletrólito pode ser feito em recipiente de chumbo; um neutralizante secundário, tal como cal, pode ser convenientemente utilizado para que ocorra a máxima extração do manganês, o chumbo e suas ligas podem ser empregados como eletrodo. Além disso, com a utilização do sulfato de manganês, obtém-se, no processo, uma alta eficiência de corrente.

A adição de ácido sulfúrico à solução de sulfato de manganês aumenta a eficiência de corrente no processo de obtenção do dióxido de manganês eletrolítico. Essa eficiência é ainda maior quando a razão entre as concentrações de ácido sulfúrico e de sulfato de manganês é cerca de $0,2{ }^{(15)}$

O dióxido de manganês é obtido na forma sólida a uma densidade de corrente 0,7-1,2 $\mathrm{A} \mathrm{dm}^{-2}$, em temperaturas de 90-95ํㅡ e em meios moderadamente ácidos $(0,5-1,0 \mathrm{~mol} / \mathrm{L})$. Nessas condições, obtêm-se os melhores rendimentos; em torno 
de 90 a 95\%. Em virtude do aumento da concentração do ácido o rendimento diminui, devido principalmente ao atraso da formação dos íons decorrentes da reação de desproporcionamento dos íons manganês (III) e posterior formação dos íons manganês (IV) na reação de hidrólise. ${ }^{(59)}$ Segundo Ghaemi e Binder ${ }^{(58)}$, é evidente que o valor de $\mathrm{pH}$ do banho eletrolítico é um fator determinante no processo, uma vez que íons de hidrogênio livres desempenham um importante papel no mecanismo de deposição do DME.

A concentração dos íons manganês perto do anodo e a densidade de corrente (elétrons disponíveis) também exercem uma influência sobre o processo de deposição. O decréscimo da eficiência de corrente é uma consequência do aumento na densidade de corrente anódica. Como se pode esperar, os valores mais baixos são obtidos quando a densidade de corrente média é elevada. Em alto potencial anódico, a eletrólise da água é ativada. Isso gera evolução de oxigênio, que, em maior ou menor grau, pode diminuir a eficiência de corrente e inibir a deposição de DME ou competir com a mesma. ${ }^{(60)}$

A temperatura do banho eletrolítico é outro fator importante no processo eletroquímico do dióxido de manganês, pois tem efeito sobre a velocidade de reações e exerce um papel fundamental sobre a estrutura cristalina das fases formadas, influenciando nas propriedades físicas e químicas do dióxido de manganês formado. ${ }^{(15)}$

Dióxidos de manganês produzidos em baixas temperaturas, como $60^{\circ} \mathrm{C}$ mostram capacidade de carga inferior quando comparados com os dióxidos de manganês produzidos a temperaturas elevadas, maiores ou iguais a $90 \mathrm{C}{ }^{\left({ }^{(61)}\right.} \mathrm{O}$ maior desempenho durante o ciclo de cargas e descargas do DME produzido em temperaturas elevadas é conseqüência da estabilização da estrutura cristalina. ${ }^{(58)}$

Diferentes materiais podem ser utilizados como anodo para a preparação do dióxido de manganês. Os mais utilizados são: liga de chumbo, grafite e titânio.

A liga de chumbo-antimônio é geralmente resistente ao eletrólito sulfato e pode ser reutilizada em execuções sucessivas através da refusão e reformulação do anodo. Porém apresenta algumas desvantagens tais como a intolerância de contaminação no eletrólito de cloreto, mesmo em níveis de ppm, e a contaminação do produto final com metais pesados, que é prejudicial durante a aplicação do DME nas baterias. ${ }^{(62)}$ 
O anodo de grafite é vantajoso por apresentar baixo custo e por não sofrer passivação mesmo para altas densidades de corrente. No entanto, é extremamente difícil evitar o desgaste e danos do substrato de grafites decorrentes da aplicação de altas densidades de corrente, do aumento da concentração do ácido e da remoção do dióxido de manganês depositado que penetra na superfície do anodo. A contaminação do produto final pelo grafite reduz a pureza do DME. ${ }^{(62)}$

O metal titânio tem sido considerado o material mais adequado para uso como anodo na produção do dióxido de manganês. Esse material apresenta como vantagens: estabilidade dimensional, alta resistência à corrosão (não só na presença de ácido sulfúrico, mas também na de outros ácidos) e a obtenção de um DME de melhor qualidade. O depósito formado é pouco aderente e, por isso, sua remoção é facilitada, o que evita a contaminação e o desgaste do anodo. ${ }^{(62)}$

Um dos problemas da utilização de anodos de titânio é a restrição quanto à densidade de corrente anódica que pode ser aplicada, que deve apresentar valores baixos (de 0,8 a $1,1 \mathrm{~A} \cdot \mathrm{dm}^{-2}$ ). ${ }^{(63}$ Entretanto, a principal desvantagem da utilização do titânio como anodo para produção do DME é a ocorrência da passivação, que é a formação de um filme de óxido de espessura superior a $10 \mathrm{~nm}$ e estável mesmo em meio ácido. ${ }^{(15)}$ Esse fenômeno pode reduzir a quantidade de DME produzido ou, até, inviabilizar a eletrólise.

1.5.2.2 Influência de impurezas na produção de DME

A remoção de impurezas metálicas indesejáveis, como ferro, alumínio, potássio, cobalto, dentre outras, é necessária para a produção de um DME com melhores propriedades físicas e químicas. A presença dessas impurezas na solução eletrolítica pode influenciar no mecanismo de deposição e na atividade eletroquímica do DME. ${ }^{(64)}$

A pureza do DME é um fator importante para o bom desempenho das pilhas e baterias. Impurezas, mesmo em níveis baixos, podem ter um impacto sobre 0 comportamento eletroquímico do $\mathrm{MnO}_{2}$. Em alguns casos, essas espécies estranhas degradam o desempenho catódico nas pilhas ou afetam outros componentes tais 
como o anodo. O dióxido de manganês para uso em baterias deve apresentar menos que $0,001 \%$ de $\mathrm{Sb}, \mathrm{Pb}, \mathrm{Sn}, \mathrm{Ni}, \mathrm{Co}, \mathrm{Cu}$, Ge e menos que $1 \%$ de Fe. ${ }^{(61)}$

A presença de íons ferrosos como impureza resulta na diminuição da eficiência de corrente, devido à formação da reação $\mathrm{Fe}^{2+} / \mathrm{Fe}^{3+}{ }^{3+}{ }^{(64)} \mathrm{A}$ presença do íon ferroso na solução eletrolítica diminui a taxa de difusão dos íons manganosos, devido à reação de oxidação do íon ferroso a férrico. ${ }^{(65)}$

A adição de $10 \mathrm{~g} / \mathrm{L}$ de sulfato de magnésio não influencia na deposição do dióxido de manganês, enquanto quantidade excessivas causam formação de microestruturas grosseiras e adsorção de pequenas quantidades de sulfato de magnésio na grade do $\mathrm{MnO}_{2}{ }^{(55)}$

A remoção de potássio é necessária para a produção do dióxido de manganês eletrolítico porque sua presença durante a eletrólise promove a formação da variedade alotrópica $\alpha-\mathrm{MnO}_{2}$ a qual não é grau bateria. ${ }^{(3)}$

Kao, Weibel e $\operatorname{Root}^{(66)}$ estudaram a influência do íon potássio na eletrodeposição e na eletroquímica do dióxido de manganês eletrolítico e comprovaram que a incorporação do potássio no DME e a formação da fase $\alpha-\mathrm{MnO}_{2}$ aumentam com o aumento da concentração do íon na solução eletrolítica. Também foi constatado que a presença da fase $\alpha-\mathrm{MnO}_{2}$, mesmo em quantidade pequena $(>3 \%)$, pode ter efeitos observáveis na redução eletroquímica do DME. A voltametria cíclica e a cronopotenciometria mostraram variação em picos catódicos que podem ser correlacionados com o aumento do componente $\alpha-\mathrm{MnO}_{2}$ do DME.

$\mathrm{O}$ efeito dos cátions $\mathrm{NH}_{4}{ }^{+}, \mathrm{K}^{+}, \mathrm{Zn}^{2+}, \mathrm{Mg}^{2+}$ e $\mathrm{Al}^{3+}$ sobre as características de descarga do $\mathrm{MnO}_{2}$ em eletrólito de $\mathrm{NH}_{4} \mathrm{Cl}$ foi investigado por Kozawa e Vosburg ${ }^{(67)}$, que verificaram que as curvas de descarga dos eletrodos com presença de cátions $\mathrm{Zn}^{2+}, \mathrm{Mg}^{2+} \mathrm{e} \mathrm{Al}^{3+}$ são pouco diferentes das dos eletrodos que não apresentam esses cátions. No entanto, a presença de cátions $\mathrm{NH}_{4}{ }^{+}$ou $\mathrm{K}^{+}$determina que a curva de descarga seja consideravelmente diferente da normal.

Estudos indicam que a inclusão de titânio de até $0,8 \%$ em peso no produto DME, através de um banho eletrolítico contendo TiS ou TiO, melhora o desempenho de descarga e recarga. ${ }^{(55)}$

Tem sido demonstrado que a adição de cátions como sódio, cálcio e amônio em quantidades vestigiais não influencia na deposição do dióxido de manganês e se obtém, em todos os casos, a variedade alotrópica $\gamma-\mathrm{MnO}_{2}{ }^{\left({ }^{(3)}\right.}$ 
Era, Takehara e Yoshizawa ${ }^{(68)}$ investigaram o efeito do chumbo contido no dióxido de manganês sobre capacidade de descarga durante o armazenamento de células secas. Verificaram que teores de $0,1 \%$ ou superiores de $\mathrm{Pb}$ não influenciam na taxa de deterioração do dióxido de manganês mantido na solução de uma célula normal da pilha Leclanché. Foi constatado também que a adição de íons $\mathrm{Pb}^{2+}$ na solução da pilha seca diminui a corrosão do Zn. Os íons $\mathrm{Cu}^{2+}, \mathrm{Na}^{+}, \mathrm{Sb}^{3+}$ e $\mathrm{As}^{3+}$ também foram investigados e mostraram ser muito prejudiciais por acelerar a corrosão do zinco. Essa corrosão, contudo, é reprimida pela presença do íon $O$ limite permitido de chumbo em baterias dos tipos. alcalina-manganês e zincomanganês é de até $0,1 \%$ em peso ${ }^{(69)}$

$\mathrm{Li}$, Jiang.e Huang ${ }^{(70)}$, citam a descrição de um processo alternativo para a produção do $\mathrm{DME}$ em que Íons $\mathrm{Ag}^{+}$são utilizados como eletrocatalisador para oxidação de íons $\mathrm{Mn}^{2+}$. Nessa técnica, o dióxido de manganês ativado pode ser preparado a alta eficiência e alta densidade de corrente, à temperatura ambiente. $\mathrm{O}$ DME formado na presença do cátion prata torna-se mais ativo, e exibe uma maior capacidade de recarga. Dessa forma, os íons $\mathrm{Ag}^{+}$, que poderiam constituir uma impureza, funcionam como aceleradores e facilitadores do processo, não se agregando ao produto. 


\section{OBJETIVOS}

O desenvolvimento dessa pesquisa objetiva a:

a) verificar a viabilidade técnica de se recuperar o manganês, na forma do dióxido de manganês, por meio de eletrólise, de solução resultante do tratamento hidrometalúrgico de pilhas e baterias exauridas, que apresenta em sua composição, além de manganês, íons de cálcio, titânio, cobalto, níquel e chumbo;

b) estudar $\mathrm{o}$ efeito da densidade de corrente e do $\mathrm{pH}$ no processo de recuperação do dióxido de manganês pelo processo de eletrodeposição;

c) caracterizar as amostras de dióxido de manganês obtidas no processo. 


\section{MATERIAIS E MÉTODOS}

A proposta deste trabalho é obter o dióxido de manganês eletrolítico a partir de solução sintética preparada com base nos resultados obtidos por Espinosa ${ }^{(10)}$, em pesquisa que teve como objetivo caracterizar uma amostra de pilhas e baterias usadas e estudar os principais parâmetros para uma rota pirometalúrgica e hidrometalúrgica de obtenção dos metais nelas contidos. A referida pesquisa se consistiu das seguintes etapas e respectivos objetivos e/ou resultados:

- segregação e classificação das baterias - resultou em amostras representativas de $10 \mathrm{~kg}$ com as composições aproximadas da amostra global;

- moagem - resultou em amostras com tamanho inferior a 3,360mm;

- briquetagem - objetivando a aumentar a quantidade de material a ser colocado no forno durante o ensaio de redução;

- redução em atmosfera inerte de argônio a $1000^{\circ} \mathrm{C}$ por $4 \mathrm{~h}$ - objetivando a eliminação dos metais voláteis $(\mathrm{Zn}, \mathrm{Cd}$ e Hg) da amostra e a redução dos óxidos de manganês em MnO;

- separação magnética: objetivando a recuperação de pelo menos $80 \%$ de ferro e separação da fração não magnética;

- lixiviação da fração não magnética com solução de ácido sulfúrico 2 mol/L objetivando solubilizar os metais contidos;

- precipitação da seletiva com $\mathrm{NaOH} 2 \mathrm{~mol} / \mathrm{L}$ - objetivando a estudar o efeito do $\mathrm{pH}$ na precipitação do material lixiviado,

- precipitação com oxalato de amônio $70^{\circ} \mathrm{C}$ - objetivando estudar o efeito da adição da substância na precipitação do manganês lixiviado.

A análise química realizada nas amostras após redução e separação magnética revelou que o manganês é o principal constituinte $(62,9 \%)$ da fração não magnética. Foi também verificado na etapa hidrometalúrgica que $88 \%$ dessa fração se solubiliza em ácido sulfúrico, o que resulta numa solução com um alto teor em íons manganosos (115.300mg/L).

Esse achado despertou o interesse por se pesquisar a viabilidade da recuperação do manganês contido nessa solução, através do processo eletrolítico, 
para a obtenção do dióxido de manganês eletrolítico. É a partir desse ponto que tem início esta pesquisa.

Para este trabalho, devido à indisponibilidade de quantidade suficiente da solução resultante da pesquisa anterior, foi necessário o preparo de uma solução sintética. Antes do preparo dessa solução foi feita uma análise dos resultados encontrados para as etapas de lixiviação e precipitação com $\mathrm{NaOH}$ do trabalho de Espinosa ${ }^{(36)}$, para a posterior definição da composição da solução.

Foi verificado no trabalho de Espinosa que, dos metais presentes $(\mathrm{Al}, \mathrm{Ca}, \mathrm{Ce}$, $\mathrm{Co}, \mathrm{Cu}, \mathrm{Fe}, \mathrm{K}, \mathrm{La}, \mathrm{Mn}, \mathrm{Ni}, \mathrm{Pb}$ e Ti) na fração não magnética,

- o cobre normalmente é insolúvel em meio sulfúrico sem oxidante, portanto não está presente na solução após lixiviação com ácido sulfúrico (isso ficou comprovado através da análise da fração não solúvel);

- os compostos de Terras Raras podem ser precipitados na faixa de $\mathrm{pH}$ entre 0,3 e 1,0 ,

- o alumínio e o ferro podem ser precipitados a pH acima de 3,5.

Observando-se esses resultados, verifica-se a possibilidade de remoção desses metais da solução através da precipitação com $\mathrm{NaOH}$. Restam, portanto, os seguintes íons metálicos na solução: $\mathrm{Ca}, \mathrm{Co}, \mathrm{K}, \mathrm{Mn}, \mathrm{Ni}, \mathrm{Pb}$ e Ti.

A literatura relata que o potássio interfere na eletrodeposição e na propriedade eletroquímica do dióxido de manganês ${ }^{(3,64)}$. Portanto, deve ser removido da solução antes do processo de eletrólise. Isso é normalmente alcançado pela precipitação de jarosita, processo para qual sulfato férrico é normalmente adicionado. A reação de precipitação de jarosita pode ser representada pela equação: ${ }^{(71)}$

$\mathrm{K}^{+}+3 \mathrm{Fe}^{3+}+2 \mathrm{SO}_{4}{ }^{2-}+6 \mathrm{H}_{2} \mathrm{O} \rightarrow \mathrm{KFe}_{3}\left(\mathrm{SO}_{4}\right)_{2}(\mathrm{OH})_{6} \downarrow+6 \mathrm{H}^{+}$

Outro processo que pode ser utilizado para remoção do potássio é a inclusão da etapa de lixiviação neutra (com água) anterior a de lixiviação ácida para remoção dos elementos solúveis em água. ${ }^{(29)}$.

A partir dessas considerações, a composição dos íons metálicos na solução preparada para este trabalho ficou assim definida: $\mathrm{Ca}, \mathrm{Co}, \mathrm{Mn}, \mathrm{Ni}, \mathrm{Pb}$ e Ti. As concentrações dos íons foram determinadas a partir dos resultados da análise química obtida no trabalho de Espinosa. ${ }^{(10)} \mathrm{O}$ pH definido para a solução inicial foi de 0,30 , devido ao fato de a reação de deposição do dióxido de manganês ocorrer em eletrólitos ácidos concentrados. ${ }^{59)}$ 
A parte experimental desta pesquisa partiu, portanto, da preparação da solução sintética, que seguiu os ensaios: de eletrólise, para a obtenção do dióxido de manganês, da variação nos parâmetros densidade de corrente e $\mathrm{pH}$ e da caracterização dos produtos obtidos.

\subsection{PREPARAÇÃO DA SOLUÇÃO ELETROLÍTICA}

Os reagentes utilizados na preparação da solução foram sulfato de cobalto heptaidratado (Merck P.A), sulfato manganoso monoidratado (Proquimios P.A), sulfato de cálcio diidratado (Carlo Erba P.A), sulfato de níquel hexaidratado (Vetec P.A), sulfato de chumbo (Aldrich P.A), óxido de titânio IV (Vetec) e ácido sulfúrico (Vetec).

A solução foi preparada adicionando-se os seguintes reagentes: $\mathrm{MnSO}_{4} \cdot \mathrm{H}_{2} \mathrm{O}$, $\mathrm{CoSO}_{4} .7 \mathrm{H}_{2} \mathrm{O}, \mathrm{CaSO}_{4} .2 \mathrm{H}_{2} \mathrm{O}$, de $\mathrm{NiSO}_{4} .6 \mathrm{H}_{2} \mathrm{O}, \mathrm{PbSO}_{4}, \mathrm{H}_{2} \mathrm{SO}_{4}$ concentrado, solução de titânio e água destilada suficiente para completar um litro da solução. A quantidade adicionada de cada reagente foi calculada para fornecer a concentração de íons e o valor de $\mathrm{pH}$ correspondente à solução encontrada no trabalho de Espinosa. ${ }^{(10)}$

A Tabela 11 fornece os valores das concentrações em $\mathrm{mg} / \mathrm{L}$ dos íons metálicos e o pH final da solução eletrolítica

Tabela 11 - Composição da solução eletrolítica.

\begin{tabular}{lccc}
\hline Reagentes & Íon metálico & $\begin{array}{c}\text { Conc. do íon } \\
\text { (mg/L) }\end{array}$ & $\mathrm{pH}$ \\
\hline $\mathrm{MnSO}_{4} \cdot \mathrm{H}_{2} \mathrm{O}$ & $\mathrm{Mn}^{2+}$ & 115300 & \\
\hline $\mathrm{CoSO}_{4} \cdot 7 \mathrm{H}_{2} \mathrm{O}$ & $\mathrm{Co}^{2+}$ & 630 & \\
\hline $\mathrm{CaSO}_{4} \cdot 2 \mathrm{H}_{2} \mathrm{O}$ & $\mathrm{Ca}^{2+}$ & 270 & 0,30 \\
\hline $\mathrm{NiSO}_{4} 6 \mathrm{~N}_{2} \mathrm{O}$ & $\mathrm{Ni}^{2+}$ & 3000 & \\
\hline $\mathrm{PbSO}_{4}$ & $\mathrm{~Pb}^{2+}$ & 20 & \\
\hline $\mathrm{TiO}_{2}$ & $\begin{array}{c}\text { Solução ácida } \\
\text { de TiO }\end{array}$ & 400 & \\
\hline
\end{tabular}




\subsection{ENSAIOS DE ELETRÓLISE}

Fizeram parte dessa etapa a definição da configuração ideal da célula, a montagem da mesma, a preparação de reagentes e a definição da quantidade de eletrodos a serem utilizados e sua área superficial.

Foram realizados experimentos até que se definissem os aparatos e métodos que proporcionassem a obtenção de melhores resultados. A partir dessas definições, procedeu-se a uma eletrólise da solução estudada para que se verificasse ser realmente possível a obtenção do DME a partir dela. Esse procedimento será referenciado a seguir como ensaios preliminares para obtenção do dióxido de manganês (DME) e o seu produto, parâmetro inicial para as diferentes análises, será tratado como DME preliminar.

Somente após a constatação de que é possível se recuperar o manganês a partir do processo eletrolítico, teve início a sequência de experimentos em que foram levadas em conta as variações de $\mathrm{pH}$ e de densidade de corrente e seus reflexos nas características do DME obtido.

\subsubsection{Ensaio Preliminar para Obtenção do Dióxido de Manganês Eletrolítico}

A célula utilizada durante os processos eletrolíticos foi constituída por um béquer de $250 \mathrm{~mL}$ de capacidade, para o qual se confeccionou uma tampa com aberturas para: dois contra eletrodos, um eletrodo de trabalho, um termômetro e um condensador, conforme mostrado na Figura 8 e na Figura 9. 


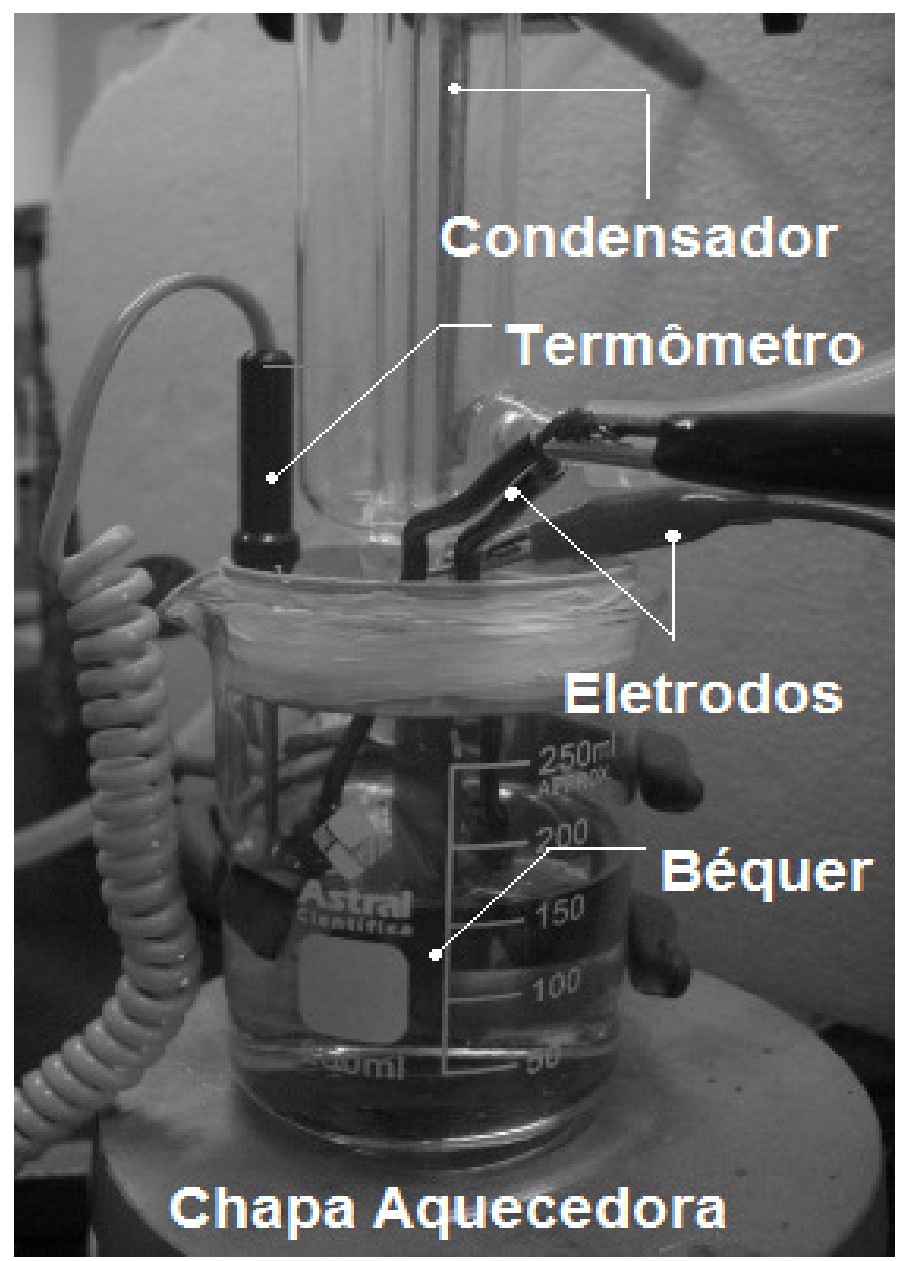

Figura 8- Foto da célula eletroquímica desenvolvida para produção do DME.

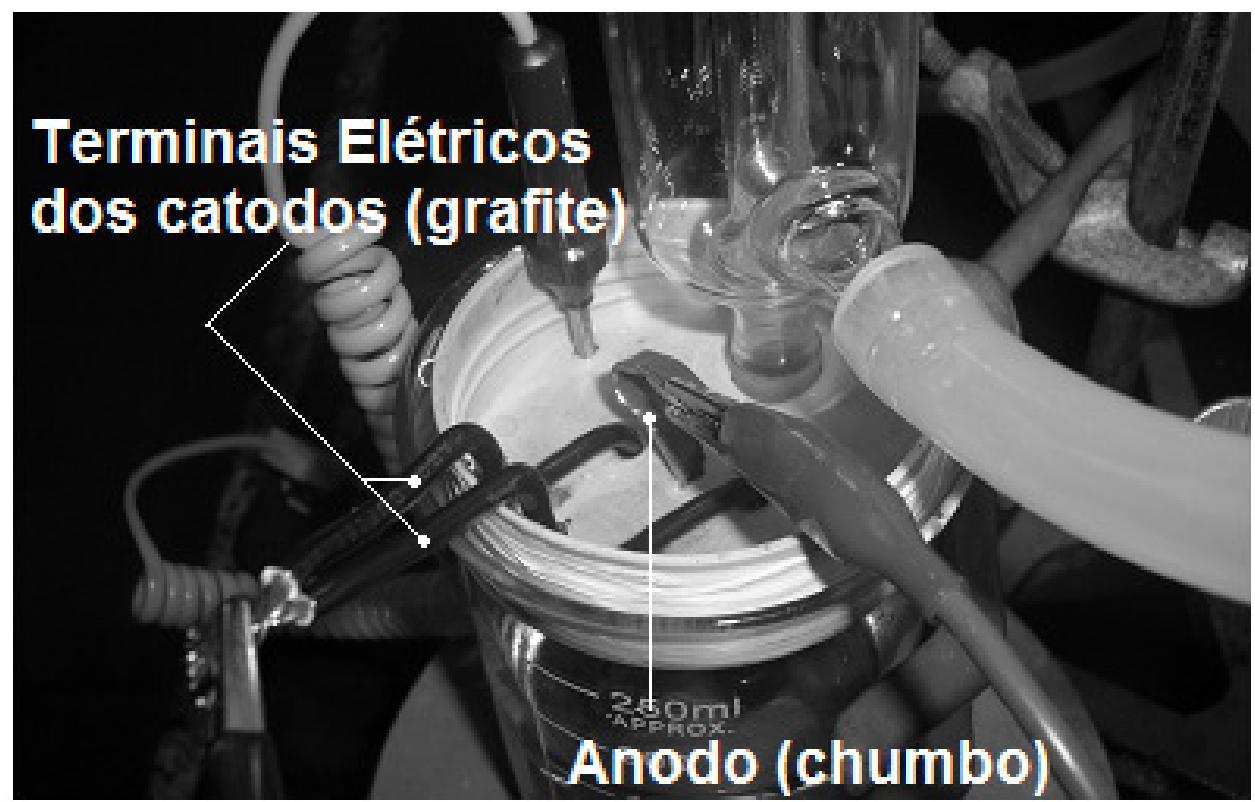

Figura 9- Detalhamento da tampa da célula eletrolítica. 
Utilizou-se uma chapa de chumbo de 5,0 cm de altura, 2,0 cm de largura e $0,1 \mathrm{~cm}$ de espessura como eletrodo de trabalho (anodo) e dois grafites com 2,5 cm de altura, 1,0 cm de largura e 0,5 de espessura como contra eletrodo (catodo), conforme mostrado a Figura 10.

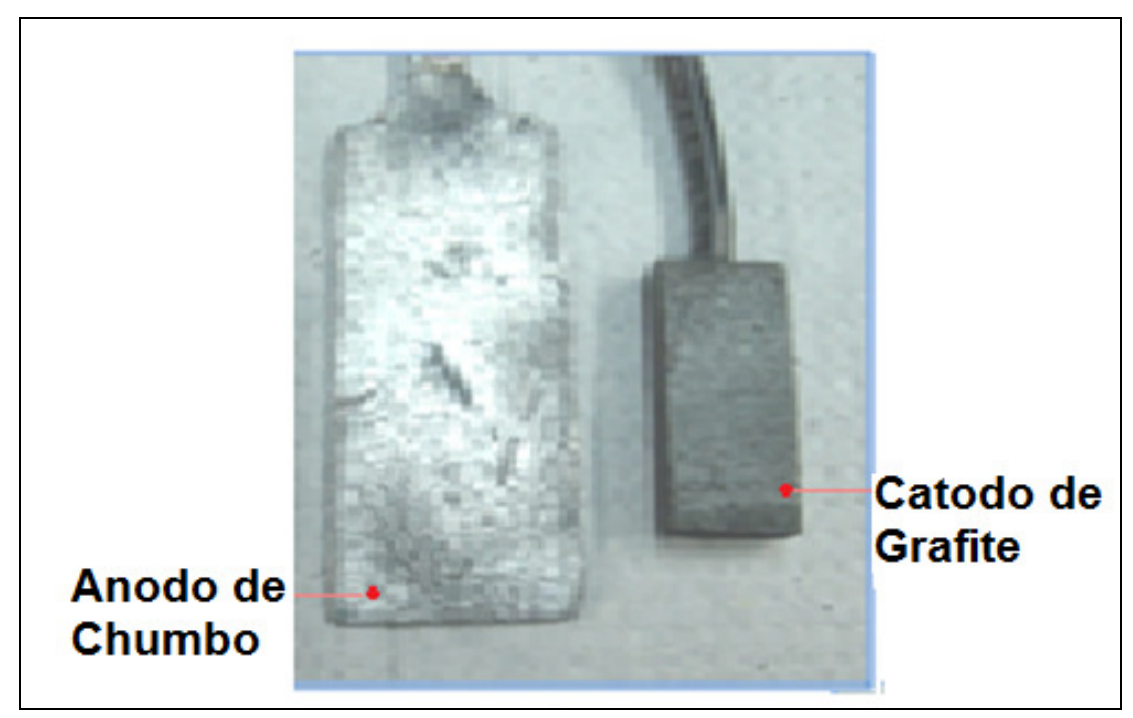

Figura 10 - Foto do eletrodo de trabalho (anodo) e do contra-eletrodo (catodo).

Um volume de $150 \mathrm{~mL}$ de solução eletrolítica foi previamente aquecido com o auxílio de uma placa aquecedora, com agitação magnética, antes da célula ser fechada. Esse tratamento foi necessário para evitar a formação do íon permanganato na solução, que ocorria quando a mesma ficava em contato com o anodo de chumbo até que fosse atingida a temperatura necessária para se iniciar a eletrólise. É provável que a formação do íon permanganato se dê através da reação que pode ser representada pela equação. ${ }^{\text {(72) }}$

$$
5 \mathrm{PbO}_{2}+2 \mathrm{Mn}^{2+}+4 \mathrm{H}^{+} \rightarrow 2 \mathrm{MnO}_{4}^{-}+5 \mathrm{~Pb}^{2+}+2 \mathrm{H}_{2} \mathrm{O}
$$

Esse fenômeno foi verificado devido à mudança de coloração da solução eletrolítica durante o aquecimento, conforme pode ser observado na Figura 11. 


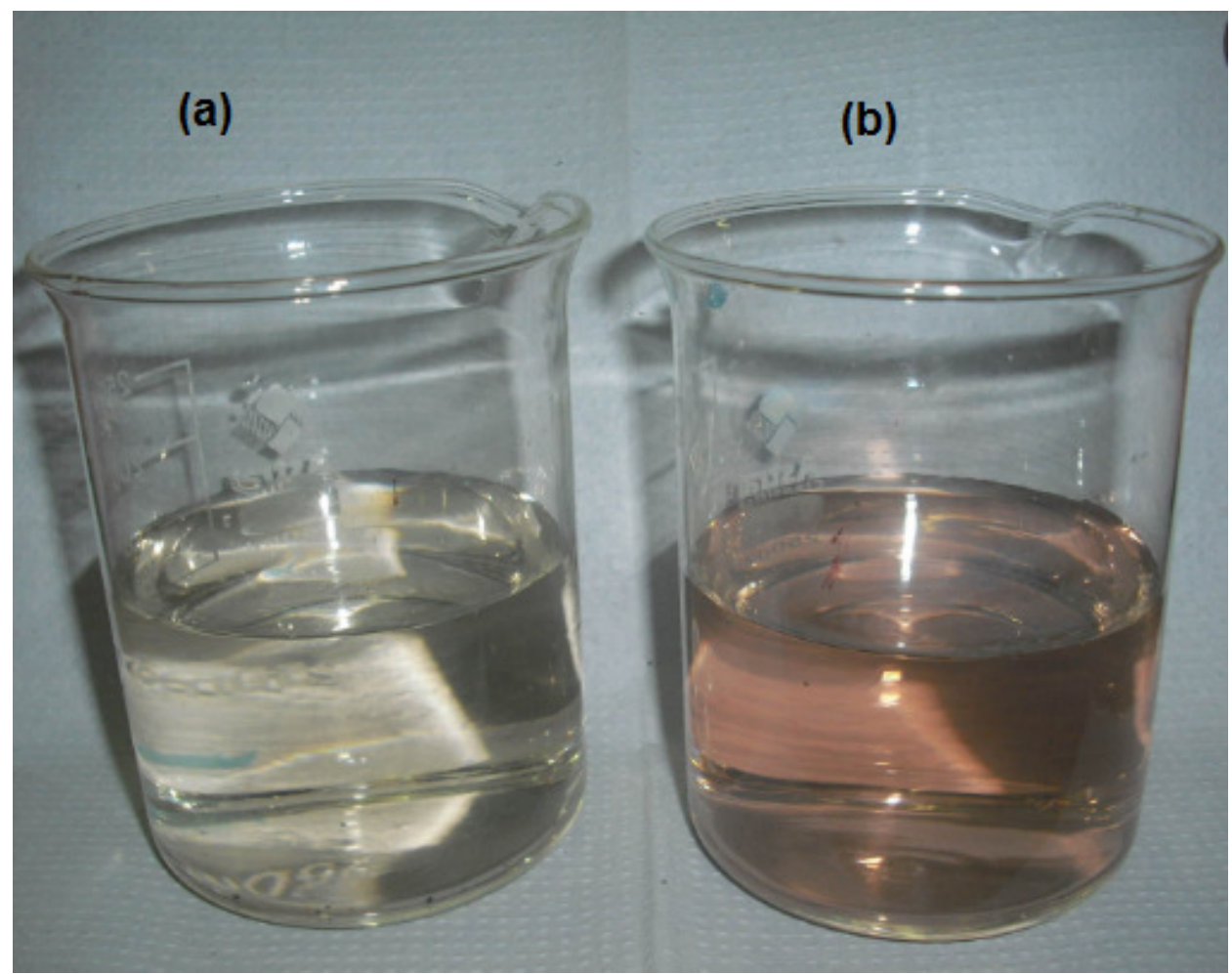

Figura 11 - Foto da mudança de coloração da solução eletrolítica durante o aquecimento a)Solução eletrolítica antes do aquecimento b) solução eletrolítica após o aquecimento.

O anodo foi previamente pesado numa balança analítica e parcialmente imerso $(3 \mathrm{~cm})$ no eletrólito já aquecido. Após o fechamento da célula, a síntese do DME foi realizada galvanostaticamente. Utilizou-se uma fonte de alimentação DC Regulada Power Supply modelo 3003 para monitorar a tensão e a corrente. A solução foi eletrolisada por 1 hora e 10 minutos à temperatura de $98^{\circ} \mathrm{C}\left( \pm 2^{0} \mathrm{C}\right)$ e à densidade de corrente de 1,69 A.dm ${ }^{-2}$.

Após esse período, o eletrodo de trabalho foi removido do banho eletrolítico e lavado com água destilada até atingir pH neutro. Em seguida, foi seco em estufa à temperatura de $100^{\circ} \mathrm{C}$ até atingir peso constante. $\mathrm{O}$ material depositado foi removido mecanicamente e enviado para caracterização.

Um dos parâmetros analisados durante a eletrólise foi a eficiência de corrente anódica, que representa a efetiva utilização da corrente durante o processo. 


\subsubsection{Efeito da Densidade de Corrente}

Nessa etapa a solução foi preparada com os mesmos reagentes e na mesma concentração da anterior. Porém, a água usada no preparo foi substituída por água deionizada e purificada (MILI-Q), com o objetivo de se evitarem possíveis contaminações provenientes da água destilada.

Utilizando-se o mesmo aparato descrito no item 3.2.1, cinco porções de $150 \mathrm{~mL}$ da solução eletrolítica com pH 0,30 foram anodicamente eletrolisadas por 4horas, à temperatura de $98^{\circ} \mathrm{C}\left( \pm 2^{\circ} \mathrm{C}\right)$. Para cada porção, determinou-se uma densidade de corrente diferente, que variou de 0,61 a 2,51A.dm ${ }^{-2}$.

Após cada processo de eletrólise, o anodo foi removido do banho eletrolítico e lavado com água $\mathrm{MILI}-\mathrm{Q}$, até apresentar $\mathrm{pH}$ neutro, e levado à estufa a $100^{\circ} \mathrm{C}$, até peso constante. Em seguida, a película de DME formada foi removida mecanicamente e lavada com água MILI-Q e com solução de hidróxido de amônio até apresentar $\mathrm{pH}$ entre 6 e 7 . Posteriormente, o DME foi levado à estufa a $100^{\circ} \mathrm{C}$, até apresentar peso constante. O material foi, em seguida, enviado para caracterização. A Tabela 12 mostra os ensaios realizados e as respectivas densidades de corrente.

Tabela 12- Ensaios e parâmetros empregados nos ensaios de eletrólise realizados a diferentes densidades de corrente.

\begin{tabular}{|c|c|c|c|}
\hline Ensaios & $J\left(A \cdot d m^{-2}\right)$ & Temp. $\left({ }^{\circ} \mathrm{C}\right)$ & Tempo(h) \\
\hline DMEJ 0,61 & 0,61 & \multirow{5}{*}{98} & \multirow{5}{*}{4} \\
\hline DMEJ 1,02 & 1,02 & & \\
\hline DMEJ 1,39 & 1,39 & & \\
\hline DMEJ 1,93 & 1,93 & & \\
\hline DMEJ 2,51 & 2,51 & & \\
\hline
\end{tabular}

\subsubsection{Efeito da concentração do Ácido Sulfúrico}

Para analisar os efeitos da concentração do ácido sulfúrico na deposição do $\mathrm{DME}$, foram preparadas cinco porções de $150 \mathrm{~mL}$ do eletrólito, com diferentes concentrações de ácido. A concentração em mo/L do ácido variou, entre as porções, 


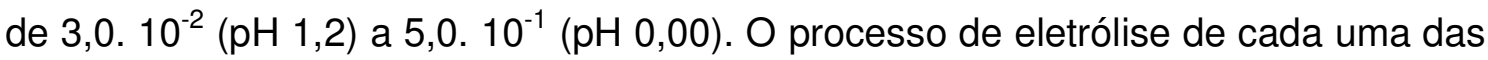
porções durou 7 horas, à temperatura de $98^{\circ} \mathrm{C}\left( \pm 2^{0} \mathrm{C}\right)$ e densidade de corrente de 1,15 A.dm ${ }^{-2}$. Esses parâmetros foram assim definidos, pois os melhores valores de eficiência de corrente (90-95\%) são alcançados quando a eletrodeposição ocorre em densidade de corrente a cerca de $1 \mathrm{~A} \cdot \mathrm{dm}^{-2}$, temperatura entre $90-90^{\circ} \mathrm{C}$ e em soluções de concentrações de ácido sulfúrico variando de 0,2 a 0,5 mol/L ${ }^{(14,55,63)}$.

Após a eletrólise, o anodo foi removido da solução e lavado com água MILIQ, até apresentar $\mathrm{pH}$ neutro, e levado à estufa a $100^{\circ} \mathrm{C}$, até apresentar peso constante. Em seguida o material foi removido mecanicamente, lavado com água MILIQ e com solução de hidróxido de amônio até apresentar pH entre 6 e 7. Foi novamente levado à estufa, a $100^{\circ} \mathrm{C}$, até apresentar peso constante. Em seguida, o material foi enviado para caracterização. A Tabela 13 contém o resumo dos ensaios realizados.

Tabela 13 - Ensaios e parâmetros empregados nos ensaios de eletrólise realizados a diferentes pH

\begin{tabular}{|c|c|c|c|c|}
\hline Ensaios & {$\left[\mathrm{H}_{2} \mathrm{SO}_{4}\right](\mathrm{mol} / \mathrm{L})$} & $\mathrm{pH}$ & Temp. $\left({ }^{\circ} \mathrm{C}\right)$ & Tempo(h) \\
\hline DMEpH 0,00 & $5,0.10^{-1}$ & 0,00 & \multirow{5}{*}{98} & \multirow{5}{*}{7} \\
\hline DMEpH 0,25 & $2,8 \cdot 10^{-1}$ & 0,25 & & \\
\hline DMEpH 0,50 & $1,6 \cdot 10^{-1}$ & 0,50 & & \\
\hline DMEpH 0,75 & $9,0 \cdot 10^{-2}$ & 0,75 & & \\
\hline DMEpH 1.20 & $3.0 \cdot 10^{-2}$ & 1.20 & & \\
\hline
\end{tabular}

\subsection{CARACTERIZAÇÃO}

O processo de caracterização dos depósitos de DME recolhidos dos anodos nas eletrólises realizadas tem por objetivo identificar as características do produto formado.

As técnicas utilizadas foram: espectrometria de fluorescência de raios- $X$, difração de raios- $X$, área superficial específica pelo método BET e microscopia eletrônica de varredura (MEV).

$\mathrm{Na}$ caracterização do DME preliminar, por se tratar de um resultado de experimento que objetivava especificamente a verificação da possibilidade de aplicação do método, foram aplicadas apenas as técnicas espectrometria de fluorescência de raios- $X$ e difração de raios- $X$. 
$\mathrm{Na}$ caracterização das amostras de DME obtidas a partir de variações de densidade de corrente e de concentração de ácido sulfúrico, foram empregadas todas as técnicas referenciadas anteriormente.

\subsubsection{Espectrometria de Fluorescência de Raios-X}

A técnica de espectrometria de fluorescência de raios- $X$ foi utilizada para a determinação qualitativa e quantitativa da presença de elementos nas amostras de DME. O equipamento utilizado foi um Espectrômetro de fluorescência de raios- $X$ seqüencial Axios Advanced (PANalytical). Antes das análises as amostras foram trituradas e seus pós prensados para preparação de pastilhas.

\subsubsection{Difração de raios-X}

A caracterização estrutural dos depósitos de DME foi realizada por difratometria de raios-X. O equipamento utilizado foi um difratômetro marca PHILIPS, modelo MPD 1880, com radiação incidente Cu-Ka. Antes da análise, as amostras de DME foram trituradas em um almofariz até se obter um pó suficientemente fino para os ensaios de difração.

As amostras de DME foram analisadas por difração de raios- $X$ para identificação de fases. O difratograma obtido foi comparado com difratogramas padrões das fichas cristalográficas do Joint Committee on Powder Diffraction Standards (JCPDS). 


\subsection{3 Área superficial específica BET}

A área superficial específica das diferentes amostras de DME foi determinada pelo método Brunauer, Emmett e Teller (BET). Foi utilizado para o preparo das amostras o aparelho Vac Prep 061 Micromeritics e para a determinação das áreas superficiais específicas o aparelho Gemini Micromeritics, no qual se empregou o gás nitrogênio. Antes das análises, as amostras permaneceram sob vácuo a frio por 3h e sob vácuo a $250^{\circ} \mathrm{C}$ por 15 horas, para se remover a água superficial. O tamanho médio das partículas foi calculado pela equação. ${ }^{(73)}$

$$
D_{E E T}=\frac{6}{\rho_{\mathrm{t}} \mathrm{S}_{\mathrm{B}, \mathbb{E}, T}}
$$

Onde $D_{\mathrm{BET}}$ é o diâmetro esférico equivalente à partícula; $\rho_{\mathrm{t}}$ é a densidade teórica obtida a partir da ficha cristalográfica JCPDS 30-0820, referente à forma alotrópica $\varepsilon-\mathrm{MnO}_{2}\left(4,83 \mathrm{~g} \cdot \mathrm{cm}^{-3}\right)$ e $\mathrm{S}_{\mathrm{BET}}$ é a área superficial obtida pelo método BET.

\subsubsection{Microscopia Eletrônica de Varredura (MEV)}

A caracterização morfológica dos depósitos de DME foi realizada por microscopia eletrônica de varredura (MEV), usando-se um microscópio marca PHILIPS, modelo XL-30, combinado a um sistema de análise elementar semiquantitativo da dispersão de energia de raios-X (EDS). 


\section{RESULTADOS E DISCUSSÃO}

\subsection{ENSAIO PRELIMINAR PARA OBTENÇÃO DO DIÓXIDO DE MANGANÊS ELETROLÍTICO}

No ensaio preliminar de eletrólise para obtenção do DME, verificou-se evolução de gás no contra eletrodo (catodo) e formação de um sólido de coloração preta no eletrodo de trabalho (anodo).

Assim, com o objetivo de se verificarem as possibilidades de formação de produtos a partir do processo eletrolítico da solução estudada, procedeu-se a análise teórica de tabela de potenciais dos íons presentes nela.

A Tabela 14 apresenta resultados para temperatura de $25^{\circ} \mathrm{C}$ e, através dela se pode prever, teoricamente, as reações possíveis de ocorrer em cada eletrodo.

Tabela 14 - Potenciais Padrões de Redução a 25ํ․ . $^{(6)}$

\begin{tabular}{|c|c|}
\hline 드 (Volts) & Reações \\
\hline$\overline{1,23}$ & $\mathrm{MnO}_{2(\mathrm{~s})}+4 \mathrm{H}^{+}{ }_{(\mathrm{aq})}+2 \mathrm{e}^{-} \leftrightharpoons \mathrm{Mn}^{2+}{ }_{(\mathrm{aq})}+2 \mathrm{H}_{2} \mathrm{O}$ \\
\hline 1,82 & $\mathrm{Co}^{3+}{ }_{(\mathrm{aq})}+\mathrm{e}^{-} \leftrightharpoons \mathrm{Co}^{2+}{ }_{(\mathrm{aq} .)}$ \\
\hline 0,00 & $2 \mathrm{H}^{+}{ }_{\text {(aq.) }}+2 \mathrm{e}^{-} \rightarrow \mathrm{H}_{2(\mathrm{~g})}$ \\
\hline$-1,03$ & $\mathrm{Mn}^{2+}($ aq. $)+2 \mathrm{e}^{-} \leftrightharpoons \mathrm{Mn}_{(\mathrm{s})}$ \\
\hline$-0,25$ & $\mathrm{Ni}^{2+}{ }_{(\text {aq. })}+2 \mathrm{e}^{-} \leftrightharpoons \mathrm{Ni}_{(\mathrm{s})}$ \\
\hline$-0,28$ & $\mathrm{Co}^{2+}(\mathrm{aq})+.2 \mathrm{e}^{-} \leftrightharpoons \mathrm{Co}_{(\mathrm{s})}$ \\
\hline$-2,76$ & $\mathrm{Ca}^{2+}{ }_{(\mathrm{aq} .)}+2 \mathrm{e}^{-} \leftrightharpoons \mathrm{Ca}_{(\mathrm{s})}$ \\
\hline$-0,13$ & $\mathrm{~Pb}^{2+}($ aq. $)+2 \mathrm{e}^{-} \leftrightharpoons \mathrm{Pb}_{(\mathrm{s})}$ \\
\hline
\end{tabular}

\section{Reações Catódicas (Redução)}

$$
\begin{aligned}
& 2 \mathrm{H}^{+}{ }_{(\text {aq. })}+2 \mathrm{e}^{-} \rightarrow \mathrm{H}_{2(\mathrm{~g})} \varepsilon=0,00 \mathrm{~V} \\
& \mathrm{Mn}^{2+}{ }_{(\text {aq. })}+2 \mathrm{e} \rightarrow \mathrm{Mn}^{0}{ }_{(\mathrm{s})} \varepsilon=-1,03 \mathrm{~V} \\
& \mathrm{Co}^{2+}{ }_{(\text {aq. })}+2 \mathrm{e}^{-} \rightarrow \mathrm{Co}_{(\mathrm{s})} \varepsilon=-0,28 \mathrm{~V} \\
& \mathrm{Ni}^{2+}{ }_{(\text {aq. })}+2 \mathrm{e}^{-} \rightarrow \mathrm{Ni}_{(\mathrm{s})} \varepsilon=-0,25 \mathrm{~V}
\end{aligned}
$$


$\mathrm{Ca}^{2+}{ }_{(\text {aq. })}+2 \mathrm{e}^{-} \rightarrow \mathrm{Ca}_{(\mathrm{s})} \varepsilon=--2,76 \mathrm{~V}$

$\mathrm{Pb}^{2+}{ }_{(\text {aq. })}+2 \mathrm{e}^{-} \rightarrow \mathrm{Pb}_{(\mathrm{s})} \varepsilon=-0,13 \mathrm{~V}$

O íon hidrogênio possui maior potencial de redução que os íons: manganês, cobalto, níquel, cálcio e chumbo. Portanto, conclui-se que a reação catódica é a redução do cátion hidrogênio em gás hidrogênio.

Reação Catódica: $2 \mathrm{H}^{+}{ }_{(\text {aq. })}+2 \mathrm{e}^{-} \rightarrow \mathrm{H}_{2(\mathrm{~g})} \uparrow$

\section{Reações Anódicas}

$\mathrm{Mn}^{2+}{ }_{(\mathrm{aq})}+2 \mathrm{H}_{2} \mathrm{O} \rightarrow \mathrm{MnO}_{2(\mathrm{~s})}+4 \mathrm{H}^{+}+2 \mathrm{e}^{-} \varepsilon=-1,23 \mathrm{~V}$

$\mathrm{SO}_{4}{ }^{2-}$ (aq.) $\rightarrow \mathrm{S}_{2} \mathrm{O}_{8}{ }^{2-}{ }_{\text {(aq.) }}+2 \mathrm{e}^{-} \varepsilon=-2,00 \mathrm{~V}$

$\mathrm{Co}^{2+}{ }_{(\text {aq. })} \rightarrow \mathrm{Co}^{3+}{ }_{(\mathrm{aq})}+\mathrm{e}^{-} \varepsilon=-1,82$

O potencial de oxidação do íon manganês é maior que os dos íons: $\mathrm{Mn}^{2+}$, $\mathrm{Co}^{2+} \mathrm{e} \mathrm{SO}_{4}{ }^{2-}$ presentes na solução eletrolítica. Portanto, a reação possível de ocorrer no eletrodo de trabalho é a oxidação do íon manganês.

Reação anódica: $\mathrm{Mn}^{2+}{ }_{(\mathrm{aq})}+2 \mathrm{H}_{2} \mathrm{O} \rightarrow \mathrm{MnO}_{2(\mathrm{~s})}+4 \mathrm{H}^{+}+2 \mathrm{e} \varepsilon=-1,23 \mathrm{~V}$

Vale ressaltar que, nos procedimentos experimentais executados para este trabalho, embora se tenha utilizado temperatura superior à apresentada na tabela 16 , os resultados obtidos foram correspondentes, quando aplicada tensão também superior.

A reação geral do processo é representada pela seguinte equação:

Reação geral do processo: $\mathrm{Mn}^{2+}{ }_{(\text {aq. })}+2 \mathrm{H}_{2} \mathrm{O}_{(\mathrm{l})} \rightarrow \mathrm{MnO}_{2(\mathrm{~s}) \downarrow}+2 \mathrm{H}^{+}{ }_{(\text {aq. })}+\mathrm{H}_{2(\mathrm{~g})}{ }^{\uparrow}$.

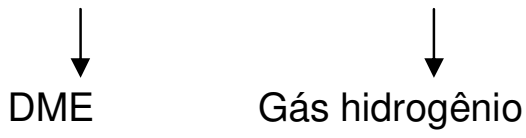

(Anodo) (Catodo) 
É interessante observar que a presença das impurezas metálicas $\mathrm{Ca}(270 \mathrm{mg} / \mathrm{L}), \mathrm{Pb}(20 \mathrm{mg} / \mathrm{L}), \mathrm{Ti}(400 \mathrm{mg} / \mathrm{L})$, Co(630mg/L) e Ni $(3.000 \mathrm{mg} / \mathrm{L})$ contidas no banho eletrolítico não impediu a deposição do $\mathrm{MnO}_{2}$.

A eficiência de corrente (E.C) da oxidação eletrolítica foi de $116 \%$. Esse valor foi calculado usando-se a seguinte equação, deduzida a partir da lei de Faraday:

$$
E \cdot C(\%)=\frac{M n F}{W t} \times 100 \quad, \text { onde }
$$

$M=$ massa real depositada sobre o eletrodo

$\mathrm{n}$ = número de elétrons envolvidos na reação

$\mathrm{F}=$ Constante de Faraday (96500 C)

I = Corrente em Amperes

$\mathrm{t}=$ tempo em segundos

$\mathrm{W}=$ massa molar do $\mathrm{MnO}_{2}$

Valores acima de $100 \%$ para a eficiência de corrente no processo de obtenção do DME já foram registrados na literatura $(14,60,74)$ No entanto, deve-se considerar que a presença de água estrutural, presença de contaminantes ou a deposição de eletrólitos nos poros do material, que é tipicamente poroso, podem mascarar o resultado por gerar aumento de massa total do depósito. ${ }^{(20)}$

\subsubsection{Aspecto físico}

A película de dióxido de manganês formado sobre o eletrodo se desprende na forma de placas finas e irregulares. O DME tem uma tendência a formar finas fissuras quando é extraído de um banho eletrolítico quente e arrefecido a temperatura ambiente. Consequentemente, o produto final apresenta-se muitas vezes quebrado em pedaços irregulares. ${ }^{(59,63)}$ A Figura 12 apresenta imagem das partículas do DME. 


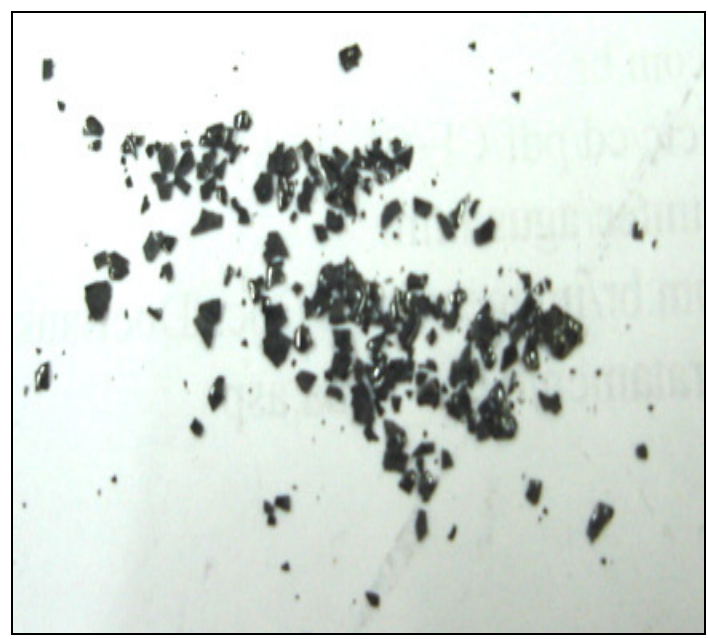

Figura 12 - Foto do DME produzido nas condições $\mathrm{j}=1,69 \mathrm{~A} \cdot \mathrm{dm}^{-2}$ e $\mathrm{T}=98^{\circ} \mathrm{C}$ após removido da superfície do eletrodo.

\subsubsection{Análise química}

A Tabela 15 apresenta a composição química do material depositado sobre 0 eletrodo de chumbo e a composição do DME comercial. ${ }^{(49,75)}$

Tabela 15- Resultado da análise química por espectrometria de fluorescência de raios- $X$ do DME obtido para $1,69 \mathrm{~A} \cdot \mathrm{dm}^{-2}$ e $98^{\circ} \mathrm{C}\left( \pm 2^{\circ} \mathrm{C}\right)$ e a composição do DME comercial (dados em porcentagem em massa).

\begin{tabular}{cccc}
\hline \multicolumn{2}{c}{ Amostra DME preliminar } & \multicolumn{2}{c}{ Amostra DME comercial } \\
\hline Composição & Concentração & \multicolumn{1}{c}{ Composição } & Concentração \\
\hline $\mathrm{MnO}_{2}$ & 93,89 & $\mathrm{MnO}_{2}$ & 91 (mínima) \\
\hline $\mathrm{Co}$ & 0,19 & $\mathrm{Co}$ & $0,0005-0,003$ \\
\hline $\mathrm{Ni}$ & 0,21 & $\mathrm{Ni}$ & $0,0005-0,003$ \\
\hline $\mathrm{Pb}$ & 1,34 & $\mathrm{~Pb}$ & 0,2 (no máximo) \\
\hline $\mathrm{Ti}$ & 1,39 & $\mathrm{Ti}$ & 0,025 \\
\hline $\mathrm{Ca}$ & 0,04 & $\mathrm{Cu}$ & 0,0005 \\
\hline $\mathrm{Na}$ & 0,37 & $\mathrm{Na}$ & 0,23 \\
\hline $\mathrm{P}$ & 0,02 & $\mathrm{NH}_{4}{ }^{+}$ & 0,02 \\
\hline $\mathrm{S}$ & 1,50 & $\mathrm{SO}_{4}{ }^{2-}$ & 1,3 \\
\hline $\mathrm{Cl}$ & $\mathrm{HCl}$ & 0,10 \\
\hline $\mathrm{K}$ & 0,25 & $\mathrm{~K}$ & 0,03 \\
\hline $\mathrm{Fe}$ & 0,47 & $\mathrm{Fe}$ & $<1$ \\
\hline $\mathrm{Al}$ & 0,21 & & \\
\hline $\mathrm{Si}$ & 0,03 & & \\
\hline
\end{tabular}


Analisando os resultados, nota-se que o teor de pureza do dióxido de manganês obtido nas condições do experimento foi de 93,89\%. Comparando os resultados das análises com as especificações do dióxido de manganês eletrolítico comercial percebe-se que, quanto à concentração de $\mathrm{MnO}_{2}$, o resultado está de acordo com a especificação requerida para o uso na produção de pilhas - $\mathrm{MnO}_{2}$ (seco) porcentagem mínima de 91\%.

Analisando as impurezas presentes no resultado da análise, percebe-se que houve contaminação tanto por materiais adicionados ao banho eletrolítico (o que é perfeitamente explicável) quanto por outros materiais. Essa contaminação pode ser proveniente de impurezas das substâncias químicas utilizadas para o banho, de contaminação externa de impurezas do material do eletrodo ou da manipulação da amostra. Além disso, o material foi analisado por FRX e portanto pode ser um erro causado pela técnica de análise.

Dentre as impurezas encontradas, comumente descritas na literatura : o teor de chumbo (1,34\%) está acima do valor permitido que é de, no máximo, $0,2 \% \mathrm{~A}$ concentração do $\mathrm{Pb}$ sugere a contaminação do DME durante a etapa de remoção do material depositado sobre o eletrodo de chumbo. Devido ao tamanho do eletrodo, área superficial de $0,3 \mathrm{dm}^{2}$, foi necessária a remoção quase que total do material depositado para se obter massa suficiente para efetuar a caracterização do DME. Possivelmente este tipo de contaminação seria minimizado se o processo fosse efetuado em uma escala maior. $\mathrm{Ni}$, Co e Ti, também se encontram acima dos valores exigidos para um DME grau bateria, uma vez que os valores especificados para o DME comercial ${ }^{(49,75,76)}$ para tais elementos são: 0,0005\% a 0,003\% para Ni e Co e $0,025 \%$ para $\mathrm{Ti}$.

\subsubsection{Difração de raios-X}

A caracterização estrutural do dióxido de manganês foi realizada por meio de difração de raios -X. A Figura 13 ilustra o difratograma de raios-X para amostra de DME produzido a $98^{\circ} \mathrm{C}\left( \pm 2^{\circ} \mathrm{C}\right)$ e densidade de corrente $1,69 \mathrm{~A} \cdot \mathrm{dm}^{-2}$.

Observam-se reflexões concordantes com a ficha cristalográfica JCPDS $30-0820$, referente à forma alotrópica $\varepsilon-\mathrm{MnO}_{2}$. Desse resultado, conclui-se que os 
parâmetros de eletrólise usados no experimento são favoráveis à formação de DME com predominância da forma $\varepsilon-\mathrm{MnO}_{2}$, desejável para a fabricação de pilhas. Por outro lado, o aspecto do difratograma obtido indica que a cristalinidade da amostra é baixa. A natureza pobremente cristalina é descrita na literatura. ${ }^{(15,57,74)}$

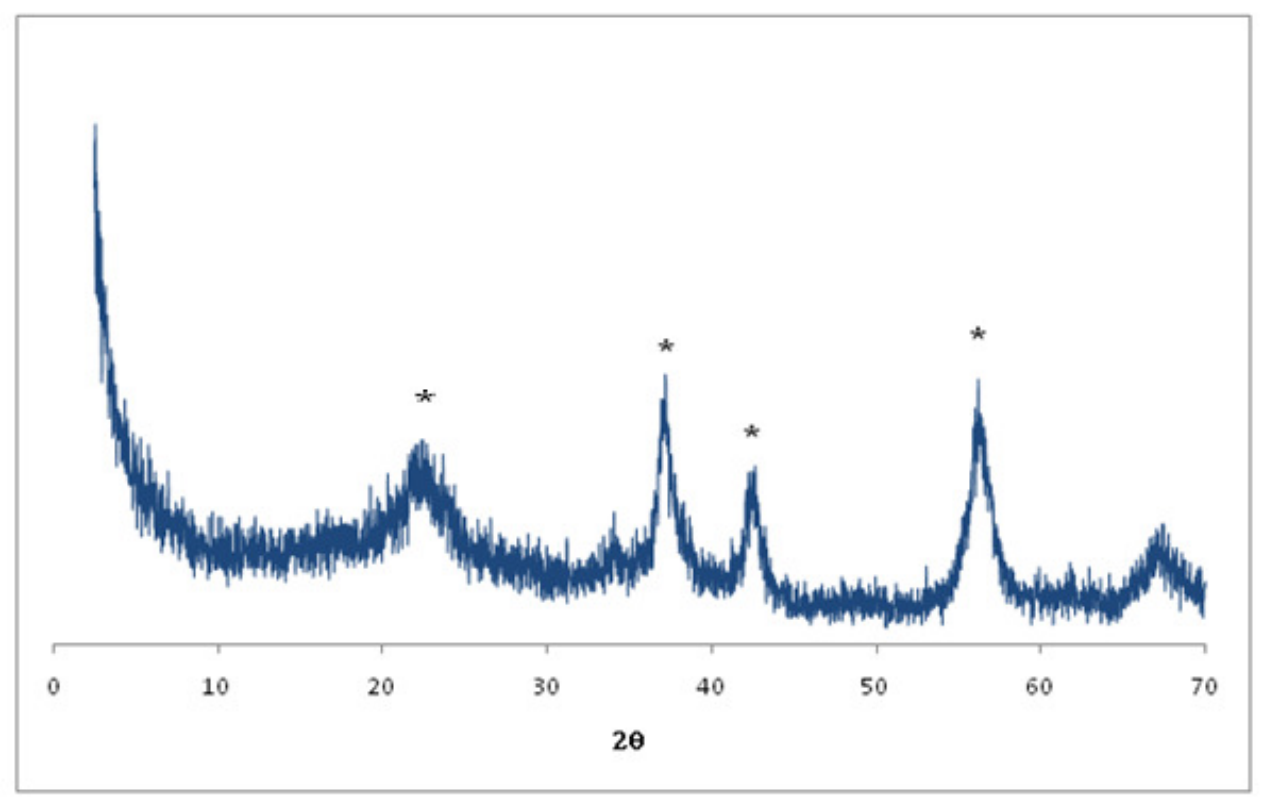

Figura 13- Difratograma de raios- $\mathrm{X}$ da amostra do DME (* Picos característicos do $\varepsilon-\mathrm{MnO}_{2}$ )

\subsection{EFEITO DA DENSIDADE DE CORRENTE}

\subsubsection{Eficiência de corrente}

O comportamento da eficiência de corrente anódica durante o processo eletrolítico foi analisado variando-se a densidade de corrente. Na Figura 14 é mostrada a eficiência de corrente anódica para ensaios realizados em diferentes densidades de corrente. 


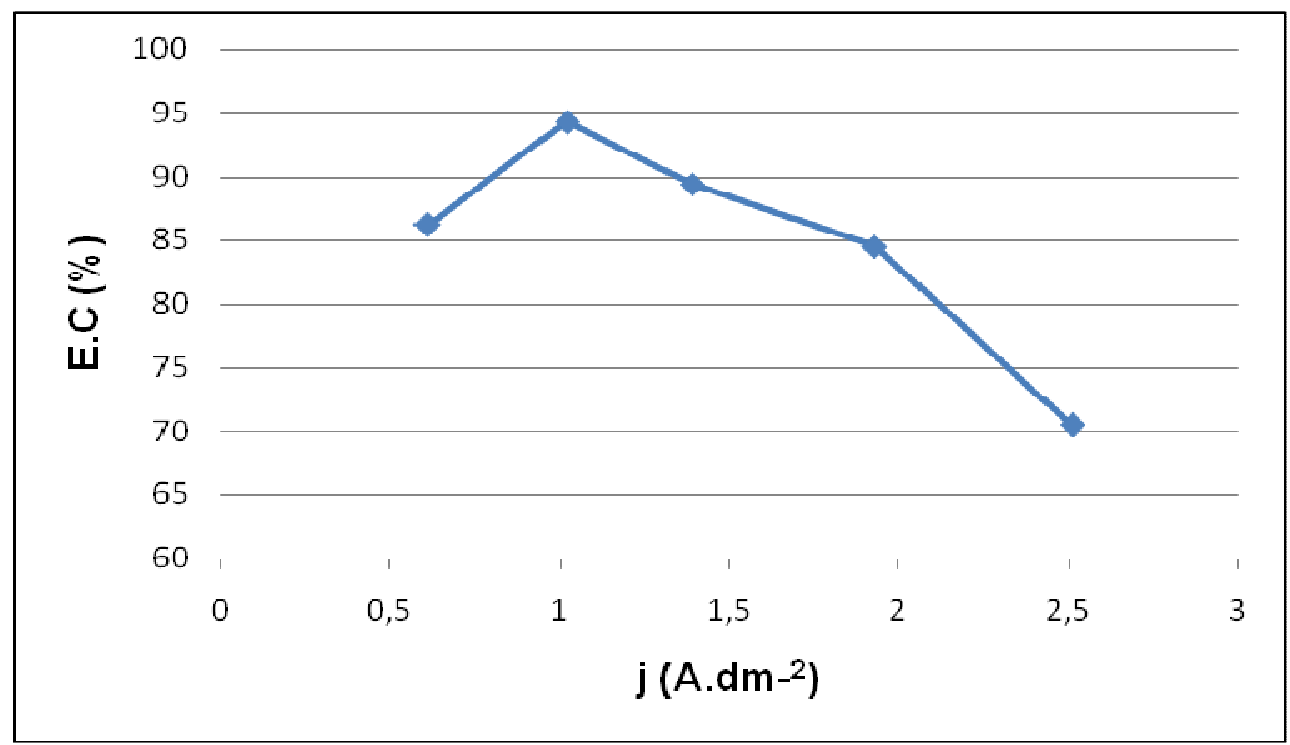

Figura 14 - Efeito da densidade de corrente na eficiência de corrente anódica nos ensaios de produção do DME.

Nota-se que a eficiência de corrente do processo de obtenção do dióxido de manganês inicialmente cresce com o aumento da densidade de corrente, passa por um máximo (94,3\%) e depois decresce. A eficiência máxima se verifica na densidade de corrente de 1,02A. $\mathrm{dm}^{-2}$, que é o valor adotado normalmente no processo de obtenção do DME. Observa-se um decréscimo acentuado da eficiência de corrente $(70,5 \%)$ com o aumento da densidade de corrente $\left(2,51 \mathrm{~A} \cdot \mathrm{dm}^{-2}\right)$. Essa variação da eficiência de corrente decorre do fato de que, em densidade de corrente elevada, a eletrólise da água é ativada e a evolução de oxigênio pode tornar-se uma reação competitiva para a deposição do dióxido de manganês, diminuindo a eficiência de corrente. ${ }^{(60)}$

Outro aspecto que pode ser considerado é o fato de que, em alta densidade de corrente, a taxa de eletrodeposição é maior do que o transporte de íons para o eletrodo e a concentração dos íons metálicos nas proximidades do anodo é reduzida. ${ }^{(60)}$

Esses resultados se aproximam dos valores encontrados por Ghaemi e Binder $^{(60)}$, que verificaram que maiores valores na eficiência de corrente (91 a 99\%) foram obtidos em densidade de corrente na faixa de $1 \mathrm{~A} \cdot \mathrm{dm}^{-2}$. Eficiência de corrente de $80 \%$ foi obtida entre 1,39-1,35 A.dm ${ }^{-2}$ e em densidade muito elevada, como por exemplo 3,75 A.dm ${ }^{-2}$ a eficiência de corrente decresceu para $36 \%$. 


\subsection{2 Área superficial específica}

Os valores de área superficial específica (ASE) determinados por BET, das amostras de DME produzidas a diferentes densidades de corrente são mostrados na Figura 15.

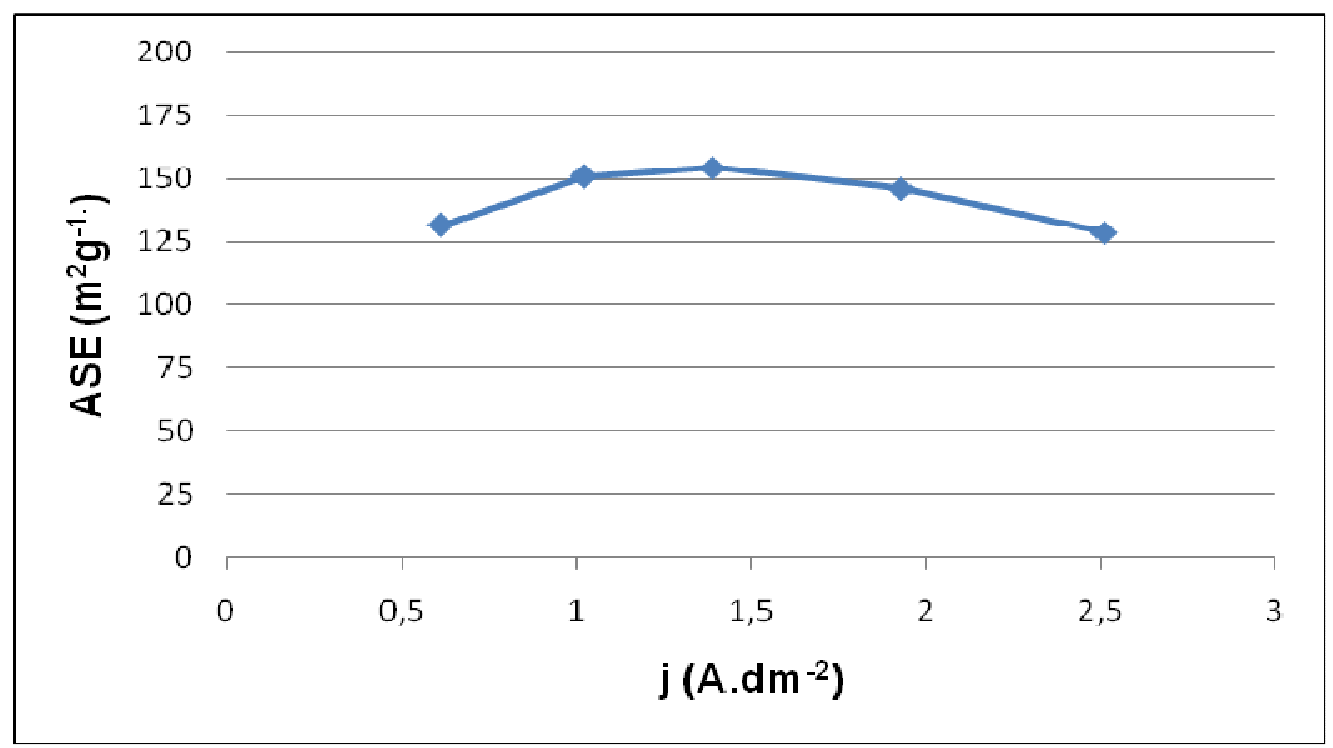

Figura 15- Efeito da densidade de corrente na área superficial do dióxido de manganês eletrolítico.

Verifica-se que a área superficial específica do DME tende a aumentar com a elevação da densidade de corrente de $0,61 \mathrm{~A} \cdot \mathrm{dm}^{-2}\left(131,5430 \mathrm{~m}^{2} \cdot \mathrm{g}^{-1}\right)$ para $1,02 \mathrm{~A} \mathrm{dm}^{-2}\left(150,8519 \mathrm{~m}^{2} \cdot \mathrm{g}^{-1}\right)$ e se mantém praticamente constante a partir deste ponto até a densidade de corrente $1,93 \mathrm{~A} \cdot \mathrm{dm}^{-2}\left(150,8519 \mathrm{~m}^{2} / \mathrm{g}, 154,4405 \mathrm{~m}^{2} / \mathrm{g} \mathrm{e}\right.$ $145,9510 \mathrm{~m}^{2} / \mathrm{g}$ ). Na densidade de corrente $2,51 \mathrm{~A} \cdot \mathrm{dm}^{-2}$ ao contrário do esperado ocorreu um acentuado decréscimo da área superficial específica (128,6967 A.dm ${ }^{-2}$ ) Este resultado pode ser proveniente da falta de um controle mais eficiente das variáveis do processo durante a execução do experimento para essa amostra.

Dutra $^{(14)}$ afirma que o aumento da densidade de corrente é o fator mais relevante no aumento da área superficial específica do dióxido de manganês, pois leva a formação de estruturas dendríticas no depósito. O autor encontrou os seguintes valores para área superficial do dióxido de manganês: $70,1 \mathrm{~m}^{2} / \mathrm{g}$ para densidade $0,4 \mathrm{~A} \cdot \mathrm{dm}^{-2}$ e $141,0 \mathrm{~m}^{2} / \mathrm{g}$, para densidade de corrente $0,8 \mathrm{~A} \cdot \mathrm{dm}^{-2}$ a $90^{\circ} \mathrm{C}$. 
Davis et $\mathrm{al}^{(77)}$ afirmam que o DME é um sólido denso com porosidade interna significativa, o que conduz a uma elevada área superficial BET $\left(20-100 \mathrm{~m}^{2} \mathrm{~g}^{-1}\right)$.

O aumento na área superficial específica com a densidade de corrente é, presumivelmente devido a uma alta taxa de nucleação com densidade de corrente elevada, que resulta em muitas pequenas partículas primárias $^{(78)}$

O tamanho das partículas do DME obtido nesta pesquisa se encontra ente 8 e $9 \mathrm{~nm}$. O aumento da área superficial específica se deve à diminuição no tamanho das partículas do DME formado. Os valores área superficial específica e tamanho médio das partículas das amostras de DME obtidas a diferentes densidades de corrente, determinados por BET, são mostrados na Tabela 16.

Tabela 16 - Área superficial específica e tamanho médio das partículas das amostras de DME obtidas a diferentes densidades de correntes.

\begin{tabular}{ccc}
\hline $\begin{array}{c}\text { Densidade de Corrente } \\
\left(\mathrm{A} . \mathrm{dm}^{-2}\right)\end{array}$ & $\begin{array}{c}\text { Área Superficial } \\
\left(\mathrm{m}^{2} \cdot \mathrm{g}^{-1}\right)\end{array}$ & $\begin{array}{c}\mathrm{D}_{\text {B.E.T }} \\
(\mathrm{nm})\end{array}$ \\
\hline 0,61 & 131,5430 & 9 \\
\hline 1,02 & 150,8519 & 8 \\
\hline 1,39 & 154,4405 & 8 \\
\hline 1,93 & 145,9510 & 8 \\
\hline 2,51 & 128,6967 & 9 \\
\hline
\end{tabular}

O aumento na área superficial do dióxido de manganês favorece o mecanismo de descarga de uma pilha, pois o processo de difusão é facilitado ${ }^{(79)}$ e favorece também o processo de obtenção do espinélio, devido à possibilidade de maiores níveis de inserção dos íons lítio na sua estrutura ${ }^{(73)}$.

\subsubsection{Análise química}

A composição química das amostras de DME produzidas em distintas densidades de corrente é mostrada na Tabela 17. 
Tabela 17- Resultados das análises químicas por espectrometria de fluorescência de raios- $X$ das amostras de DME obtidas em diferentes densidades de corrente (dados em porcentagem em massa).

\begin{tabular}{cccccc}
\hline Composição & $\mathrm{J}=0,61 \mathrm{~A} \cdot \mathrm{dm}^{-2}$ & $\mathrm{~J}=1,02 \mathrm{~A} \cdot \mathrm{dm}^{-2}$ & $\mathrm{~J}=1,39 \mathrm{~A} \cdot \mathrm{dm}^{-2}$ & $\mathrm{~J}=1,93 \mathrm{~A} \cdot \mathrm{dm}^{-2}$ & $\mathrm{~J}=2,51 \mathrm{~A} \cdot \mathrm{dm}^{-2}$ \\
\hline $\mathrm{F}$ & 1,89 & 1,73 & 1,73 & $\mathrm{nd}$ & 1,38 \\
\hline $\mathrm{Na}$ & $\mathrm{nd}$ & $\mathrm{nd}$ & $\mathrm{nd}$ & $\mathrm{nd}$ & $\mathrm{nd}$ \\
\hline $\mathrm{Al}$ & $\mathrm{nd}$ & 0,01 & 0,01 & 0,01 & 0,01 \\
\hline $\mathrm{Si}$ & 0,01 & 0,03 & 0,07 & 0,02 & 0,03 \\
\hline $\mathrm{P}$ & $<<$ & $<<$ & $<<$ & $<<$ & 0,01 \\
\hline $\mathrm{S}$ & 1,33 & 0,64 & 0,78 & 0,94 & 0,57 \\
\hline $\mathrm{K}$ & 0,14 & 0,15 & 0,18 & 0,22 & 0,20 \\
\hline $\mathrm{Ca}$ & 0,01 & 0,01 & $\mathrm{nd}$ & 0,01 & $\mathrm{nd}$ \\
\hline $\mathrm{Ti}$ & 0,67 & 0,63 & 0,52 & 0,52 & 0,84 \\
\hline $\mathrm{MnO} \mathrm{C}_{2}$ & 94,98 & 95,44 & 95,83 & 97,35 & 96,00 \\
\hline $\mathrm{Fe}$ & 0,13 & 0,16 & 0,12 & 0,13 & 0,14 \\
\hline $\mathrm{Co}$ & 0,20 & 0,15 & 0,08 & 0,14 & 0,11 \\
\hline $\mathrm{Ni}$ & 0,14 & 0,09 & 0,12 & 0,10 & 0,09 \\
\hline $\mathrm{Zn}$ & $\mathrm{nd}$ & $\mathrm{nd}$ & $\mathrm{nd}$ & 0,02 & $\mathrm{nd}$ \\
\hline $\mathrm{Pb}$ & 0,50 & 0,96 & 0,56 & 0,54 & 0,62 \\
\hline
\end{tabular}

A faixa utilizada para variação na densidade de corrente $\left(0,61\right.$ a 2,51 A.dm $\left.{ }^{-2}\right)$ não afetou significativamente o teor de $\mathrm{MnO}_{2}$ presente nos produtos finais, que apresentaram teores acima de $90 \%$.

A Figura 16 mostra o efeito da densidade de corrente sobre a contaminação do DME pelos íons metálicos dissolvidos na solução eletrolítica

Com relação às impureza metálicas presentes no banho eletrolítico $(\mathrm{Ca}, \mathrm{Ti}$, $\mathrm{Co}, \mathrm{Ni}$ e $\mathrm{Pb}$ ), verifica-se que a contaminação do $\mathrm{Ca}$ no produto final é mínima para as diferentes densidades de corrente utilizadas. Os menores teores de contaminação de Ti e Co ocorrem à densidade de corrente de 1,39 A.dm ${ }^{-2}$. Para os metais $\mathrm{Ni}$ e $\mathrm{Pb}$, a densidade de corrente que favorece sua menor contaminação no DME é $1,02 \mathrm{~A} \cdot \mathrm{dm}^{-2}$ e 1,93 A.dm ${ }^{-2}$ respectivamente. 


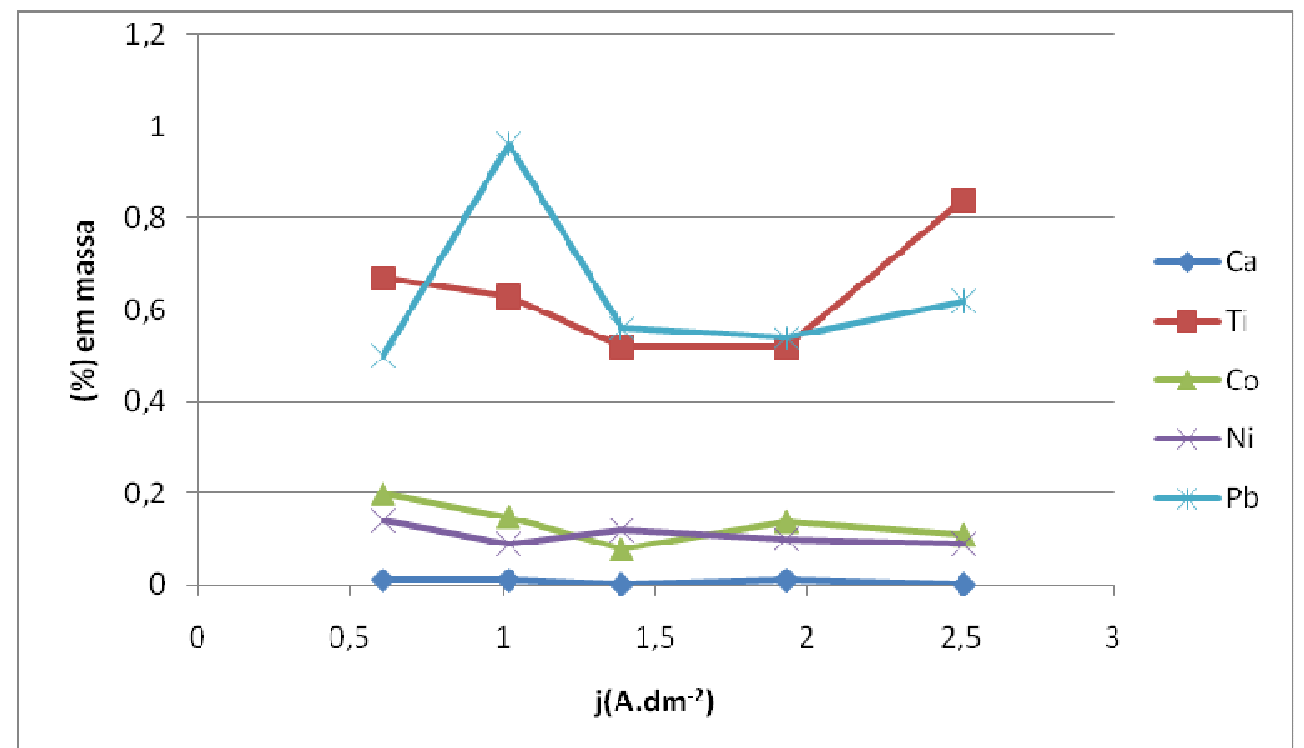

Figura 16 - Efeito da densidade de corrente anódica na incorporação dos íons metálicos $\mathrm{Ca}, \mathrm{Ti}, \mathrm{Co}$, $\mathrm{Ni}$ e $\mathrm{Pb}$ nas amostras de DME.

O intervalo de densidade de corrente em que ocorre menor contaminação desses metais situa-se acima de $1,0 \mathrm{Adm}^{-2}$ e abaixo de 2,0 $\mathrm{Adm}^{-2}$.

\subsubsection{Difração de raios-X}

A Figura 17 ( $a, b$ e c) mostra os difratogramas do pó dos DME obtidos nas densidades de corrente $0,61 \mathrm{~A} \cdot \mathrm{dm}^{-2}, 1,02 \mathrm{~A} \cdot \mathrm{dm}^{-2}$ e 1,39 A.dm ${ }^{-2}$, no período de $4 \mathrm{~h}$, a temperatura de $98^{\circ} \mathrm{C}$. A Figura 18 ( $\mathrm{a}$ e b) mostra os difratogramas para as amostras obtidas nas densidades de corrente $1,93 \mathrm{~A} \cdot \mathrm{dm}^{-2}$ e $2,51 \mathrm{~A} \cdot \mathrm{dm}^{-2}$ no período de $4 \mathrm{~h}$, a temperatura de $98^{\circ} \mathrm{C}$. 

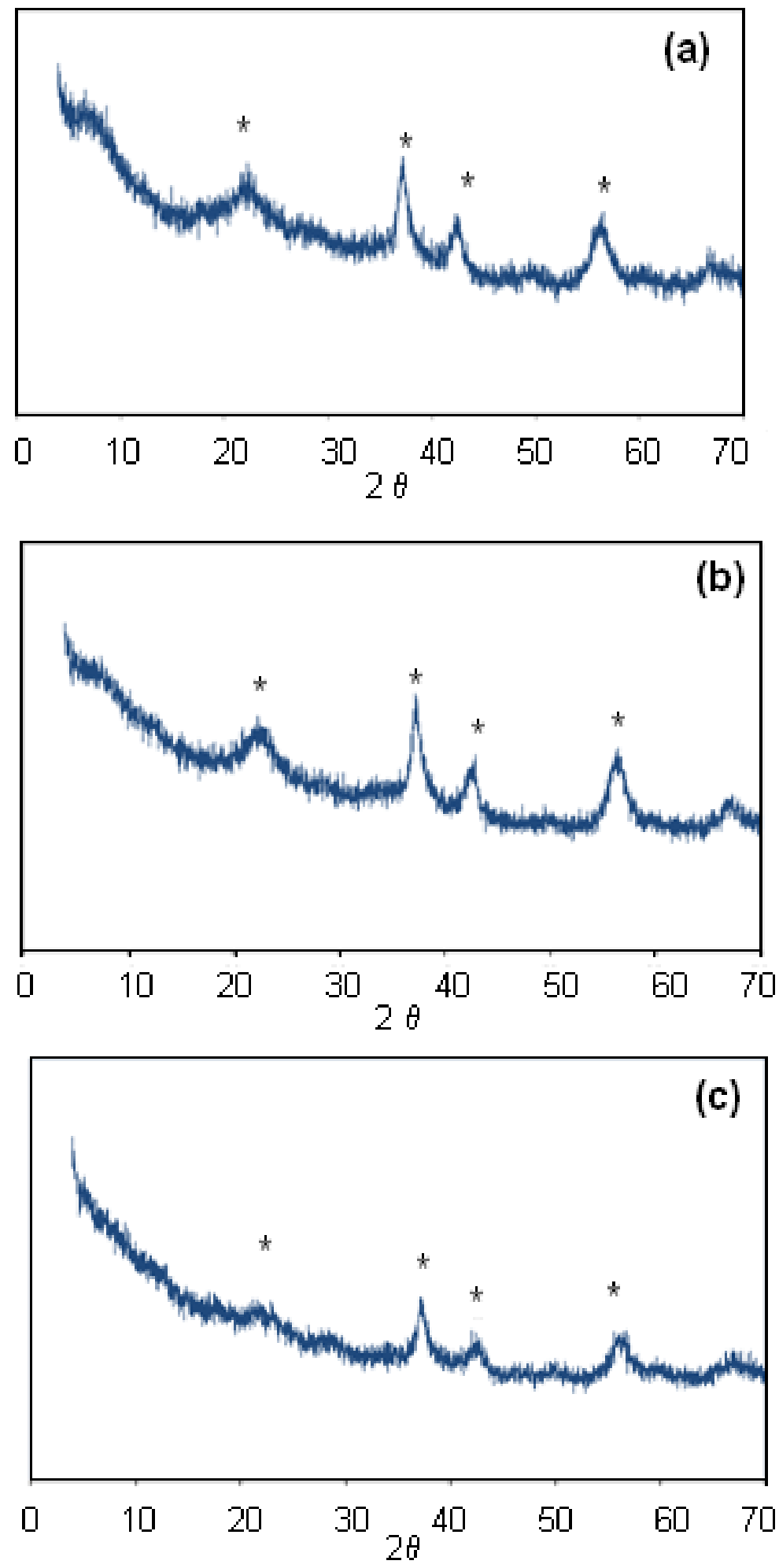

Figura 17 - Difratogramas de raios-X das amostras de DME: a) 0,61 A.dm ${ }^{-2}$; b) $1,02{\mathrm{~A} . \mathrm{dm}^{-2}}^{-2}$ c) $1,39 \mathrm{~A} \cdot \mathrm{dm}^{-2}$ obtidos a $98^{\circ} \mathrm{C}$ por $4 \mathrm{~h}$. ("Picos característicos do $\left.\varepsilon-\mathrm{MnO}_{2}\right)$ 

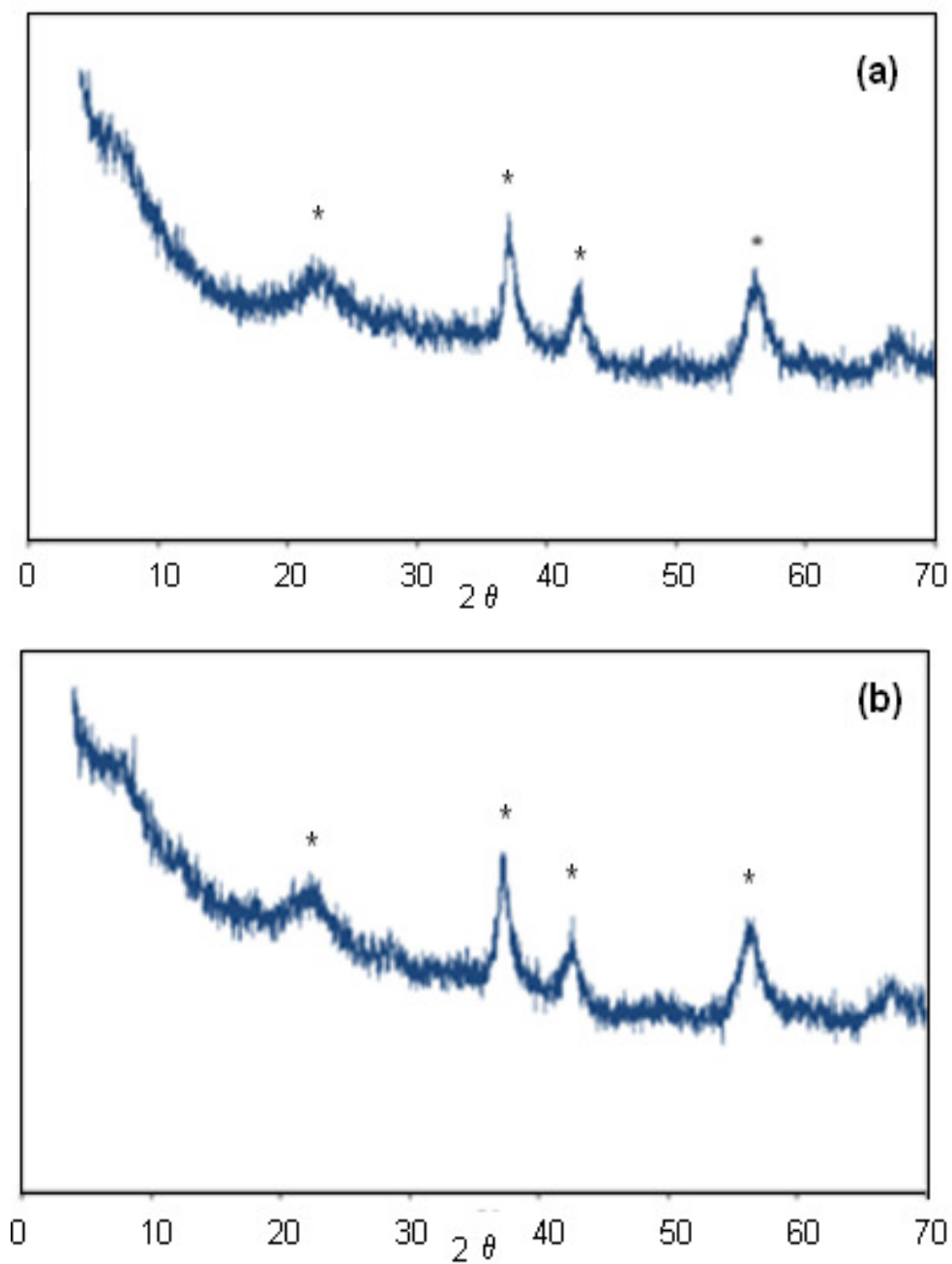

Figura 18 - Difratogramas de raios-X das amostras de DME: a) 1,93 A.dm ${ }^{-2}$ b) $2,51 \mathrm{~A} \cdot \mathrm{dm}^{-2}$ obtidos a $98^{\circ} \mathrm{C}$ por $4 \mathrm{~h}$. ( ${ }^{*}$ Picos característicos do $\varepsilon-\mathrm{MnO}_{2}$ )

$\mathrm{Na}$ análise dos difratogramas de raios- $X$ percebe-se em todas as amostras reflexões concordantes com a ficha cristalográfica JCPDS 30-0820, referente à forma alotrópica $\varepsilon-\mathrm{MnO}$. Tal fato também foi observado por Dutra e Almeida. ${ }^{(14)}$

A notação $\varepsilon-\mathrm{MnO}_{2}$ é normalmente utilizada para designar as amostras de dióxido de manganês preparado eletroquimicamente. ${ }^{(34)}$ 


\subsubsection{Microscopia eletrônica de varredura}

As amostras de DME produzidas a diferentes densidades de corrente se desprendem do anodo na forma de placas finas e irregulares, conforme pode ser observado na imagem da Figura 19.

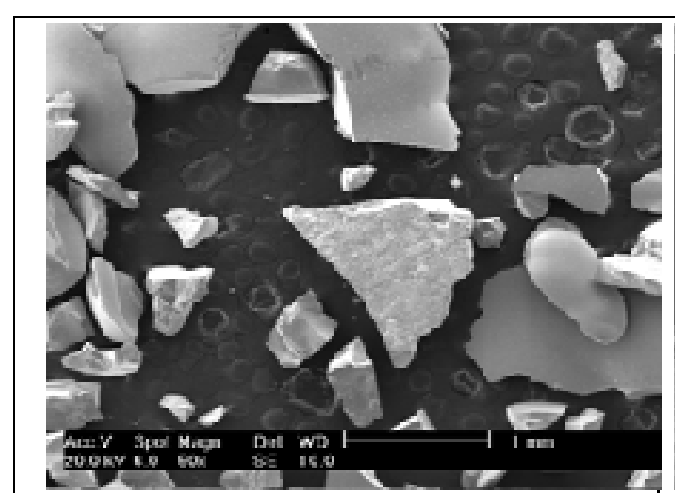

(a)

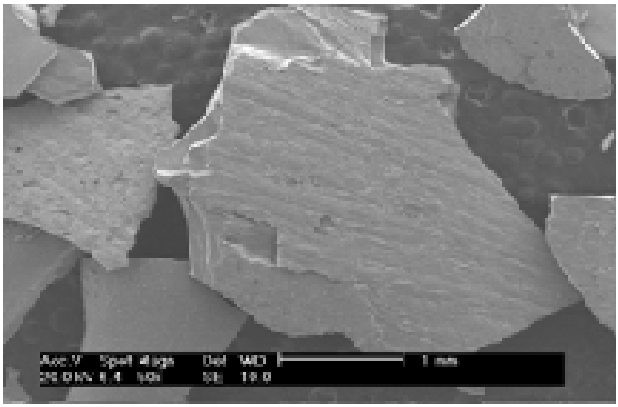

(c)

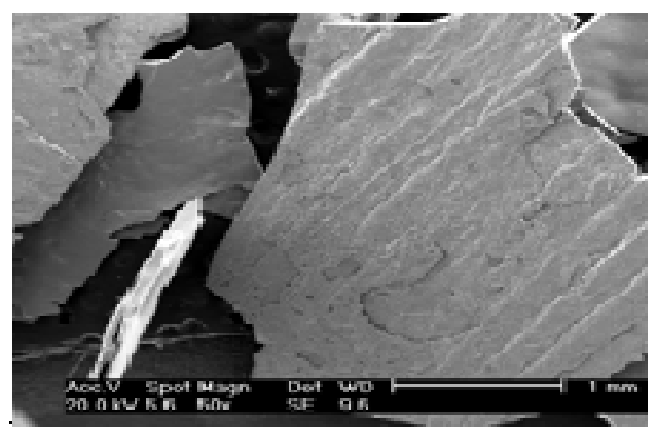

(e)

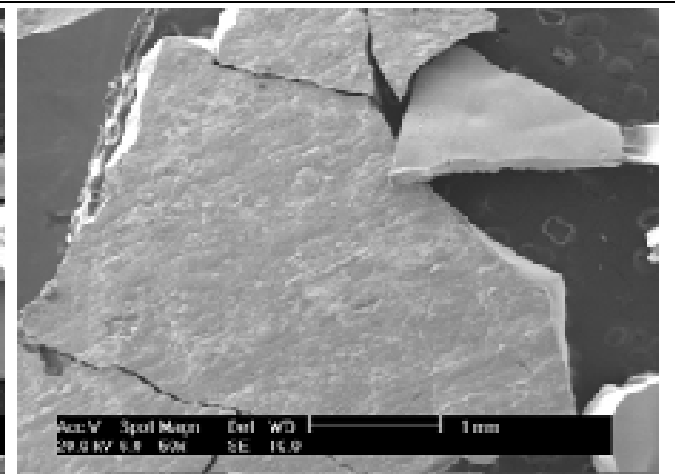

(b)

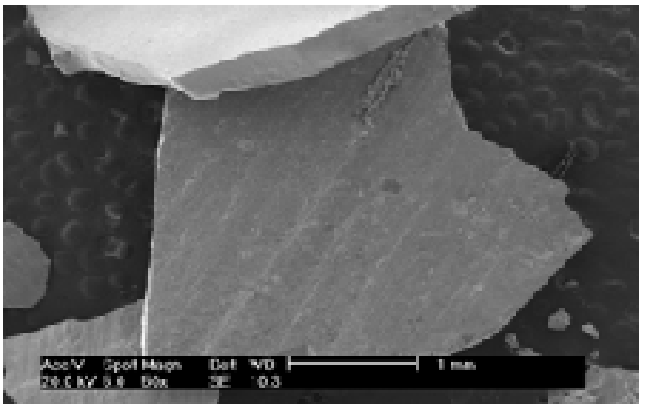

(d)

Figura 19 - Imagem de elétrons retro-espalhados. Aspecto das partículas de DME após sua remoção do eletrodo (a) 0,61 A.dm ${ }^{-2}$ (b) 1,02 A.dm ${ }^{-2}$ (c) 1,39 A.dm ${ }^{-2}$ (d) $1,93 \mathrm{~A} \cdot \mathrm{dm}^{-2}$ (e) $2,51 \mathrm{~A} \cdot \mathrm{dm}^{-2}$.

A facilidade de remoção do filme formado sobre o eletrodo aumenta com o aumento da densidade de corrente. Observou-se que o depósito formado na 
densidade de corrente $0,61 \mathrm{~A} \cdot \mathrm{dm}^{-}{ }^{2}$ fica mais aderido à superfície do eletrodo, o que dificultou a sua retirada e deu origem a fragmentos menores (Figura 20a).

A Figura 20 ( $a$ e b) e a Figura 21 ( $a, b$ e c), mostram imagens gerais das superfícies das partículas depositadas sobre o eletrodo de chumbo a diferentes densidades de corrente anódica por período de 4 horas.

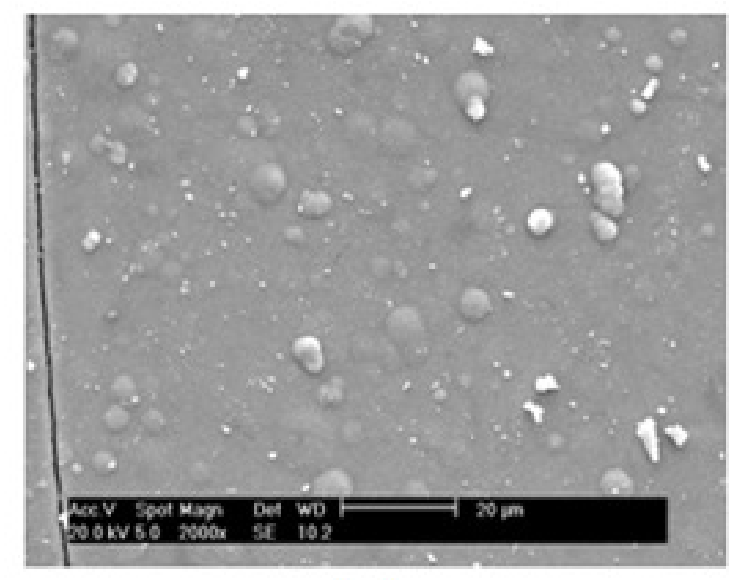

(a)

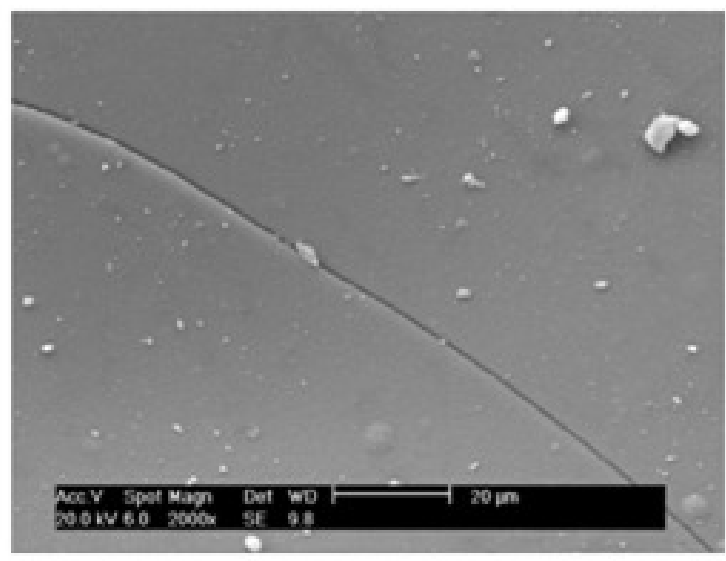

(b)

Figura 20 - Imagem de elétrons retro-espalhados. Morfologia do $\mathrm{MnO}_{2}$ obtido a $98^{\circ} \mathrm{C}$ por $4 \mathrm{~h}$.

(a) $0,61 \mathrm{~A} \cdot \mathrm{dm}^{-2}$ (b) $1,02 \mathrm{~A} \cdot \mathrm{dm}^{-2}$ 


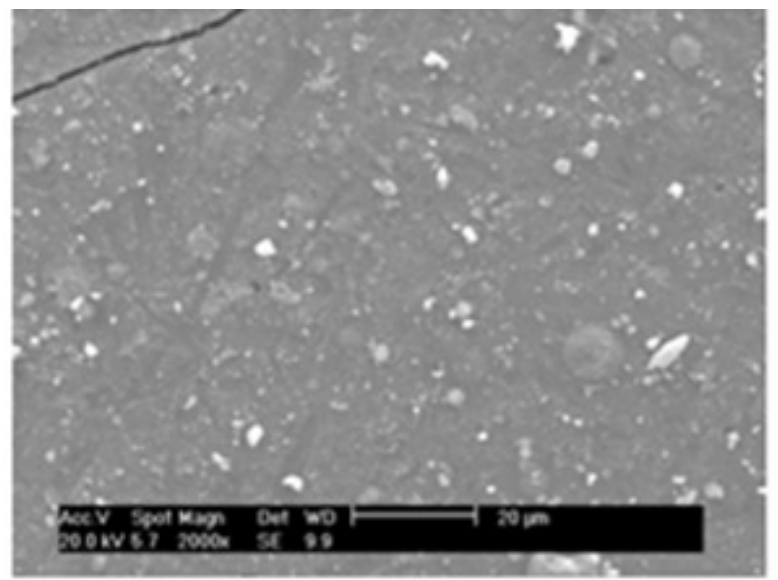

(a)

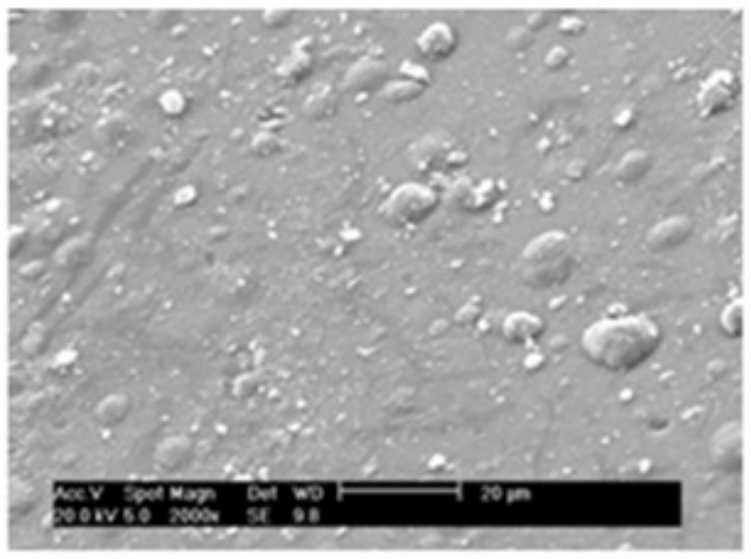

(b)

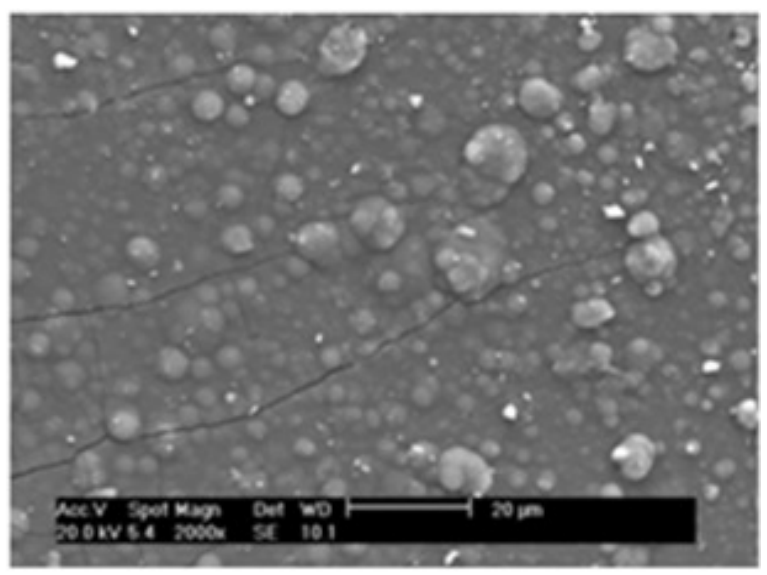

(c)

Figura 21 - Imagem de elétrons retro-espalhados. Morfologia do $\mathrm{MnO}_{2}$ obtido a $98^{\circ} \mathrm{C}$ por $4 \mathrm{~h}$. (a) 1,39 A.dm ${ }^{-2}$ (b) 1,93 A.dm ${ }^{-2}$ (c) 2,51 A.dm .

As amostras de DME apresentam, em sua superfície, rede de finas rachaduras, que surgem quando os depósitos são resfriados, após remoção do 
banho quente. Destaque-se que na maior densidade de corrente (2,51 A.dm ${ }^{-2}$ ) maior número de rachaduras no depósito é observado (Figura 21c).

O aumento da densidade de corrente leva à formação de depósitos ligeiramente dendríticos, como pode ser observado na Figura 21 (b e c). Os depósitos obtidos a uma densidade de corrente menor apresentam um aspecto mais plano - Figura 20 ( $a$ e b) e Figura 21(a), porém o depósito obtido à densidade de corrente de 1,02 apresenta uma estrutura com aspecto razoavelmente liso (Figura 20b).

A Figura 22 mostra espectros de EDS da superfície da amostra do DME obtida na densidade de corrente $0,61 \mathrm{~A}^{-\mathrm{dm}^{-2}}$ por um período de $4 \mathrm{~h}$ a $98^{\circ} \mathrm{C}$.

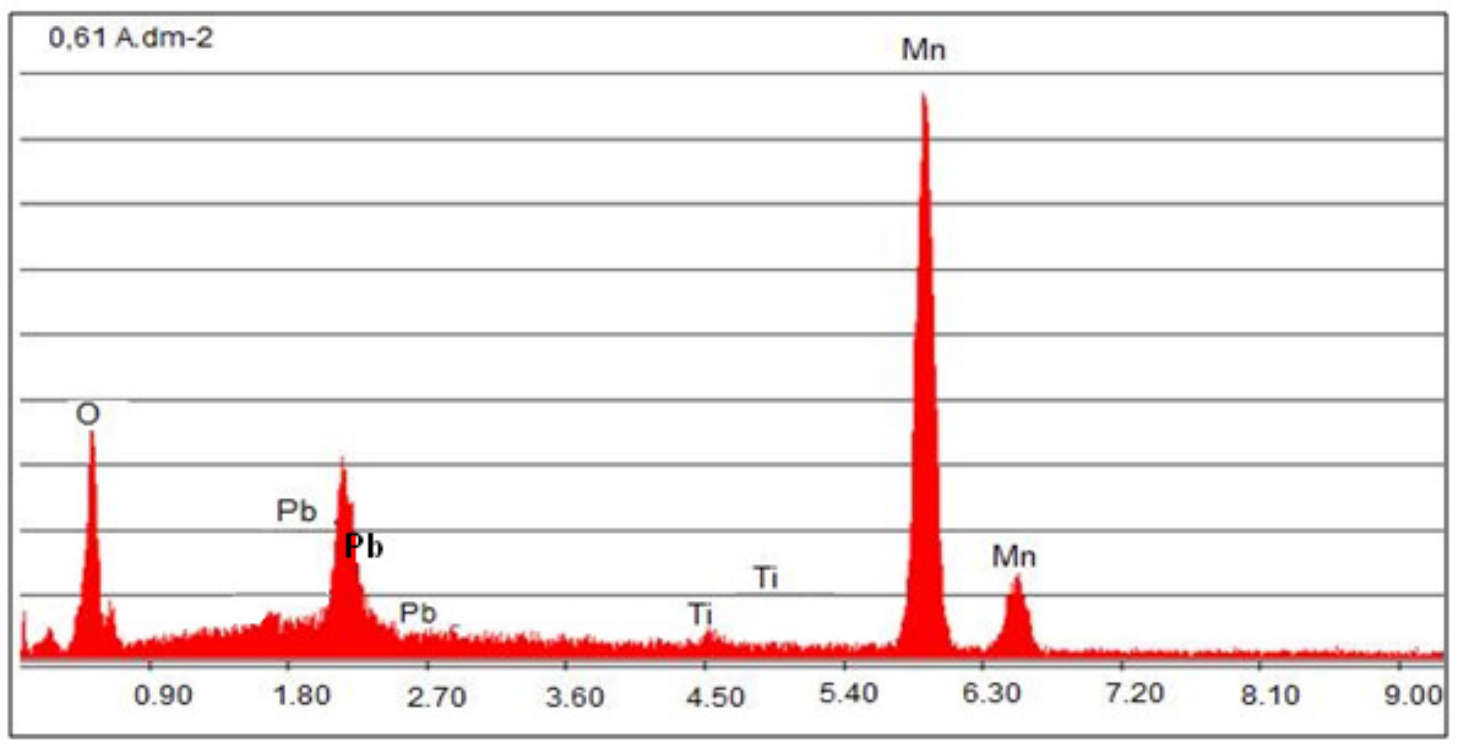

Figura 22 - Espectro de EDS da superfície do DME obtido na densidade de corrente $0,61{\mathrm{~A} . \mathrm{dm}^{-2}}^{-2}$ por um período de $4 \mathrm{~h}$ a $98^{\circ} \mathrm{C}$.

A Figura 23 ( $a$ e b) mostra espectros de EDS das superfícies das amostras do DME obtidos nas densidades de $1,02 \mathrm{~A} \cdot \mathrm{dm}^{-2} 1,39 \mathrm{~A} \cdot \mathrm{dm}^{-2}$ por um período de $4 \mathrm{~h}$ a $98^{\circ} \mathrm{C}$. 


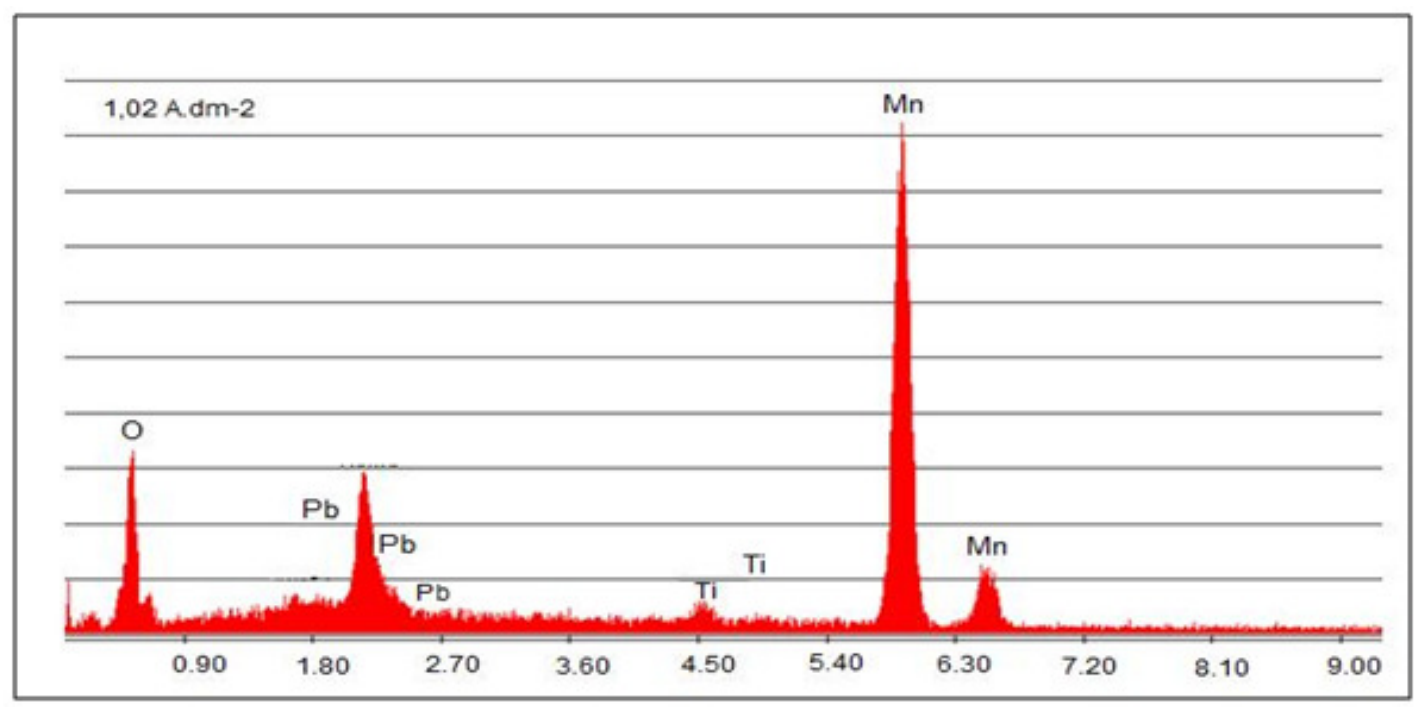

(a)

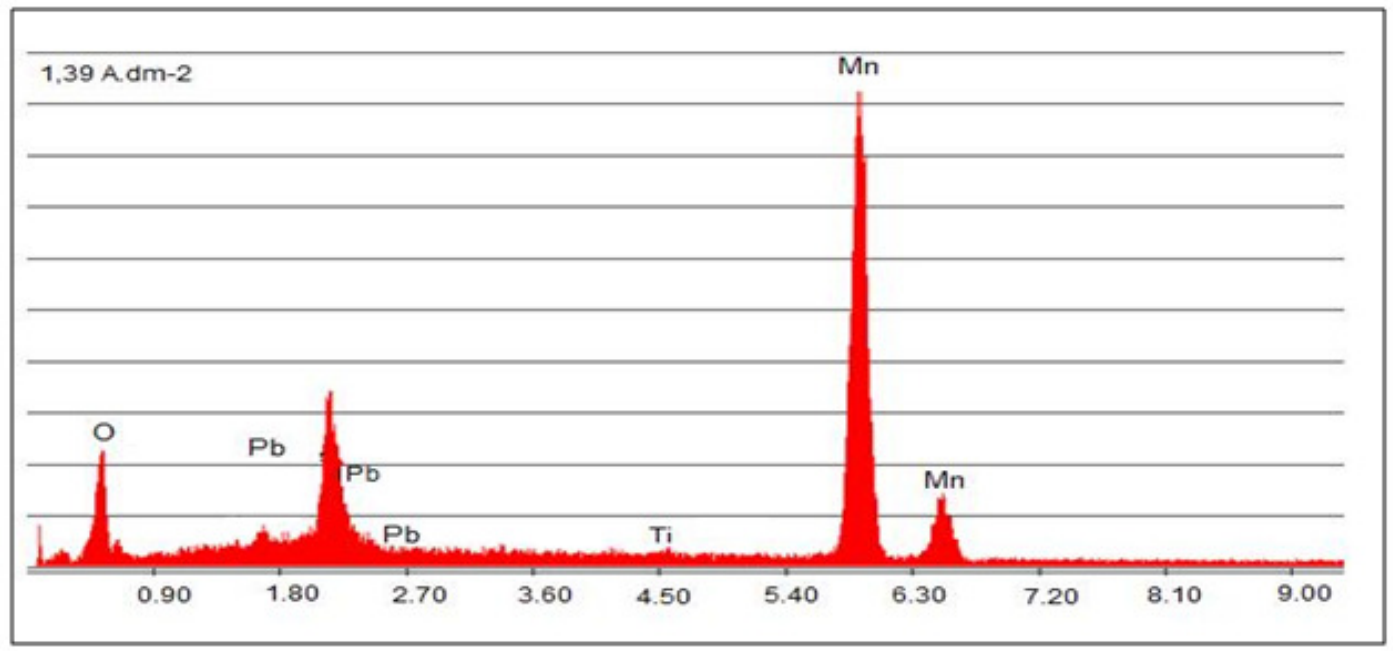

(b)

Figura 23 - Espectro de EDS do material depositado no eletrodo de chumbo a diferentes densidades de corrente por período de 4 horas. (a) 1,02 A.dm ${ }^{-2}$ (b) 1,39 A.dm .

A Figura 24 ( $a$ e b) mostra espectros de EDS das superfícies das amostras do DME obtidos nas densidades de $1,93 \mathrm{~A} \cdot \mathrm{dm}^{-2}$ e $2,51 \mathrm{~A} \cdot \mathrm{dm}^{-2}$ por um período de $4 \mathrm{~h}$ a $98^{\circ} \mathrm{C}$. 


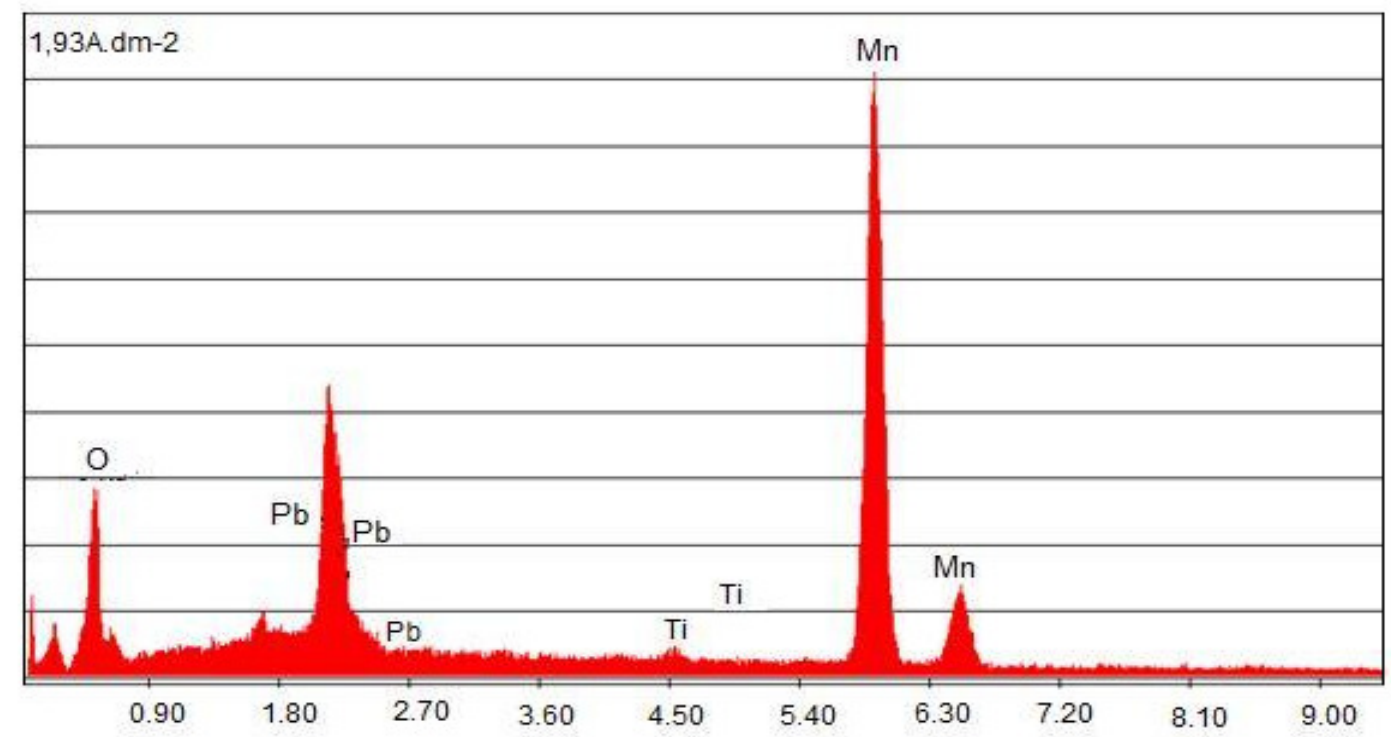

(a)

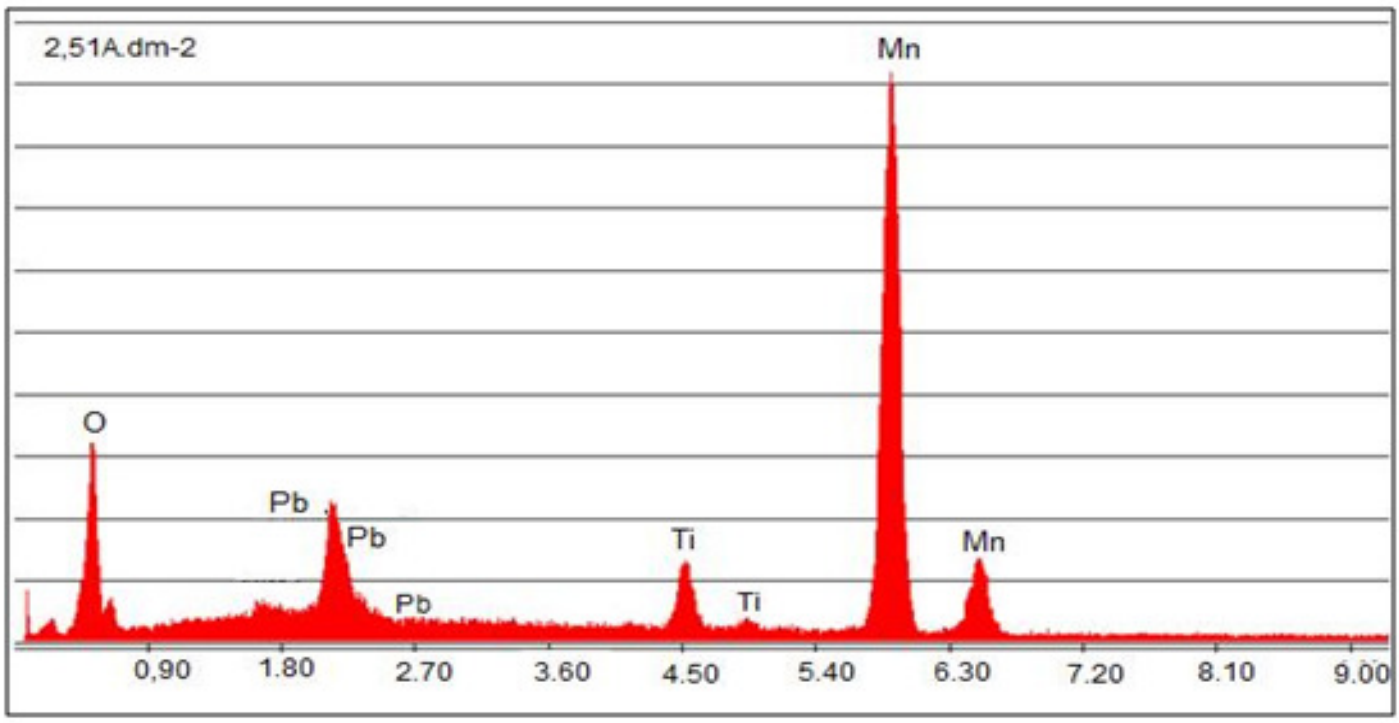

(b)

Figura 24 - Espectro de EDS do material depositado no eletrodo de chumbo a diferentes densidades de corrente por período de 4 horas. (a) 1,93 A.dm ${ }^{-2}$ (b) 2,51A.dm ${ }^{-2}$.

Os espectros de EDS das amostras indicam o manganês como elemento predominante na composição do material obtido eletroliticamente (resultado compatível com a análise química efetuada anteriormente). Também apresentam picos dos elementos chumbo e titânio como contaminantes do DME. Esse resultado indica que, durante a lavagem do material depositado, a solubilidade desses elementos diminui o que faz com que fiquem depositados sobre a superfície do depósito após a etapa de secagem. Em todas as amostras, a presença de chumbo é 
maior que a de titânio, o que sugere a contaminação do DME por esse elemento quando de sua remoção da superfície do chumbo. Esse fato pode ser confirmado observando-se a Figura 25 , que mostra a morfologia da região que ficou em contato com 0 eletrodo. Nessa imagem percebe-se uma região mais clara (A), predominantemente formada por chumbo, e outra, mais escura, $(B)$, predominantemente formada por manganês. As diferentes regiões foram caracterizadas por EDS e os seus espectros mostram a composição da área mais escura (Figura 26) e da área mais clara (Figura 27).

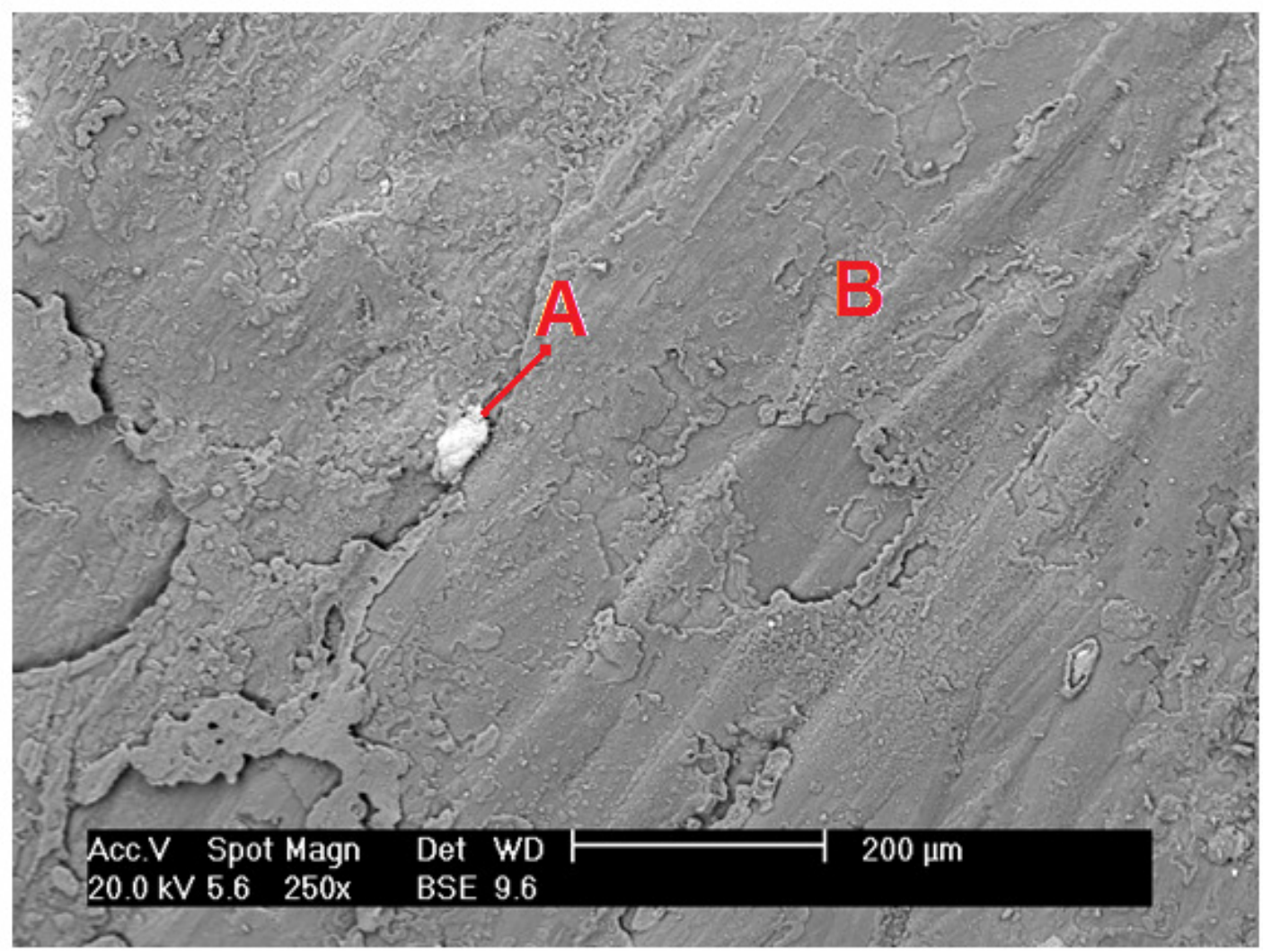

Figura 25 -Imagem de elétrons retro-espalhados. Morfologia do DME produzido a 2,51 $\mathrm{A}_{\mathrm{dm}}{ }^{-2}$. 


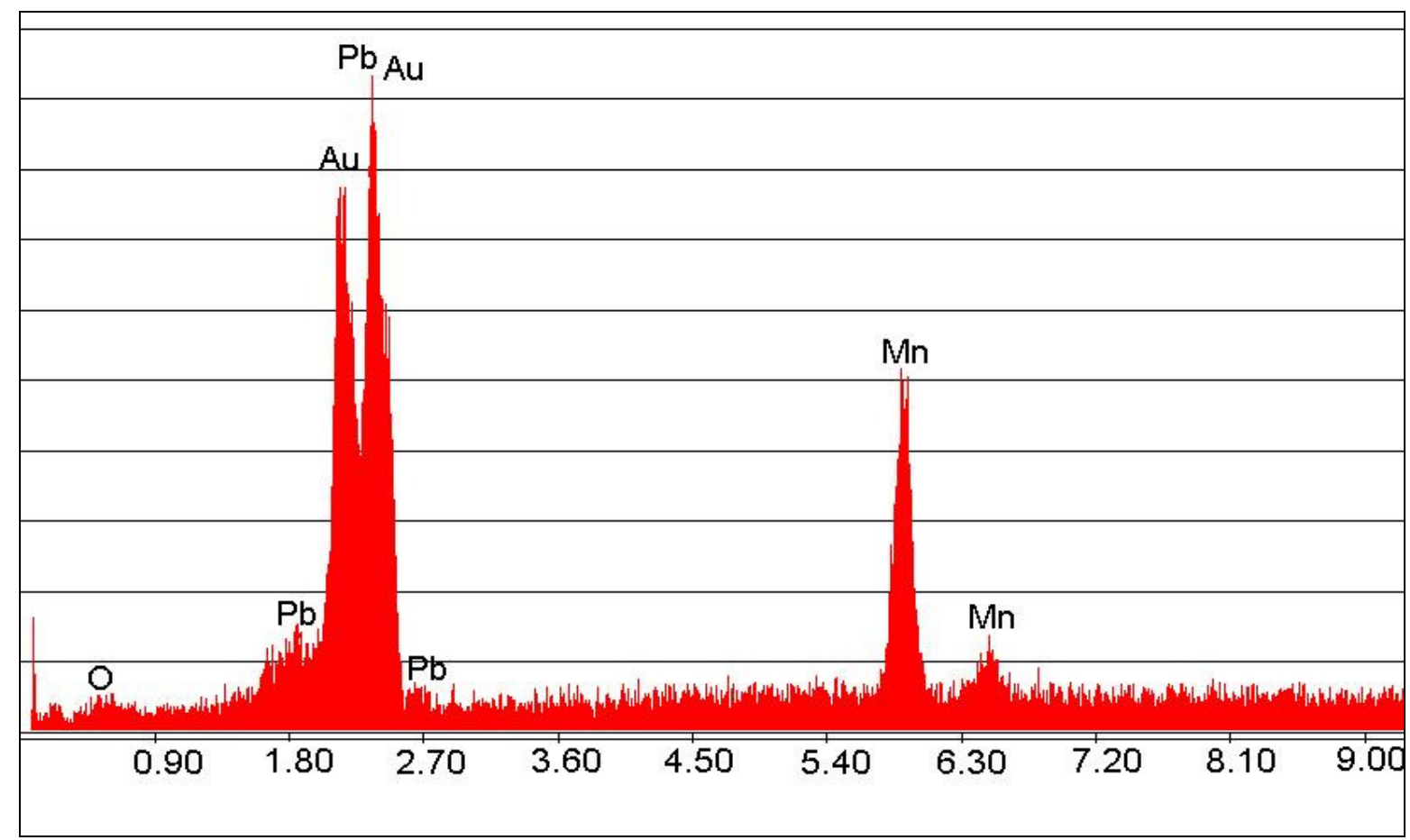

Figura 26- Espectro de EDS da região A da figura 25

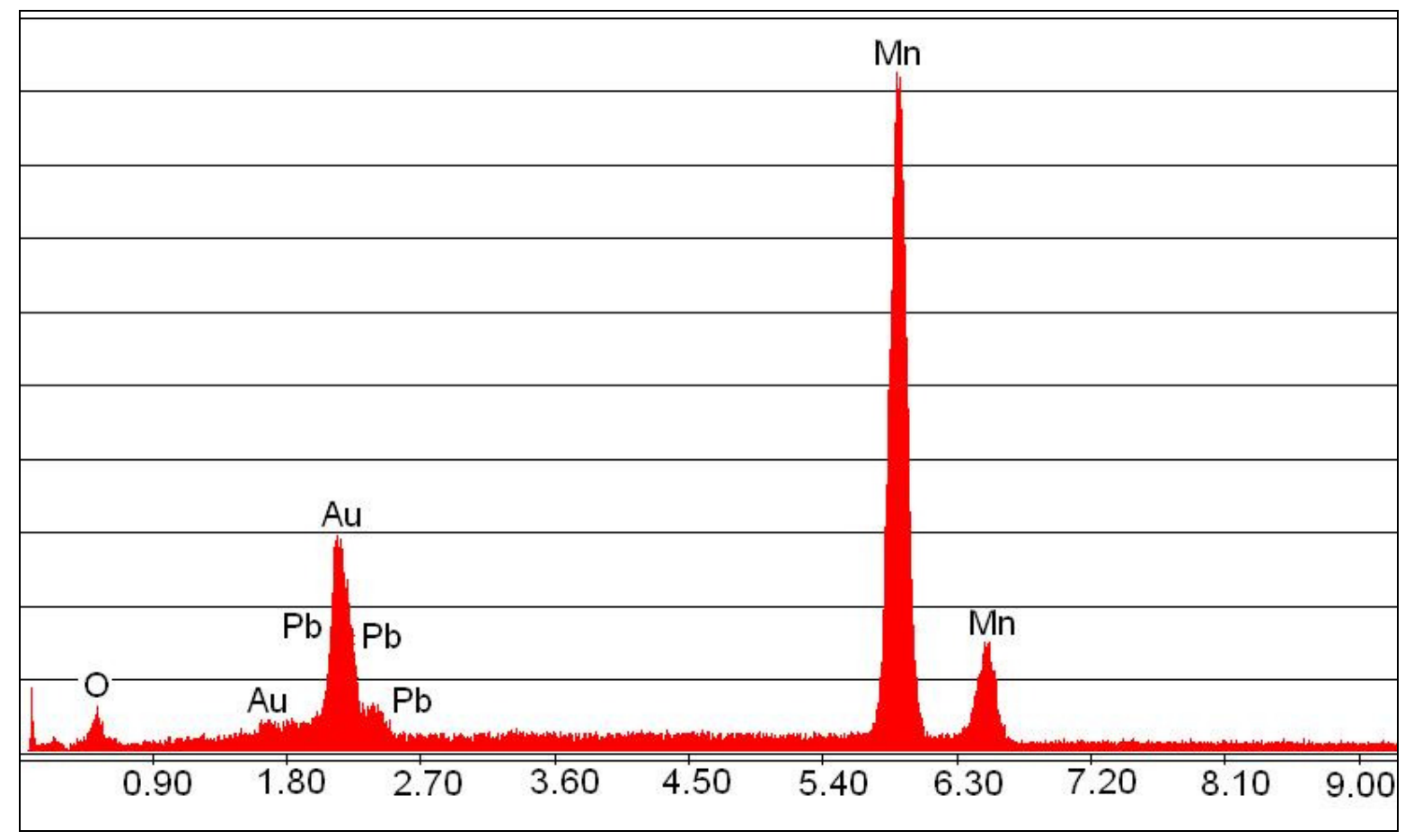

Figura 27- Espectro de EDS da região B da figura 25. 


\subsection{EFEITO DA CONCENTRAÇÃO DE ÁCIDO SULFÚRICO}

\subsubsection{Eficiência de corrente}

No intervalo de concentração de ácido sulfúrico trabalhado, obteve-se uma eficiência de corrente acima de $90 \%$ em todas as variações. Porém observa-se na Figura 28 uma eficiência máxima (97,90\%) quando a concentração de ácido sulfúrico é de 0,28 mol/L (pH 0,25).

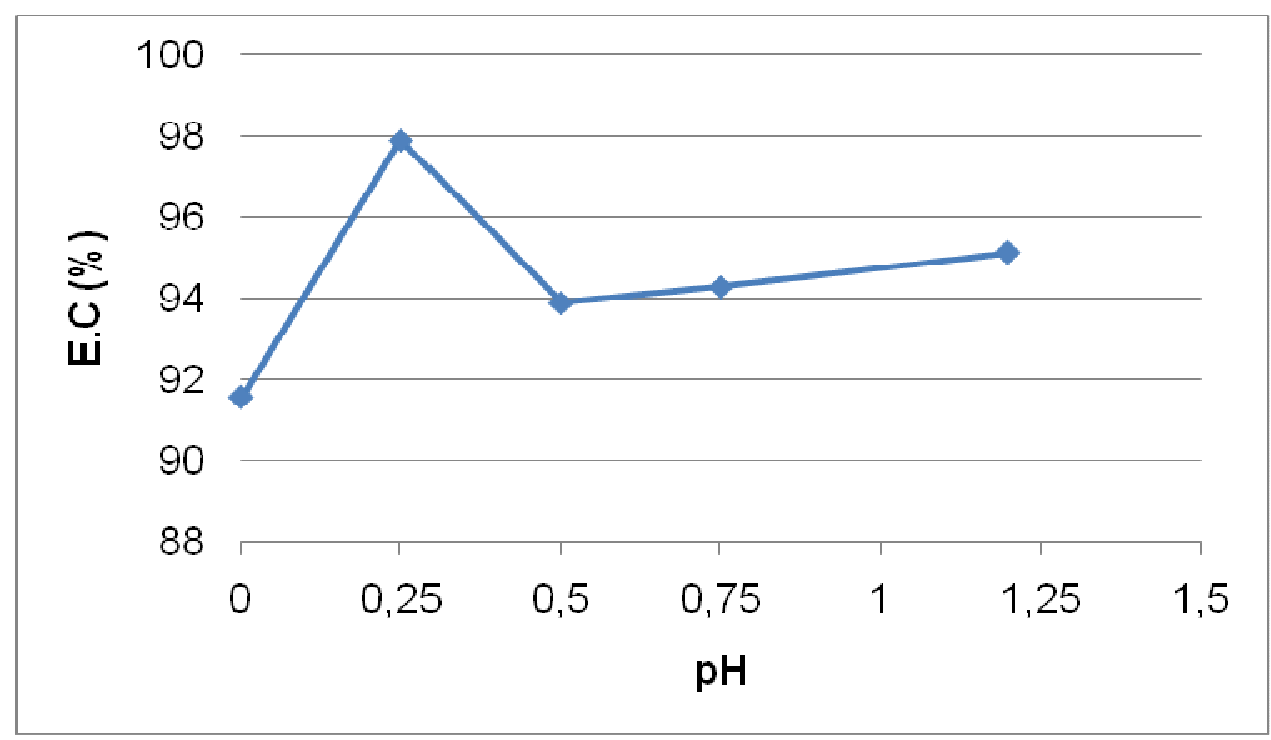

Figura 28 - Efeito do pH na eficiência de corrente.

Isto pode ser explicado devido ao fato de que, as reações envolvidas na eletrodeposição do DME são dependentes da concentração do ácido. Através da observação da reação de uma das etapas do mecanismo de deposição do $\operatorname{DME}^{(20)}$ : $\mathrm{Mn}^{3+}+2 \mathrm{H}_{2} \mathrm{O} \rightarrow \mathrm{MnOOH}+3 \mathrm{H}^{+}$, percebe-se que a estabilidade do íon $\mathrm{Mn}$ (III) é muito dependente do $\mathrm{pH}$. Em eletrólitos mais concentrados a espécie solúvel Mn(III) é mais estável para sofrer hidrólise, e assim é capaz de sofrer subsequentes oxidações ou desproporcionamento para formar $\mathrm{MnO}_{2}$. No entanto, nos eletrólitos diluídos, os íons Mn (III) são mais instáveis e, portanto, podem sofrer hidrólise mais rápida para formar um óxido de $\mathrm{Mn}(\mathrm{III})$ sólido, $\mathrm{como} \mathrm{MnOOH}{ }^{(21)}$ 
Observa-se na Figura 28 que quanto maior a concentração de ácido ( $\mathrm{pH} \mathrm{0,0)}$ a eficiência de corrente diminui. Este fenômeno também foi verificado por Owen, Lawrance e Donne ${ }^{(20)}$ que justificaram o fenômeno, afirmando que com uma vida útil mais longa, a maior parte $\mathrm{Mn}$ (III) solúvel foi perdido para do eletrólito antes de sofrer hidrólise para formar um produto sólido sobre o eletrodo.

Ao diminuir a concentração de ácido no eletrólito $(\mathrm{pH}>0,25)$ percebe-se uma tendência em diminuir a eficiência de corrente. Isto se deve ao fato de que a espécie solúvel Mn (III) torna-se mais instável e sofre hidrólise mais rápido para formar uma camada intermediária de $\mathrm{MnOOH}$. Assim, a difusão do $\mathrm{Mn}$ (II) do meio através de uma camada porosa de material sobre a superfície do DME depositado é dificultada. ${ }^{(80)}$.

Portanto é necessário identificar a faixa ideal de pH que favorece as reações de deposição do DME, que como consequencia fornecerá o máximo de eficiência no processo. Nesse experimento foi verificado que o $\mathrm{pH}$ ideal nas condições experimentais utilizadas foi de 0,25. Outro fator que se deve considerar é a relação entre as concentrações de ácido sulfúrico e as espécies $\mathrm{Mn}(\mathrm{II})$. A eficiência de corrente foi maior quando a razão entre as concentrações de $\mathrm{H}_{2} \mathrm{SO}_{4}$ e $\mathrm{MnSO}_{4}$ foi de 0,42, conforme pode ser verificado na Tabela 18 .

Tabela 18 - Efeito da razão entre as concentrações do ácido sulfúrico e sulfato de manganês na eficiência de corrente.

\begin{tabular}{|c|c|c|c|c|}
\hline $\begin{array}{l}\text { Conc. } \mathrm{H}_{2} \mathrm{SO}_{4} \\
(\mathrm{~mol} / \mathrm{L})\end{array}$ & $\mathrm{pH}$ & $\begin{array}{l}\text { Conc. } \mathrm{MnSO}_{4} \\
(\mathrm{~mol} / \mathrm{L})\end{array}$ & {$\left[\mathrm{H}_{2} \mathrm{SO}_{4}\right] /\left[\mathrm{MnSO}_{4}\right]$} & E.C (\%) \\
\hline 0,5 & 0,00 & \multirow{5}{*}{0,66} & 0,76 & 91,58 \\
\hline 0,28 & 0,25 & & 0,42 & 97,90 \\
\hline 0,16 & 0,50 & & 0,23 & 93,90 \\
\hline 0,09 & 0,75 & & 0,14 & 94,30 \\
\hline 0,03 & 1,20 & & 0,05 & 95,14 \\
\hline
\end{tabular}

\subsection{2 Área superficial específica}

Os valores de área superficial específica (ASE), determinados por B.E.T, das amostras de DME produzidas a diferentes concentrações de ácido sulfúrico são mostrados na Figura 29. 


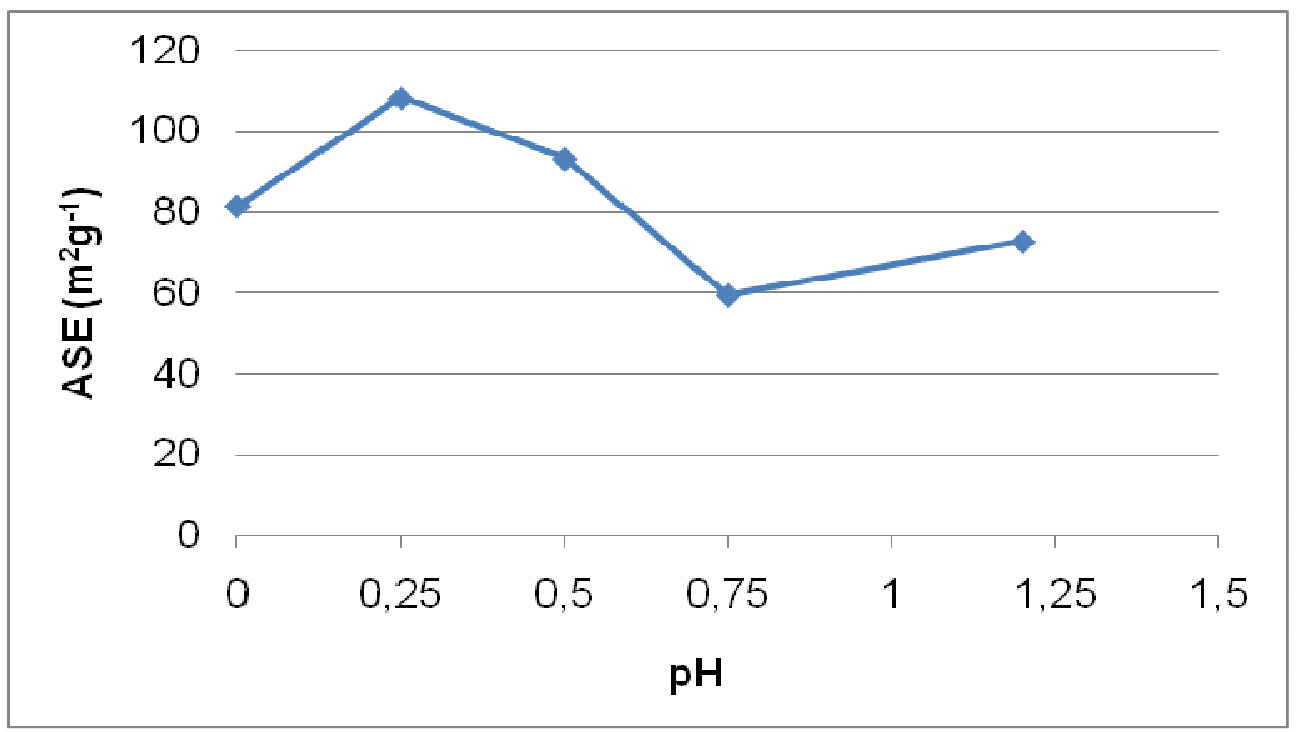

Figura 29 - Efeito do pH na área superficial do dióxido de manganês eletrolítico.

Verifica-se que a área superficial específica do DME tende a aumentar com a elevação do $\mathrm{pH}$, até o limite máximo de $108,3245 \mathrm{~m}^{2} / \mathrm{g}$ no $\mathrm{pH}$ 0,25, correspondente à concentração de $0,28 \mathrm{~mol} / \mathrm{L}$ de ácido sulfúrico. A partir desse ponto, a área superficial específica do DME tende a diminuir.

O aumento da área superficial está relacionado ao tamanho das partículas formadas no DME e consequente aumento de sua porosidade. Owen et $\mathrm{al}^{(20)}$ afirmam que a porosidade do material se correlaciona com a cristalinidade, visto que com cristalitos menores há mais contorno de grãos entre os cristalitos e, consequentemente, mais oportunidade para a presença de porosidade. Cristalitos menores são formados dentro de uma amostra quando a competição entre o crescimento do cristal e a nucleação é deslocada mais para a nucleação. Segundo os autores, a diminuição da concentração de ácido sulfúrico pode aumentar a taxa de nucleação dos cristalitos, o que forma um depósito mais poroso. Isso se deve ao fato de que em eletrólitos em que o intermediário Mn(III) solúvel é instável, há a tendência deste hidrolisar e precipitar $\mathrm{MnOOH}$. Essa instabilidade é tal que a nucleação de um cristalito novo de $\mathrm{MnOOH}$ é preferível ao crescimento contínuo dos cristalitos existentes que, aparentemente, exigem maior estabilidade de $\mathrm{Mn}(\mathrm{III})$.

Observa-se na Figura 29 que com a diminuição da concentração do ácido sulfúrico de 0,5 mol/L $(\mathrm{pH} 0,00)$ para $0,28 \mathrm{~mol} / \mathrm{L}(\mathrm{pH} 0,25)$ a área superficial aumentou de $81,6436 \mathrm{~m}^{2} \cdot \mathrm{g}^{-1}$ para $108,3245 \mathrm{~m}^{2} \cdot \mathrm{g}^{-1}$. Isso sugere a formação de um 
material composto por partículas menores e mais poroso, o que era esperado segundo a teoria descrita anteriormente.

No entanto, com a diminuição da concentração de ácido sulfúrico de $0,28 \mathrm{~mol} / \mathrm{L}(\mathrm{pH} 0,25)$ até $0,09 \mathrm{~mol} / \mathrm{L}(\mathrm{pH} 0,75)$, os resultados divergem da teoria sugerida por Owen et $\mathrm{al}^{(20)}$, pois, à medida que a concentração de ácido sulfúrico diminui, a área superficial também diminui. É provável que este fato esteja relacionado com o procedimento utilizado na remoção do material depositado sobre o eletrodo. O eletrodo de trabalho apresentava uma área superficial de $0,3 \mathrm{dm}^{2}$ e portanto o material era removido através de pequenos toques com a espátula sobre o depósito, para que se evitasse uma maior contaminação pelo chumbo proveniente do eletrodo através de raspagem. Este procedimento acarretou em amostras constituídas de partículas com tamanho muito heterogêneo.

O tamanho médio das partículas do DME calculado a partir da área superficial específica para as amostras de DME obtidas a diferentes concentração de ácidos se encontra na Tabela 19.

Tabela 19 - Tamanho médio das partículas das amostras de DME obtidas a diferentes concentrações de ácido sulfúrico.

\begin{tabular}{cccc}
\hline $\begin{array}{c}\text { Conc. Ácido } \\
\text { sulfúrico }(\mathrm{mol} / \mathrm{L})\end{array}$ & $\mathrm{pH}$ & $\begin{array}{c}\text { Área Superficial } \\
\left(\mathrm{m}^{2} \cdot \mathrm{g}^{-1}\right)\end{array}$ & $\begin{array}{c}\mathrm{D}_{\mathrm{B} . E . T} \\
(\mathrm{~nm})\end{array}$ \\
\hline 0,50 & 0,00 & 81,6436 & 15,20 \\
\hline 0,28 & 0,25 & 108,3245 & 11,47 \\
\hline 0,16 & 0,50 & 93,3064 & 13,31 \\
\hline 0,09 & 0,75 & 59,5268 & 20,87 \\
\hline 0,03 & 1,20 & 72,7804 & 17,07 \\
\hline
\end{tabular}

\subsubsection{Análise Química}

A composição química das amostras de DME produzidas a diferentes $\mathrm{pH}$ é mostrada na Tabela 20. 
Tabela 20- Resultados das análises químicas por espectrometria de fluorescência de raios- $X$ das amostras de DME obtidas em diferentes $\mathrm{pH}$ (dados em porcentagem em massa)

\begin{tabular}{cccccc}
\hline Composição & $\mathrm{pH}=0,00$ & $\mathrm{pH}=0,25$ & $\mathrm{pH}=0,50$ & $\mathrm{pH}=0,75$ & $\mathrm{pH}=1,2$ \\
\hline $\mathrm{F}$ & $\mathrm{nd}$ & 1,52 & 1,03 & 2,33 & 1,42 \\
\hline $\mathrm{Na}$ & $\mathrm{nd}$ & $\mathrm{nd}$ & $\mathrm{nd}$ & 0,02 & $\mathrm{nd}$ \\
\hline $\mathrm{Al}$ & 0,01 & $\mathrm{nd}$ & $\mathrm{nd}$ & $\mathrm{nd}$ & 0,01 \\
\hline $\mathrm{Si}$ & 0,04 & 0,03 & 0,02 & 0,03 & 0,04 \\
\hline $\mathrm{P}$ & 0,01 & $<<$ & $<<$ & $<<$ & $<<$ \\
\hline $\mathrm{S}$ & 0,98 & 0,75 & 0,44 & 0,94 & 0,91 \\
\hline $\mathrm{K}$ & 0,17 & 0,14 & 0,11 & 0,15 & 0,12 \\
\hline $\mathrm{Ca}$ & 0,02 & 0,01 & $\mathrm{nd}$ & 0,01 & 0,01 \\
\hline $\mathrm{Ti}$ & 0,45 & 0,45 & 0,17 & 0,24 & 0,35 \\
\hline $\mathrm{MnO} \mathrm{H}_{2}$ & 97,30 & 96,30 & 97,64 & 95,45 & 96,11 \\
\hline $\mathrm{Fe}$ & 0,14 & 0,18 & 0,10 & 0,17 & 0,16 \\
\hline $\mathrm{Co}$ & 0,09 & 0,15 & 0,10 & 0,13 & 0,12 \\
\hline $\mathrm{Ni}$ & 0,14 & 0,13 & 0,06 & 0,08 & 0,15 \\
\hline $\mathrm{Zn}$ & $\mathrm{nd}$ & $\mathrm{nd}$ & $\mathrm{nd}$ & $\mathrm{nd}$ & $\mathrm{nd}$ \\
\hline $\mathrm{Pb}$ & 0,65 & 0,34 & 0,33 & 0,45 & 0,60 \\
\hline & & & & &
\end{tabular}

A analise dos resultados mostra que o teor de pureza do dióxido de manganês obtido nas condições dos experimentos foi superior a $90 \%$ para todas as amostras de DME. Porém, os melhores resultados obtidos, quanto à concentração de $\mathrm{MnO}_{2}$, foram verificados nas amostras produzidas nos banhos eletrolíticos que apresentavam concentração de ácido sulfúrico de $0,50 \mathrm{~mol} / \mathrm{L}(\mathrm{pH} \quad 0,0)$ e de $0,16 \mathrm{~mol} / \mathrm{L}$ ( $\mathrm{pH} 0,50$ ). Os valores obtidos foram $97,30 \%$ e $97,64 \%$ respectivamente. Isso pode ser observado na Figura 30, que mostra o efeito da concentração do ácido $(\mathrm{pH})$ sobre a contaminação dos íons metálicos dissolvidos no banho eletrolítico. Verifica-se que em pH 0,5 ocorre a menor contaminação dos íons metálicos no DME.

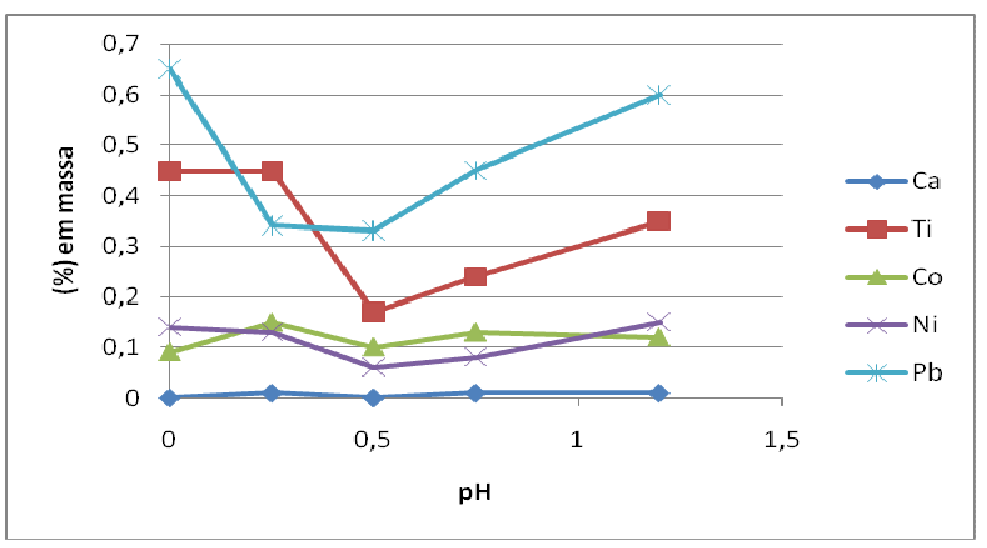

Figura 30- Efeito do pH na incorporação das impureza metálicas no DME. 


\subsubsection{Difração de Raios -X}

A Figura 31 mostra o difratogramas do pó de DME obtido a pH 0,0, por $7 \mathrm{~h}$, a $98^{\circ} \mathrm{C}$.

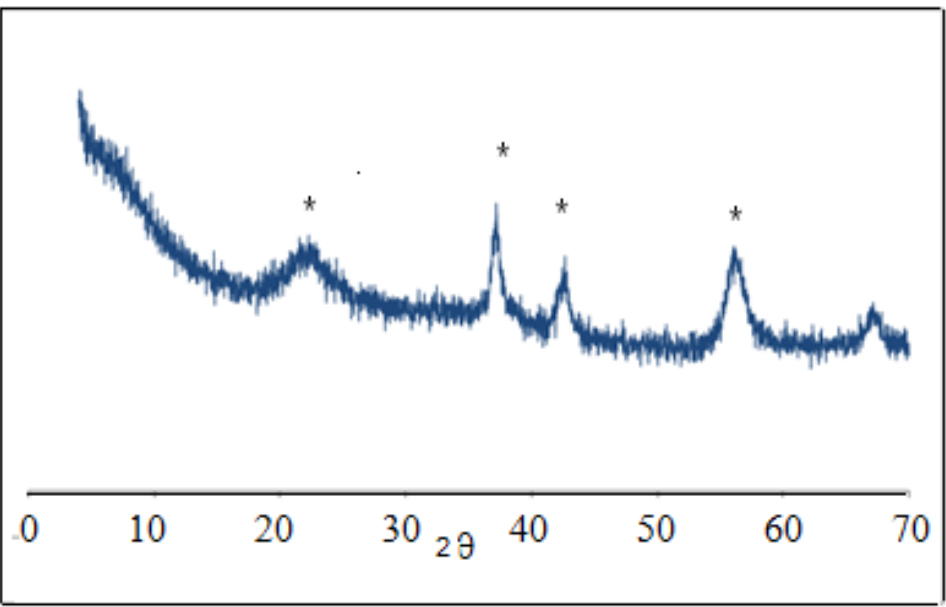

Figura 31 - Difratograma de raios-X da amostra de DME obtido a pH 0,0 , por $7 \mathrm{~h}$ a $98^{\circ} \mathrm{C}$. * Picos característicos do $\varepsilon-\mathrm{MnO}_{2}$.

A Figura 32 ( $a, b$ e c) mostra os difratogramas do pós de DME obtidos a $\mathrm{pH} 0,25$; $\mathrm{pH} 0,50$ e $\mathrm{pH} 0,75$ por $7 \mathrm{~h}$, a $98^{\circ} \mathrm{C}$. 

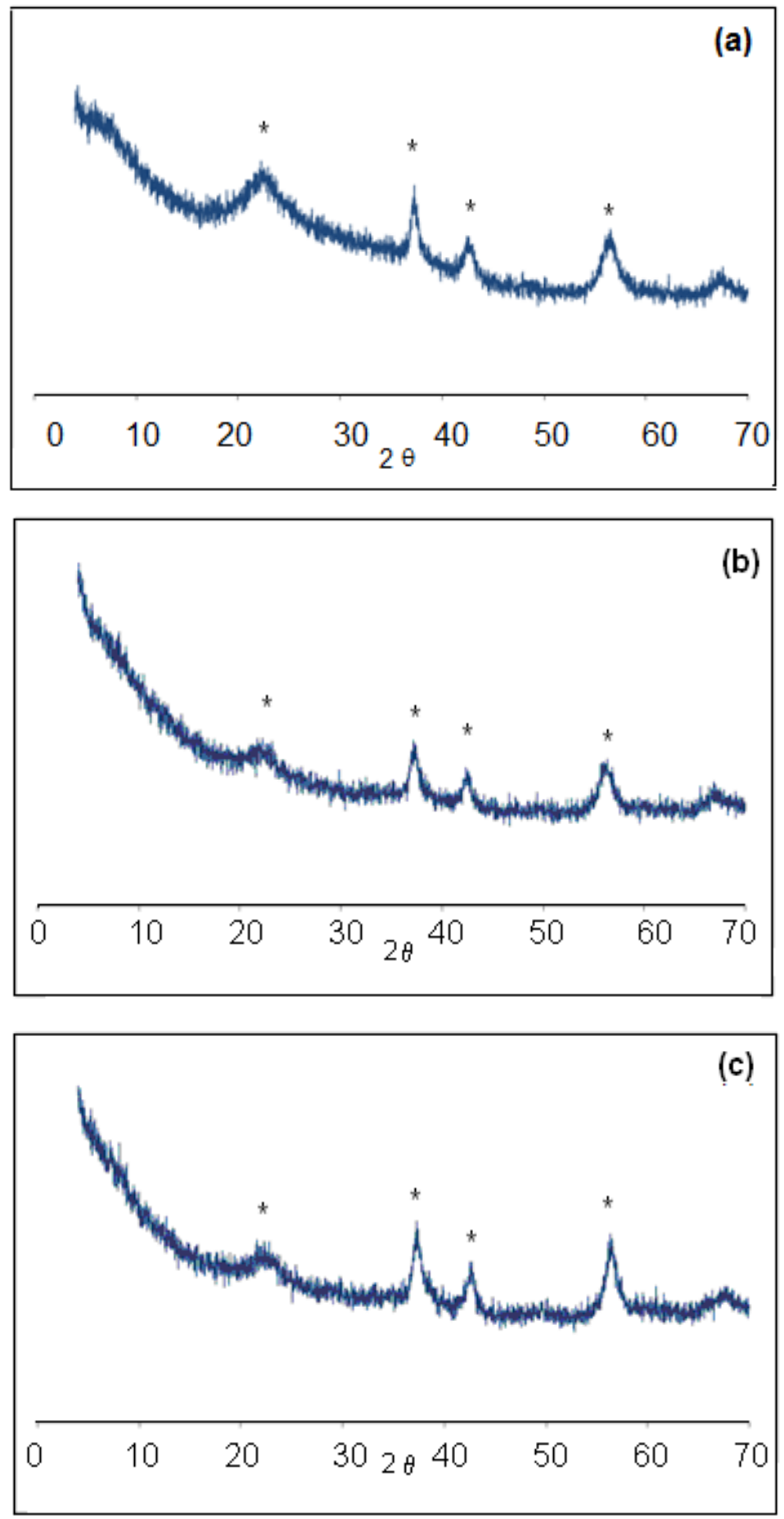

Figura 32 - Difratogramas de raios- $X$ das amostras de DME obtidos a $98^{\circ} \mathrm{C}$, por $7 \mathrm{~h}:$ a) $\mathrm{pH} 0,25$; b) $0,50 \mathrm{c}) \mathrm{pH} 0,75 .{ }^{*}$ Picos característicos do $\varepsilon-\mathrm{MnO}_{2}$.

A Figura 33 mostra o difratograma do pó de DME obtido a $\mathrm{pH} 1,20$, por $7 \mathrm{~h}$, a $98^{\circ} \mathrm{C}$. 


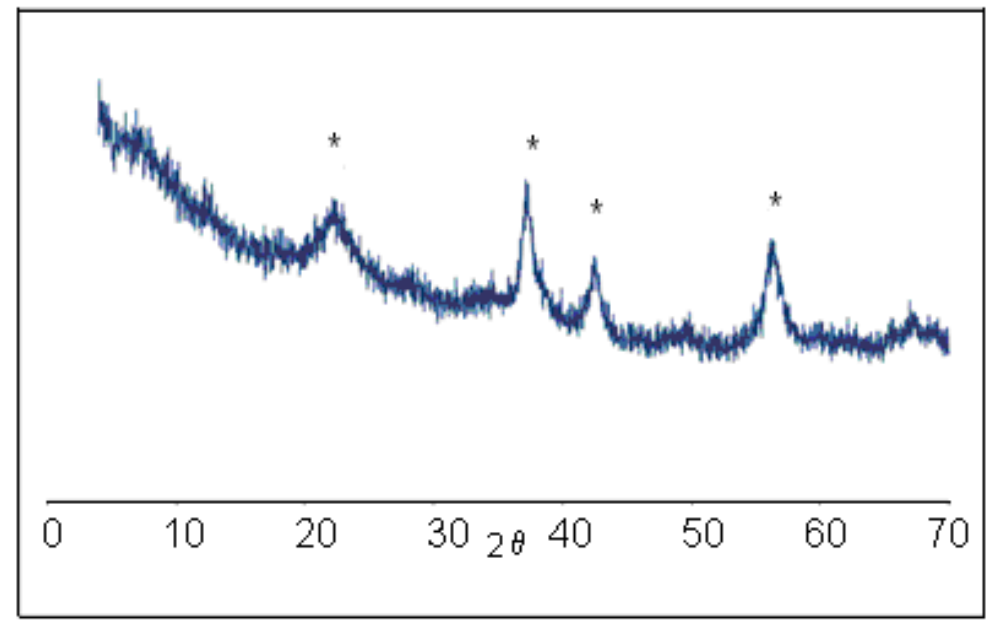

Figura 33 - Difratogramas de raios- $\mathrm{X}$ da amostra de DME obtido a $\mathrm{pH} 1,20$ por $7 \mathrm{~h}$ a $98^{\circ} \mathrm{C}$. ${ }^{*}$ Picos característicos do $\varepsilon-\mathrm{MnO}_{2}$.

Como se pode observar nas Figuras 31,32 e 33 , as variações na concentração do ácido sulfúrico nos banhos eletrolíticos de $0,5 \mathrm{~mol} / \mathrm{L}(\mathrm{pH} 0,0)$ a $0,03 \mathrm{~mol} / \mathrm{L}(\mathrm{pH} 1,20)$ não afetaram a estrutura do DME obtido. Em todas as amostras há predominância da forma $\varepsilon$ do $\mathrm{MnO}_{2}$ (JCPDS 30-0820).

\subsubsection{Microscopia de varredura eletrônica}

Uma imagem mais detalhada da aparência da superfície das amostras do DME produzidas à diferentes concentrações de ácido sulfúrico é dada pelo microscópio eletrônico de varredura (Figura 34 a,b,c,d,e). 


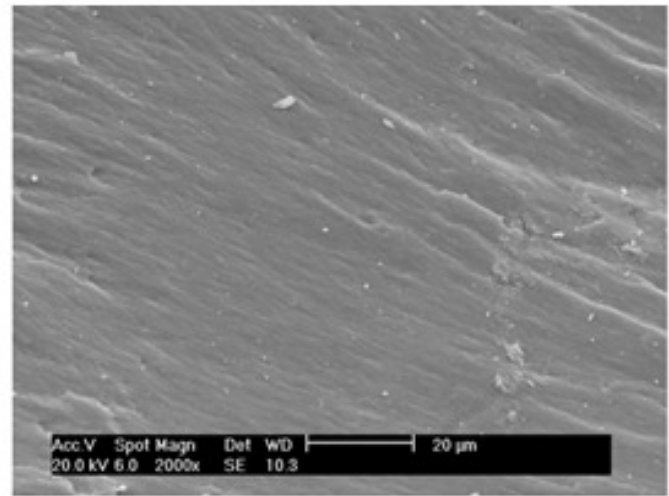

(a)

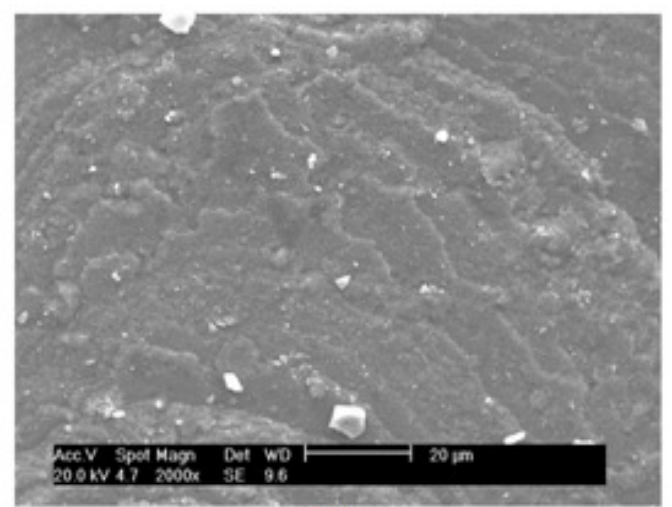

(c)

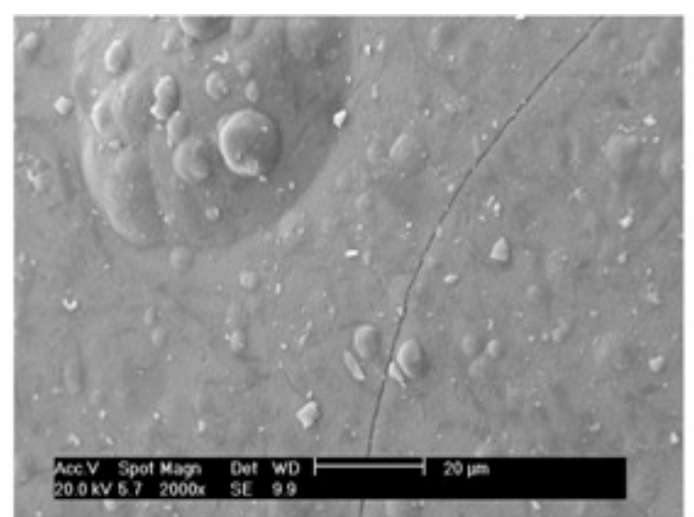

(b)

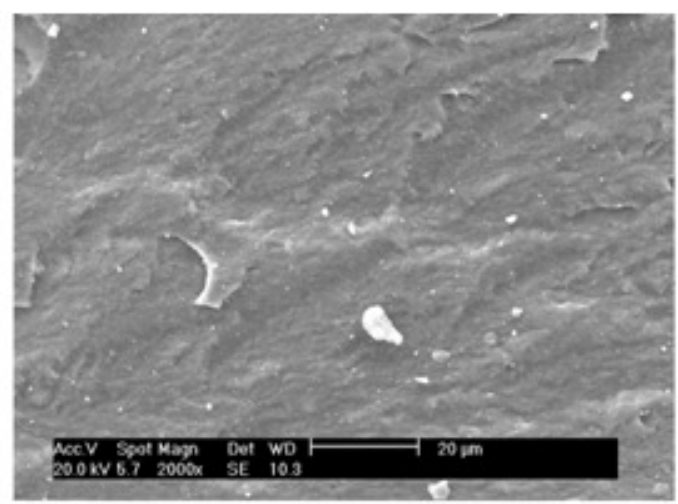

(d)

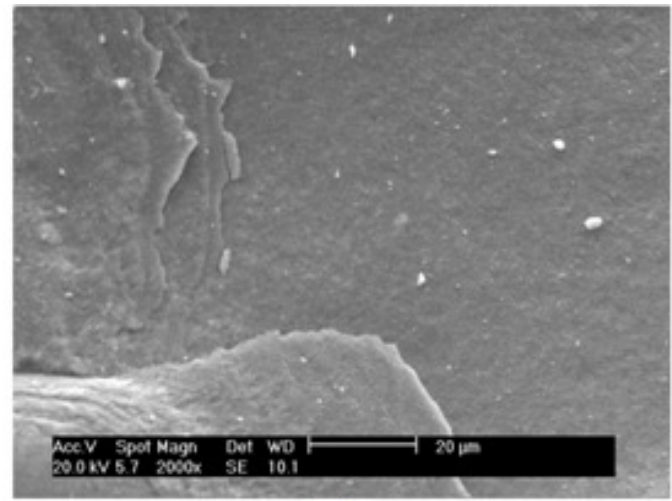

(e)

Figura 34 - Imagem de elétrons retro-espalhados. Morfologia do $\mathrm{MnO}_{2}$ eletrodepositado a diferentes concentrações de ácido sulfúrico, a $98^{\circ} \mathrm{C}$, por $7 \mathrm{~h}$. a) $0,5 \mathrm{~mol} / \mathrm{L}$ ( $\left.\mathrm{pH} 0.00\right)$; b) $0,28 \mathrm{~mol} / \mathrm{L}(\mathrm{pH} 0,25)$;

c) $0,16 \mathrm{~mol} / \mathrm{L}(\mathrm{pH} 0,50) ; \mathrm{d}) 0,09 \mathrm{~mol} / \mathrm{L}(\mathrm{pH} 0,75) ;$ e) $0,03 \mathrm{~mol} / \mathrm{L}(\mathrm{pH} 1,20)$.

Os depósitos de DME formados apresentam aspecto bastante denso (Figura 34 a,c,d,e), exceto para a amostra produzida no banho cuja concentração de ácido sulfúrico foi de $0,28 \mathrm{~mol} / \mathrm{L}(\mathrm{pH} \mathrm{0,25)}$. Através dos dados obtidos na determinação da 
área específica BET (Figura 29), percebe-se que a maior área $\left(108,3245 \mathrm{~m}^{2} \cdot \mathrm{g}^{-1}\right)$ corresponde ao DME que apresenta a estrutura da Figura 34b.

Espectros de EDS das superfícies das amostras do DME obtidas em concentrações de ácido sulfúrico $0,5 \mathrm{~mol} / \mathrm{L}(\mathrm{pH} 0.0)$ e 0,28mol/L (pH 0,25) são mostrados na Figura 35.
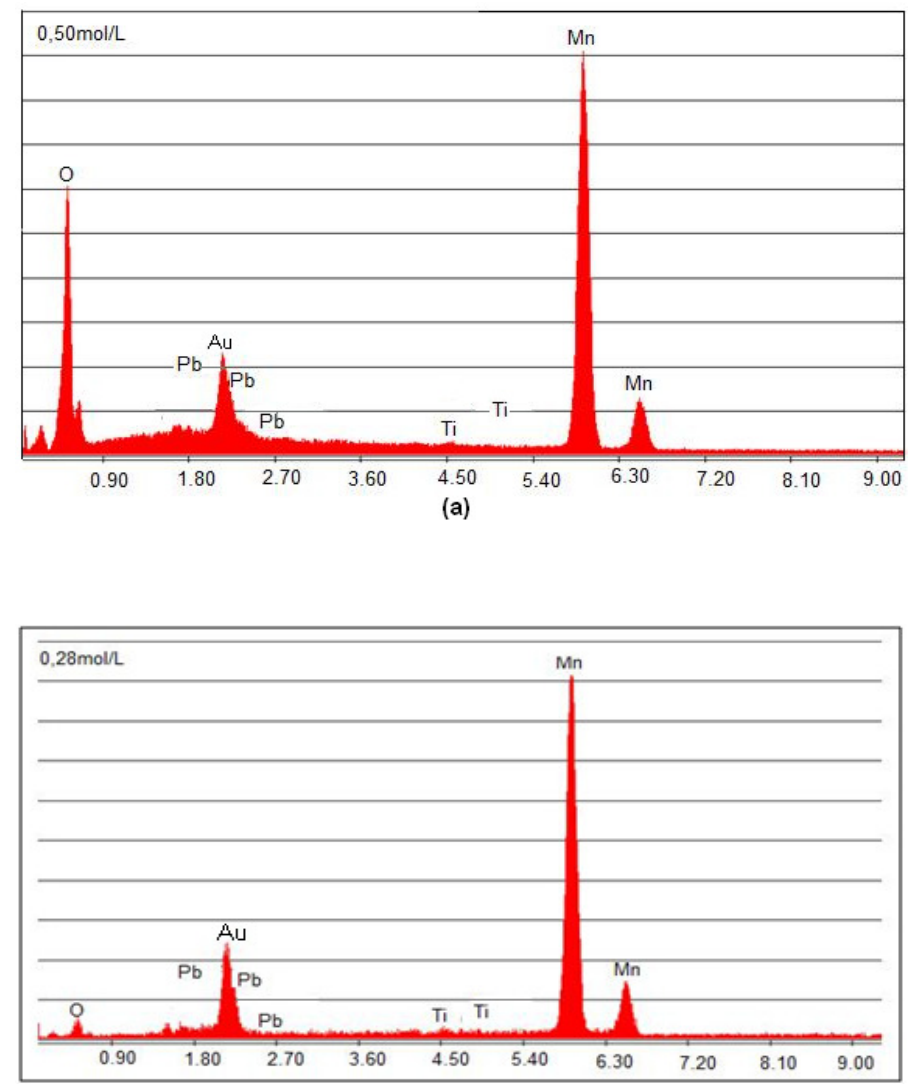

(b)

Figura 35 - Espectro de EDS do material depositado no eletrodo de chumbo a diferentes concentrações de ácido sulfúrico, a $98^{\circ} \mathrm{C}$, por período de 7 horas. (a) 0,5 mol/L(pH 0.00) e b) $0,28 \mathrm{~mol} / \mathrm{L}(\mathrm{pH} 0,25)$.

Espectros de EDS das superfícies das amostras do DME obtidas em concentrações de ácido sulfúrico $0,16 \mathrm{~mol} / \mathrm{L}(\mathrm{pH} \mathrm{0,50);0,09mol} / \mathrm{L}(\mathrm{pH} 0,75) ; \mathrm{e}$ 0,03mol/L (pH 1,20) são mostrados na Figura 36. 


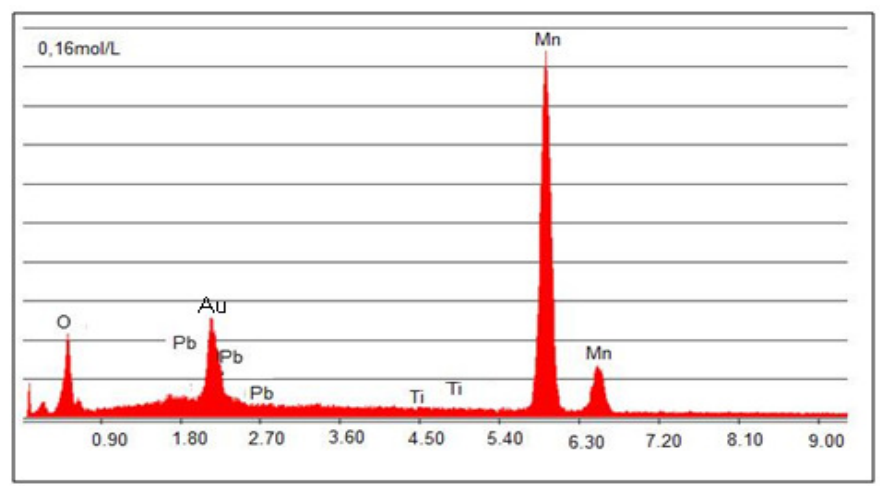

(a)

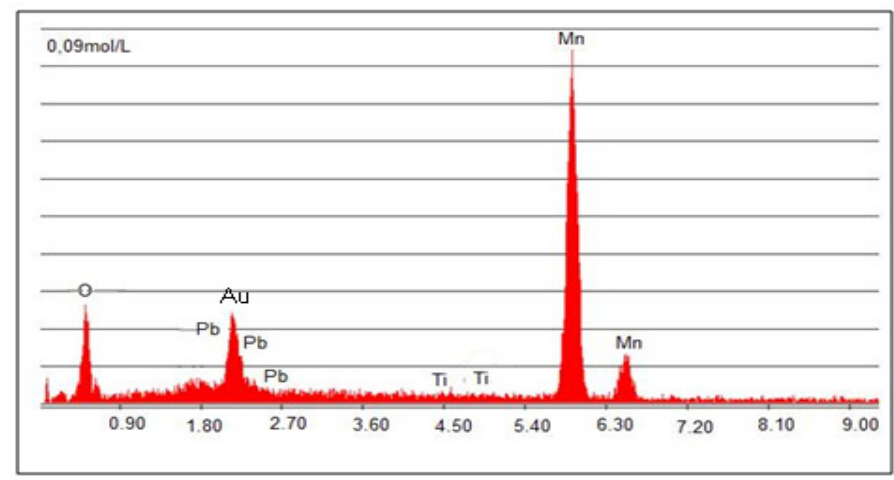

(b)

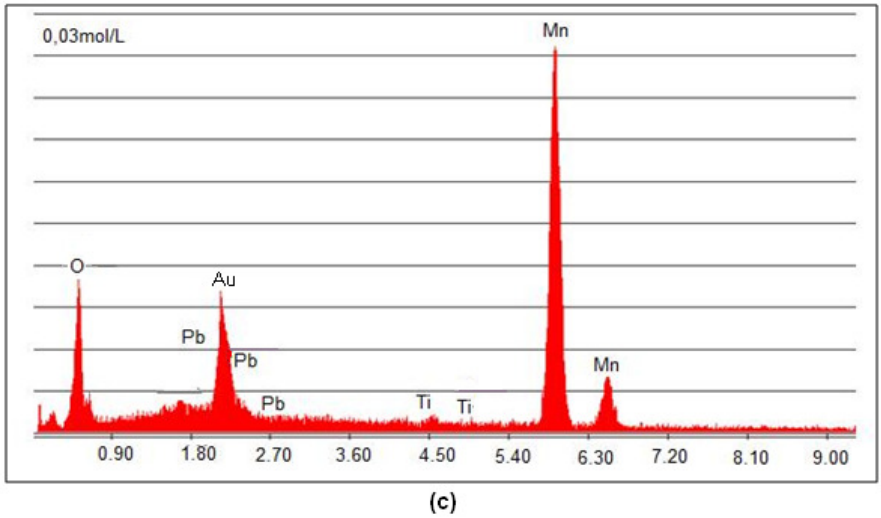

Figura 36 - Espectro de EDS do material depositado no eletrodo de chumbo a diferentes concentrações de ácido sulfúrico, a 98ํㅡ, por período de 7 horas a) 0,16mol/L (pH 0,50);

b) $0,09 \mathrm{~mol} / \mathrm{L}(\mathrm{pH} 0,75)$; c) $0,03 \mathrm{~mol} / \mathrm{L}(\mathrm{pH} \mathrm{1,20)}$

Os espectros de EDS das diferentes amostras foram semelhantes. A presença de picos de elementos como chumbo e titânio indica que esses elementos não foram totalmente removidos da superfície do DME durante o processo de lavagem. Os espectros de EDS indicam o manganês como elemento predominante na composição das amostras obtidas eletroliticamente. 


\section{CONCLUSÕES}

Com base nos resultados alcançados pode-se concluir:

1. É possível, com a técnica de eletrólise, a recuperação do manganês na forma de dióxido de manganês eletrolítico a partir do reaproveitamento de pilhas e baterias exauridas.

2. Os melhores valores de eficiência de corrente $(94,3 \%$ e $89,4 \%)$ e as maiores áreas superficiais específicas $\left(150,8519\right.$ e $\left.131,5430 \mathrm{~m}^{2} \cdot \mathrm{g}^{-1}\right)$ são obtidos quando aplicada densidade de corrente entre 1,02-1,39 A.dm ${ }^{-2}$.

3. As amostras de DME obtidas com variação de densidade de corrente entre $0,61 \mathrm{~A} \cdot \mathrm{dm}^{-2}$ e $2,51 \mathrm{~A} \cdot \mathrm{dm}^{-2}$ apresentaram teor de pureza superior a $90 \%$.

4. A variação na densidade de corrente entre $0,61 \mathrm{~A} \cdot \mathrm{dm}^{-2}$ e $2,51 \mathrm{~A} \cdot \mathrm{dm}^{-2}$ não afetou a estrutura do DME obtido. Em todas as amostras há predominância da forma $\varepsilon$ do $\mathrm{MnO}_{2}$.

5. No pH 0,25, obteve-se a melhor eficiência de corrente $(97,90 \%)$ e a maior área superficial específica $\left(108,3245 \mathrm{~m} 2 \cdot \mathrm{g}^{-1}\right)$.

6. Os melhores resultados obtidos quanto à concentração de $\mathrm{MnO}_{2}(97,30 \% \mathrm{e}$ $97,64 \%)$ se verificaram nas amostras produzidas nos banhos eletrolíticos cujas concentrações de ácido sulfúrico foram de $0,50 \mathrm{~mol} / \mathrm{L}(\mathrm{pH} \mathrm{0,0)}$ e de $0,16 \mathrm{~mol} / \mathrm{L}(\mathrm{pH} 0,5)$, respectivamente.

7. As variações na concentração do ácido sulfúrico no banho eletrolítico, entre 0,5mol/L ( $\mathrm{pH} \mathrm{0,00)} \mathrm{e} \mathrm{0,03mol/L} \mathrm{(pH} \mathrm{1,20),} \mathrm{não} \mathrm{afetaram} \mathrm{a} \mathrm{estrutura} \mathrm{do} \mathrm{DME}$ obtido. Em todas as amostras há predominância da forma $\varepsilon$ do $\mathrm{MnO}_{2}$. 
8. Dos elementos presentes na solução, chumbo e titânio são os principais contaminantes da superfície das amostras do DME obtidas a diferentes densidades de corrente e a diferentes concentrações de ácido sulfúrico 


\section{REFERÊNCIAS BIBLIOGRÁFICAS}

1 STROBEL, P.; IBARRA-PALOS, A.; ANNE, M.; POINSIGNON, C.; CRISCI, A.. Cation ordering in Li2Mn3MO8 spinels: structural and vibration spectroscopy studies. Solid State Sciences 5, 1009-1018, 2003.

2 KOMABA, S.; SASAKI, T.; KUMAGAI, N. Preparation and electrochemical performance of composite oxide of alpha manganese dioxide and $\mathbf{L i}-\mathbf{M n}-\mathbf{O}$ spinel. Eletrochimica Acta 50, p. 2297 - 2305, 2005.

3 ZHANG, W.; CHENG, Y. C.. Manganese metallurgy review. Part I: Leaching of ores/ secondary materials and recovery of electrolytic/chemical manganese dioxide. Hydrometallurgy 89, p. 137-159, 2007.

4 BROWNING, J. G.; DONNE W. S.. Electrochemical kinetic behaviour of the aqueous manganese dioxide electrode. Journal of Applied Electrochemistry 35:437-443, 2005.

5 SAMPAIO, A. J.;ANDRADE,M.C.;DUTRA,A.J.B. Rochas \& Minerais Industriais: Usos e Especificações. CETEM, Rio de Janeiro, Pág. 515 a 530, 2005. Disponível em http://www.cetem.gov.br/publicacao/CTs/CT2005-137-00.pdf. Acesso em Janeiro 2009.

6 RAYOVAC Material Safety Data Sheet, 2007. Disponível em $<$ http://www.rayovac.com>.Acesso em Ago. 2008.

7 SAYILGAN, E; KUKRER,T.; FERELLA, F.; VEGLIO, F.; KITIS, M. Reductive leaching of manganese and zinc from spent alkaline and zinc-carbon batteries in acidic media. Hydrometallurgy 97, 73-79, 2009

8 LI, J.;.LI,X.; HU, Q; WANG, Z.; ZHENG,J.; WU,L.; ZHANG,L. Study of extraction and purification of $\mathrm{Ni}, \mathrm{Co}$ and $\mathrm{Mn}$ from spent battery material. Hydrometallurgy 99, 7-12, 2009.

9 VATISTAS, N.; BARTOLOZZI, M.;ARRAS,S. The dismantling of the spent alkaline zinc manganese dioxide batteries and the recovery of the zinc from the anodic material. Journal of Power Sources. 101, 182-187,2001. 
10 ESPINOSA, D.C.R. Reciclagem de pilhas e baterias. 2008. 144p. Tese Escola Politécnica,, Universidade de São Paulo, São Paulo, 2008.

11 DNPM. Departamento Nacional de Produção Mineral. Balanço Mineral Brasileiro 2001. Disponível em < http://www.dnpm.gov. >. Acesso em Abril 2009.

12 LEE, J.D. Qímica Inorgânica não Tão Concisa. São Paulo: Edgard Blucher Ltda, , 2001. 527p.

13 GHAEMI, M.; GHOLAMI, A. MOGHADDAMB, R.B. A study around the improvement of electrochemical activity of $\mathrm{MnO}_{2}$ as cathodic material in alkaline batteries Electrochimica Acta 53, 3250-3256, 2008.

14 DUTRA, A.J.B; ALMEIDA, I.C.F. Efeito da densidade de corrente e temperatura na area superficial do dióxido de manganês eletrolítico. Revista Matéria, v. 11, n. 1, pp. $60-69,2006$.

15 LAURINDO, E. A ,FÁBIO,A.; SANTOS, M. L.; FERRACIN,L. C.; CARUBELLI, A.; $\mathrm{BOCCHI}$, N. FILHO,R.C.R. Produção de dióxido de manganês eletrolítico para uso em baterias de lítio. Quimca Nova, 22, 600,1999.

16 PAGNANELLI, F. SAMBENEDETTO C.; FURLANI, F.; VEGLI, L. TORO Preparation and characterisation of chemical manganese dioxide: Effect of the operating conditions. Journal of Power Sources 166, 567-577, 2007

17 JACOB, G. M.; ZHITOMIRSKY, I. Microstructure and properties of manganese dioxide films prepared by electrodeposition. Applied Surface Science, 254, 66716676, 2008.

18 PRÉLOT, B.; POINSIGNON,C.; THOMAS, F.; SCHOULLER,E.; VILLIÉRAS,F. Structural-chemical disorder of manganese dioxides 1. Influence on surface properties at the solid-electrolyte interface. Journal of Colloid and Interface Science 257, 77-84, 2003.

19 KIM, C.; AKASEA, Z.; ZHANGA, L.; HEUERA, A.; NEWMANB,A. E.; HUGHES, P. $J$. The structure and ordering of $\varepsilon-\mathbf{M n O}_{2}$. Journal of Solid State Chemistry 179 , 753-774, 2006. 
20 OWEN, M. P.; LAWRANCE,A.; DONNE S. W. An electrochemical quartz crystal microbalance study into the deposition of manganese dioxide. Electrochimica Acta 52 (2007) 4630-4639.

21 CLARKE, C. J; BROWNING, G. J; DONNE, S. W. An RDE and RRDE study into the electrodeposition of manganese dioxide. Electrochimica Acta 51 (2006) 57735784.

22 PAIK, Y.; BOWDEN,W.; RICHARD, T.; SIROTINA, R.; GREY, C.P. 2H MAS NMR and SPECS Studies of $\boldsymbol{\gamma}$-MnO2 Reduction in Zinc Alkaline Primary Batteries. Journal of The Electrochemical Society, 151, A998-A1011, 2004.

23 PISTOIA,G.; ANTONINI,A.; ZANE,A.; PASQUALI, M. Synthesis of Mn spinels from different polymorphs of MnO. Journal of Power Sources 56 (1995) 3743.

24 EULER, K. Battery Manganese Dioxide - A Survey of its History and Etymology. Journal of Power Sources 8, 133 - 141, 1982.

25 JOHNSON, C. S. Development and utility of manganese oxides as cathodes in lithium batteries. Journal of Power Sources 165, 559-565, 2007.

26. BRADY, E. J.; RUSSEL. W.J.; HOLUM,R. J. Química: A materia e suas transformações. Rio de Janeiro: Livros Técnicos e Científicos Editora S.A, 3.ed., 2003. 2V.406p,.

27 DELL, R.M. Batteries: fifty years of materials development. Solid State lonics, 134, 139-158, 2000.

28 BRODD, R.;BULLOCH,K.; LEISING, R. A.; MIDDAUGH, R. L.; MILLER, J. R.; TAKEUCHI, E. Batteries, 1977 to 2002. Journal of The Electrochemical Society, 151, K1-K11, 2004.

29 VELOSO, L. R. S.; RODRIGUES,L.O.C.;FERREIRA, D.A.; MAGALHÃES, F.S.; MANSUR, M. B. Development of a hydrometallurgical route for the recovery of zinc and manganese from spent alkaline batteries. Journal of Power Sources 152, 295-302, 2005. 
30 MACÊDO, M. I. F.; TRINDADE, R. B. E.; SOARES, P. S. M. Alternativas de processo hidrometalúrgico para reciclagem de pilhas domésticas usadas. XIX Encontro Nacional de Tratamento de Minérios e Metalurgia Extrativa. Recife, Pernambuco - 2002.

31 KOTZ, C.J.; TREICHEL,P. Jr. Química \& Reações Químicas. Rio de Janeiro: Livros Técnicos e Científicos Editora S.A. 1998.3 ed. 2V.730p

32. DOITPoMS- Dissemination of it for the Promotion of Materials Sciense. Disponível em < http://www.doitpoms.ac.uk/tlplib/batteries/index.php $>$ Acesso em Ago. 2009.

$33 \mathrm{QU}, \mathrm{D}$. Investigation of the porosity of electrolytic manganese dioxide and its performance as alkaline cathode material. Journal of Power Sources 156 692-699, 2006.

34 MALLOY, P; AARON; D. W. S. Surface characterisation of chemically reduced electrolytic manganese dioxide. Journal of Colloid and Interface Science, 320, 210-218, 2008.

35 BODOARDO, S; BRENET, J.; MAJA, M; SPINELLI, P. Electrochemical behaviour of $\mathrm{MnO}_{2}$ electrodes in sulphuric acid solutions. Electrochimica Acta, Vol. 39, No. 13, pp. 1999 2004, 1994.

36 BROWNING, J. G.; DONNE W. S. Electrochemical kinetic behaviour of the aqueous manganese dioxide electrode. Journal of Applied Electrochemistry 35:437-443, (2005).

37 KOZAWA, A; YEAGER, J.F. The Cathodic Reduction Mechanism of Electrolytic Manganese Dioxide in Alkaline Electrolyte. J.Electrochem.Soc 1115, 1003,1965

38 PISTOIA, G.; WIAUX, J.P.; WOLSKY. Used Battery Collection and Recycling. Industrial Chemistry Lirary, Volume 10, Elsevier, 2001.

39 PRAC - Programa de Responsabilidade Ambiental Compartilhada. Disponível em $<$ http://www.prac.com.br/download/pilhas baterias.pdf $>$ Acesso em Novembro 2009 
40 BERNARDES, A.M; ESPINOSA, D.C.R.; TENÓRIO J.A.S. Recycling of batteries: a review of current processes and technologies. Journal of Power Sources 130, 291-298, 2004.

41 BARTOLOZZI, M. The recovery of metals from spent alkaline manganese batteries: a review of patent literature. Resources, Conservation and Recycling, 4, 233-240, 1990.

42 RABAH, M.A; FARGHALY, F.E; MOTALEB, M.A. ABD-EL. Recovery of nickel, cobalt and some salts from spent Ni-MH batteries. Waste Management 28, 11591167, 2008.

43 CONTESTABILE, M.; PANERO, S.; SCROSATI, B. A laboratory-scale lithium-ion battery recycling process. Journal of Power Sources 92, 65-69, 2001.

44 SALGADO, A. L.; VELOSO, A. M.O. PEREIRA, D. D. Recovery of zinc and manganese from spent alkaline batteries by liquid-liquid extraction with Cyanex 272. Journal of Power Sources, 115, 367-373, 2003.

45 FRÖHLICH, S.; SEWING, D.. The BATENUS process for recycling mixed battery waste. Journal of Power Sources 57, 27-30, 1995.

46 SOUZA, C. C. B. M., TENÓRIO, J. A. S.Simultaneous recovery of zinc and manganese dioxide from household alkaline batteries through hydrometallurgical processing. Journal of Power Sources 136 (2004) 191-196

47 AFONSO, J. C.; BARANDAS,A.P.M.G.; SILVA, G. A. P.; FONSECA, S. G. Processamento da pasta eletrolítica de pilhas usadas. Quim. Nova, Vol. 26, No. 4, 573-577, 2003.

48 WOLFF, E.; SCHWABE,W. K.; LANGE, L. C.; SANTANA, D. W.E. A.; DUTRA, A. $\mathrm{T}$. A utilização de pilhas zinco-carbono e alcalina de manganês na produção de agregado leve. XXVII Congresso Interamericano Ingenieria Sanitaria y Ambiental Cancúm, México, 27 al 31 de octubre, 2002.

49 CHEMETAL. Disponível em <http://www.chemetal.cn/eletrolytic-manganesedioxide.htm> Acesso em Ago. 2008. 
50 ZHANG, W.; CHENG, Y. C.. Manganese metallurgy review. Part II: Manganese separation and recovery from solution. Hydrometallurgy 89, p. 160-177, 2007.

51 FERNANDES, J. B; DESAI, B. D; DALAL, V. N. K. Manganese Dioxide - a review of a battery chemical part $i$. chemical syntheses and $x$-ray diffraction studies of manganese dioxides. Journal of Power Sources, 15, 209 - 237, 1985.

52 MORITA, M.; IWAKURA, C.; TAMURA, H. The anodic characteristics of manganese dioxide electrodes prepared by thermal decomposition of manganese nitrate. Electrochimica Acta, 22, 325 -328, 1997.

53 RAGHAVAN, R., UPADHYAY, R.N. Innovative hydrometallurgical processing technique for industrial zinc and manganese process residues. Hydrometallurgy 51 (2), 207-226. 1999.

54 KHOLMOGOROV, A.G.; ZHYZHAEV, A.M.; KONONOV, U.S.; MOISEEVA, G.A.; PASHKOV, G.L. The production of manganese dioxide from manganese ores of some deposits of the siberian region of russia. Hydrometallurgy 56, 1-11, 2000.

55 RETHINARAJ, J. PRABHAKAR ; VISVANATHAN S. Preparation and properties of electrolytic dioxide manganese -Review. Journal of Power Sources, 42, 335343,335, 1993.

56 ARSDALE, G. D. Van. Hidrometalurgia de metales comuns. . México: Union Tipografia Editorial Hispano Aericana, 1965.

57 RODRIGUES, S.; MUNICHANDRAIAH, N; SHUKLA ,A. K. A cyclic voltammetric study of the kinetics and mechanism of electrodeposition of manganese dioxide .Journal of applied electrochemistry 28, 1235-1241, 1998.

58 GHAEMI, M. BIGLARI,Z. BINDER, L. Effect of bath on electrochemical properties of the anodically deposited manganese dioxide. Journal of Power Sources, 103, 29-34, 2001

59 PREISLER, E. Electrodeposited manganese dioxide with preferred crystal growth. Journal of applied electrochemistry 6, 301-3 I0, 1976. 
60 GHAEM, M.; BINDER, L Effects of direct and pulse current on electrodeposition of manganese dioxide. Journal of Power Sources 111, 248-254, 2002.

61 TAKAHASHI, K. Dry cell and battery industry and powder technology with emphasis on powdered manganese dioxide. Electrochimica Acta, Vol.26, № 10, $1467-1476,1981$.

62 RETHINARAJ, J. P.; VISVANATHAN,S. Anodes for the preparation of EMD and application of manganesedioxide coated anodes for electrochemicals. Materials Chemistry and Physics, 27 (1991) 337-349 337

63 PREISLER, E. Growth of electrodeposited y-manganese dioxide from a suspension bath. Journal of Applied Electrochemistry 19 (1989) 540-546.

64 PILLA, A. S.; DUARTE, M. M.E; MAYER, C. E. Manganese dioxide electrodeposition in sulphate electrolytes:the influence of ferrous ions.Journal of Electroanalytical Chemistry 569 (2004) 7-14.

65 PAUL, R.L.; CARTWRIGHT, A. The mechanism of the deposition of manganese dioxide part III. rotating ring-disc studies. J Electroanal. Chem., 201 (1986) 123-131

$66 \mathrm{KAO}, \mathrm{W}$.; WEIBEL, V. J; ROOT, M.J. The Influence of Potassium Ion on the Electrodeposition and Electrochemistry of Electrolytic Manganese Dioxide. J. Electrochem. Soc., Vol. 139, No. 5, May 1992.

67 KOZAWA, A.; VOSBURGH, W. C. The Relation of the Conditions of Electrodeposition of Manganese Dioxide to the Discharge Characteristics. Journal of the Electrochemical Society, 105, $59-63,1958$

68 ERA, A.; TAKEHARA, Z.; YOSHIZAWA, S. Influence of impurities especially lead contained in manganese dioxide upon the self-discharge of the leclanche dry cell. Electrochimica Acta. Vol. 13, 383 - 396, 1968.

69 Resolução No 257 do Conselho Nacional do Meio Ambiente (CONAMA), de 30/06/1999, Diário Oficial da União, 22/07/1999. Disponível em http://www.cntdespoluir.org.br. Acesso em novembro 2009 
70 LI, W.S.; JIANG, L.C.; HUANG, Z.T. Preparation of manganese dioxide using $\mathrm{Ag}^{+}$ions as an electrocatalyst. Journal of Power Sources 69, 81- 87, 1997.

71 PAIXAO, J.M.M., Amaral, J.C.; Memoria, L.E.; Freitas, L.R. Sulfation of Carajas manganese ore. Hydrometallurgy $39,215-222,1995$.

72 VOGEL, A. I., Química Analítica Qualitativa. 5 Ed.. São Paulo. Editora Mestre Jou, 1981.665p.

73 AMARAL, A. F. Propriedades estruturais e eletroquímicas de espinélio de lítio e manganês dopados para uso em baterias de lítio. 2005. 194 p Tese (Doutorado). Universidade Federal de São Carlos,São Paulo,2005.

74 MATSUKI, k. ; ENDO, T.; KAMADA,H. SEM studies of electrolytic manganese dioxide. Electrochimica Acta, 29, 983 - 993, 1994.

75 TOSOH. Disponível em http://www.tosoh.com/Products/tcgmag.htm. Acesso em Julho 2009.

76 TRONOX. Disponível em http://www.tronox.com/products/ otherproducts/ electromanganese.htm. Acesso em Julho 2009.

77 DAVIS, S. M., BOWDEN, W. L., RICHARDS, T. C. Defining high power EMD through porosimetry. Journal of Power Sources 139, 342-350, 2005.

78 TAMURA, H.; ISHIZEKI, K.; NAGAYAMA, M.; FURUICHI, R. Incorporation of impurity metal ions in electrolytic manganese dioxide. J. Electrochem. Soc. 8, 141,1994

79 DESAI, B. D; FERNANDES, J. B; DALAL, V N K. Manganese Dioxide - a review of a battery chemical part II. solid state and electrochemical properties of manganese dioxides chemical. Journal of Power Sources, 16, 1-43, 1985.

80 PAUL, R.L.; CARTWRIGHT, A. The mechanism of the deposition of manganese dioxide part II.Electrode impedance studies. J Electroanal. Chem., 201 (1986) 113-122. 